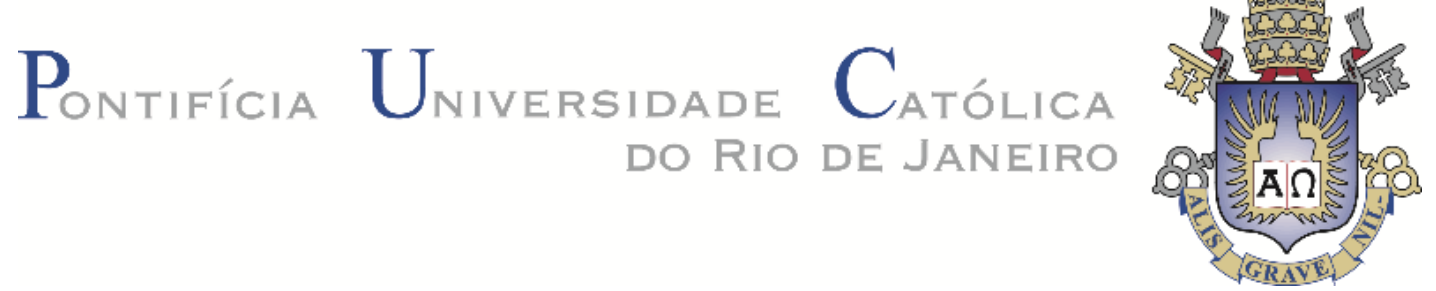

Erica Pereira dos Santos Nascimento

\title{
A CONTRIBUIÇÃO DOS SABERES-FAZERES NA TRAJETÓRIA DE JOVENS ATIVISTAS GONÇALENSES
}

\section{Dissertação de Mestrado}

Dissertação apresentada ao Programa de Pósgraduação em Educação da PUC-Rio como requisito parcial para obtenção do grau de Mestre em Educação.

Orientadora: Prof. ${ }^{\text {a }}$ Vera Maria Candau 


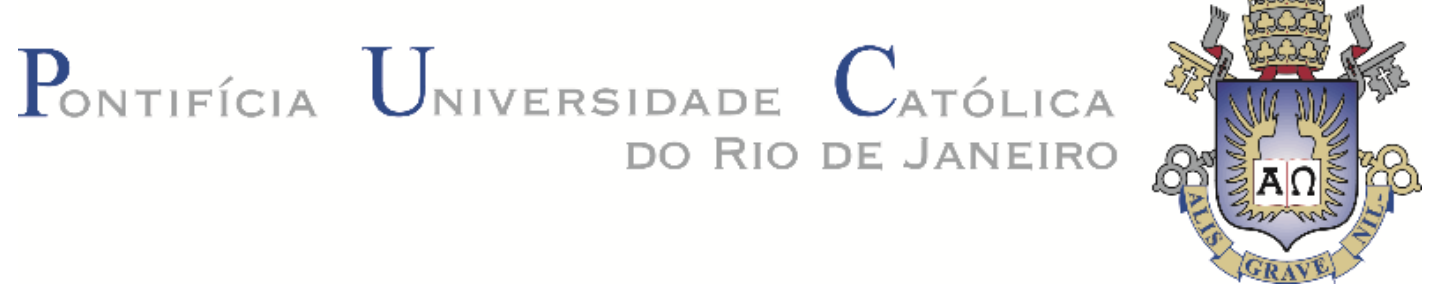

Erica Pereira dos Santos Nascimento

A contribuição dos saberes-fazeres na trajetória de jovens ativistas gonçalenses

Dissertação apresentada como requisito parcial para obtenção do grau de Mestre pelo Programa de Pósgraduação em Educação do Departamento de Educação do Centro de Teologia e Ciências Humanas da PUC-Rio. Aprovada pela Comissão Examinadora abaixo assinada.

\author{
Prof. ' Vera Maria Candau \\ Orientadora \\ Departamento de Educação - PUC-Rio \\ Prof.- Maria Luiza Oswald \\ UERJ
}

Prof. Renato Pontes

Departamento de Educação - PUC-Rio

Prof ${ }^{\mathrm{a}}$. Monah Winograd

Coordenadora Setorial do Centro de Teologia e Ciências Humanas

PUC-Rio

Rio de Janeiro, 25 de fevereiro de 2021 
Todos os direitos reservados. É proibida a reprodução total ou parcial do trabalho sem autorização da universidade, do autor e do orientador.

\section{Erica Pereira dos Santos Nascimento}

Graduou-se em Pedagogia pela Pontifícia Universidade Católica do Rio de Janeiro em 2015. Tem experiência docente no Ensino Fundamental I e II. Participou do Programa de Intercâmbio Acadêmico na Universidad Autônoma de Madrid Espanha (2014). Foi membro do Grupo de Estudos sobre o Professor e o Ensino da PUC-Rio (GEPPE). Atualmente é integrante do Grupo de Estudo sobre Cotidiano, Educação e Culturas da PUC-Rio (GECEC).

Ficha Catalográfica

Nascimento, Erica Pereira dos Santos

A contribuição dos saberes-fazeres na trajetória de jovens ativistas gonçalenses / Erica Pereira dos Santos Nascimento; orientadora: Vera Maria Candau. -2021.

146 f. : il. color. ; $30 \mathrm{~cm}$

Dissertação (mestrado)-Pontifícia Universidade Católica do Rio de Janeiro, Departamento de Educação, 2021.

Inclui bibliografia

CDD: 370 
A todos/as que me provocam a ideia de constante (des)aprendizagem, especialmente às crianças e jovens que encontrei ao longo dos meus 35 anos de vida. 


\section{Agradecimentos}

Este trabalho é fruto de muitas histórias e entremeios. Dessa forma, agradeço profundamente a Deus pelos encontros proporcionados. Sejam os encontros comigo mesma onde encontrei persistência, sejam os encontros com tantos outros e outras que motivam minhas "insistências".

Agradeço a meus pais, especialmente a minha mãe dona Esoir, por sua força e dedicação. Seu cuidado, sensibilidade e apoio ao estudo me deram gosto pela leitura que liberta e fortifica à luta pelos direitos das mulheres.

Ao meu amigo e companheiro Rodrigo Costa, pelo amor que cuida e pelas risadas que descuidam. Obrigada por tudo e sempre.

Aos meus sobrinhos Lucas e João Pedro pelas alegrias e descobertas partilhadas.

À todos os meus ex-alunos e ex-alunas pelas participações nas aulas. Obrigada por me colocaram em contato com o exercício da escuta, criatividade e criticidade. Nossos encontros e diálogos foram fundamentais para que minha formação estivesse sempre em movimento.

À s amigas Aline Farias, Ediléa Carvalho, Rachel Romano, Tatiane Fendeler e Thaís Truppel com quem divido afinidades, angústias e realizações. Gratidão!

Aos jovens que "constroem a manhã desejada" em suas cidades, becos e favelas. Em especial aos jovens gonçalenses do Projeto Ressuscita São Gonçalo que trabalham na e pela cidade da qual sou cria. Obrigada rede linda!

À minha orientadora, professora Vera Candau, pelo acolhimento, orientações e incentivos. A admiração por seu trabalhou somou-se a admiração por sua humanidade forjada em palavras ânimo, resistência e insurgência.

Ao GECEC, grupo de pesquisadores e pesquisadoras de retaguarda, obrigada por compartilharem conhecimentos e esperanças. Nossos encontros de denúncia e anúncio foram verdadeiras pedagogias decoloniais.

Ao professor Renato Pontes, por suas aulas, dinâmicas, amizade, conselhos e encorajamento. Tudo junto e misturado como acontece nos enlaces da vida. Sua companhia é sabida e bem humorada. Uma espécie rara de "voz da consciência" que estimula a confiar no processo.

À professora Maria Luiza Oswald pela leitura e contribuições para o trabalho, enquanto membro integrante da banca de avaliação desta dissertação de mestrado. Que também se dedica ao tema das juventudes.

À professora Rita de Oliveira pelo acolhimento e escuta atenta. "Seu olhar melhora o meu".

À PUC- Rio e ao CNPq pela oportunidade e auxílio concedido. O presente trabalho foi realizado com apoio da Coordenação de Aperfeiçoamento de Pessoal de Nível Superior - Brasil (CAPES) - Código de Financiamento 001. 
Ao PPGE/PUC-Rio, seus colaboradores/as, professores/as com especiais recordações do convívio com a inteligência do professor Marcelo Andrade (in memoriam).

À minha turma de mestrado pelos exemplos de humanidade na realização do trabalho acadêmico. Nomeadamente a resiliência de Alda Siqueira, Bernardo Padula, Clara de Melo, Francielen dos Santos, Grazielle Frota, Isabella Magalhães, Manuela Gril, Mariana Muniz, Nathália Rebouças, Talita de Oliveira, Tatiane Rodrigues e Vitória Godin,

À Ana Luiza Honorato, Valéria Martins, Paula Araújo, e Victória Guimarães com quem dividi os dias de escrita da dissertação e a utopia de dias melhores em que a justiça social (e a vacina) seja uma realidade e não mais algo pelo que se lutar. 


\section{Resumo}

Nascimento, Erica Pereira dos Santos; Candau, Vera Maria. A contribuição dos saberes-fazeres na trajetória de jovens ativistas gonçalenses. Rio de Janeiro, 2021. 146p Dissertação de Mestrado - Departamento de Educação, Pontifícia Universidade Católica do Rio de Janeiro.

Esta pesquisa objetiva evidenciar trajetórias e processos que motivam participação e engajamento social de jovens na atualidade. Considerando recentes denúncias e anúncios das juventudes contemporâneas, este estudo se justifica diante da necessidade de compreensão e fortalecimento da participação juvenil na construção de novos caminhos para o planeta que enfrenta desgaste político, humanitário e geográfico. Tendo como objeto de estudo narrativas de jovens ativistas que se fazem presentes no projeto "Ressuscita São Gonçalo", a pesquisa buscou identificar, descrever e compreender processos formativos que constituem seus engajamentos. Existiria, portanto, algo de particular na trajetória desses jovens? A dissertação aproximou os estudos sobre Juventudes, Interculturalidade, Decolonialidade e Epistemologias do Sul, especialmente, na perspectiva de pedagogia e do pedagógico defendido por Walsh (2016) ao assumir o lugar do vivido e experimentado para mapear a tessitura da emancipação social emergente em processos cotidianos. $\mathrm{O}$ desenvolvimento da pesquisa aliou observação de atividades lideradas pelos jovens a entrevistas sob a forma de entrevista compreensiva. Nesta abordagem as narrativas juvenis assumem centralidade em vias de visibilizar saberes e fazeres enunciados por eles. Emerge deste mapeamento plurivocal a produção de significados advindos de memórias afetivas e reinterpretações propositivas com e para a periferia. Os resultados mostram a importância das experiências sociais como fomento político para o debate democrático. Destaca-se a responsabilização pelo território somada a esperança por um novo tempo como um chamamento de força e despertar para um giro entre resistir ao descaso que subalterniza e insurgir em práticas e ações de ressignificação das realidades experimentadas.

\section{Palavras-chave}

Juventudes; Participação social; Interculturalidade Crítica; Ecologia de Saberes. 


\section{Abstract}

Nascimento, Erica Pereira dos Santos; Candau, Vera Maria Ferrão (Advisor). The contribution of know-how in the trajectory of young activists in São Gonçalo/RJ. Rio de Janeiro, 2021. 146p. MSc. Dissertation - Departamento de Educação, Pontifícia Universidade Católica do Rio de Janeiro.

This research highlights trajectories and processes that motivate participation and social engagement of young people today. Considering recent complaints and announcements by the contemporary youth, this study is justified by the need to understand and strengthen youth participation in the construction of new paths for the planet that faces political, humanitarian and geographical distress. The research, whose objects of study are the narratives of young activists from the project "Ressuscita São Gonçalo", seeks to identify, describe and understand the training processes that constitute their engagements. What was different about the trajectory of these young people? The dissertation approaches studies on Youth, Interculturality, Decoloniality and Epistemologies of the South, especially in the perspective of pedagogy defended by Walsh (2016) when taking the place of the lived and experienced to map the fabric of the emerging social emancipation in everyday life. The research combines observation of activities led by young people and comprehensive interviews so youth narratives take center stage in the process of making knowledge and actions enunciated by them visible. The production of meaning from affective memories and propositional reinterpretations with and for the periphery emerges from this plurivocal mapping. The results show the importance of social experiences as a political stimulus for the democratic debate. Emphasis is placed on accountability for the territory as well as the hope for a new time as a call for strength and awakening to a turn between resisting the neglect that subordinates and insurgency in practices and actions to re-signify the experienced realities.

\section{Keywords}

Youths; Social participation; Critical Interculturality; Ecology of Knowledge. 


\section{Sumário}

1 Introdução 16

1.1 De São Gonçalo para a universidade: construção do objeto de pesquisa

1.2 Inquietações e objetivos deste trabalho 18

1.3 Composição da dissertação 24

2 Juventudes, trajetórias e ativismo 26

2.1 Jovens e envolvimento sociopolítico na história recente 26

$\begin{array}{ll}2.1 .1 & 31\end{array}$

2.1.2 Engajamentos juvenis e novas formas de participação 35

$\begin{array}{ll}2.2 \text { Ativismos juvenis } & 37\end{array}$

3 Decolonialidade, Interculturalidade, processos educativos e ativismos juvenis

3.1 Educação, resistências e mobilizações 46

3.2 Processos formativos e interculturalidade $\quad 50$

3.3 Engajamentos para impulsionar lógicas outras 54

4 Fala e escuta das juventudes gonçalenses: metodologia da pesquisa

4.1 Etapas e processos da pesquisa: aproximação do campo 58

4.1.2 Ânimo e mãos à obra no e para o trabalho de campo 62

4.1.2.1 Observação 63

4.1.2.2 Questionário 65

4.1.2.3 Entrevista 68

4.2 Análise do material $\quad 71$

5 Fala juventude: análise e discussão dos resultados $\quad \mathbf{7 4}$

5.1 Notas das observações $\quad 74$

5.1.1 Aproximação 75

5.1.2 Estreitando inquietudes $\quad 82$

5.1.3 Desafio do encontro 86

5.2 No embalo, "Ressuscita São Gonçalo" e Casa Fluminense 87

5.3 Dados do questionário $\quad 99$

5.4 Dados das entrevistas $\quad 100$

5.4.1 Perceber-se nas incertezas 102

5.4.2 Encontros com a diversidade 107

5.4.3 Perspectivas em ação 113

5.4.4 Microuniversos insurgentes 118

6 Considerações finais 124

$\begin{array}{ll}7 \text { Referências bibliográficas } & 129\end{array}$

8 Apêndices 136

8.1 Apêndice 1- Termo de Consentimento Livre e Esclarecido 136 
8.2 Apêndice 2-Questionário 138

8.3 Apêndice 3 - Roteiro de observação 140

8.4 Apêndice 4 - Roteiro da entrevista com os/as jovens 141

8.5 Apêndice 5 - Roteiro da entrevista com representante da ONG Casa

Fluminense 143

9 Anexos 144

9.1 Anexo 1 - Parecer da Comissão de Ética em Pesquisa da PUC-Rio $017 / 2020$

9.2 Anexo 2 - Documento Modelo para Pesquisa elaborado pelos/as jovens. 


\section{Lista de figuras}

Figura 1 - Exemplo de pergunta obrigatória do questionário online desta $\begin{array}{ll}\text { pesquisa } & 66\end{array}$

Figura 2 - Área da Praia da Pedrinhas, Boa Vista São Gonçalo. $\quad 76$

Figura 3 - Desafio do Lixo, edição abril/2019. 77

Figura 4 - Desafio do Lixo, edição abril/2019. 78

Figura 5 - Desafio do Lixo, edição fevereiro/2020. 79

Figura 6 - Desafio do Lixo, edição fevereiro/2020. 80

Figura 7 - Desafio do Lixo, edição fevereiro/2020. 81

Figura 8 - Material de divulgação do Laboratório de Análise Covid-19, julho/2020.

Figura 9 - Dados a partir de consulta pública - Ressuscita São Gonçalo/2019.

Figura 10 - Dados a partir de consulta pública - Ressuscita São $\begin{array}{ll}\text { Gonçalo/2019. } & 90\end{array}$

Figura 11 - Representação dos bairros em que residem os entrevistados 


\section{Lista de abreviatura ou siglas}

Art. - Artigo

CAPES - Coordenação de Aperfeiçoamento de Pessoal de Nível Superior

CEDERJ - Centro de Educação Superior a Distância do Estado do Rio de Janeiro

CNPq - Conselho Nacional de Desenvolvimento Científico e tecnológico

COVID-19 - Coronavirus disease 2019 (traduzido para a língua

portuguesa como "doença por coronavírus 2019"

CVV - Centro de Valorização da Vida

ECA - Estatuto da Criança e do Adolescente

ENEM - Exame Nacional do Ensino Médio

Fiocruz - Fundação Oswaldo Cruz

GT - Grupo de Trabalho

GECEC - Grupo de Estudos sobre Cotidiano, Educação e Cultura(s)

IBGE - Instituto Brasileiro de Geografia e Estatística

M/C - Modernidade/Colonialidade

OMS - Organização Mundial de Saúde

ONG - Organização não-governamental

ONU - Organização das Nações Unidas

ONU- Habitat - Programa das Nações Unidas para os Assentamentos

Pibid - Programa Institucional de Bolsas de Iniciação à Docência

PNJ - Plano Nacional da Juventude

PUC- Rio -Pontifícia Universidade Católica do Rio de Janeiro

RBE - Revista Brasileira de Educação

RJ - Rio de Janeiro

SG - São Gonçalo

TICs - Tecnologias da Informação e Comunicação 
UERJ - Universidade do Estado do Rio de Janeiro

UFF - Universidade Federal Fluminense

UFRJ - Universidade Federal do Rio de Janeiro

UFRRJ - (Universidade Federal Rural do Rio de Janeiro 


\section{Lista de quadros}

Quadro 1 - Jovens do Projeto Ressuscita São Gonçalo declaram participação nos encontros de planejamento e tomada de decisões 
"Não sou esperançoso por pura teimosia, mas por imperativo existencial e histórico" Paulo Freire

"O olho vê, a lembrança revê, e a imaginação transvê.

É preciso transver o Mundo" Manuel de Barros 


\section{Introdução}

Eu acredito é na rapaziada Que segue em frente e segura o rojão (Como é que não?)

Eu ponho fé é na fé da moçada Que não foge da fera e enfrenta o leão

(E vamos à luta - Gonzaguinha)

Esta pesquisa analisa trajetórias e os processos formativos de jovens lideranças da cidade de São Gonçalo, um município que possui a $2^{\mathrm{a}}$ maior população do Estado do Rio de Janeiro ${ }^{1}$. Compõem este estudo 11 indivíduos entre 22 e 45 anos de idade, de origem periférica, que atuam com e para seu território e comunidade de origem, a partir do projeto social "Ressuscita São Gonçalo". O objetivo é conhecer, compreender e visibilizar os caminhos, as resistências, as desnaturalizações e as proposições que sensibilizaram e guiaram essas lideranças para o engajamento e participação social.

\subsection{De São Gonçalo para a universidade: construção do objeto de pesquisa}

O interesse pela temática surgiu de reflexões no convívio com a juventude na cidade de São Gonçalo, região metropolitana do estado do Rio de Janeiro. A este fator, soma-se a trajetória acadêmica em reflexões fomentadas pela literatura adotada no âmbito de participação no Grupo de Estudos sobre Cotidiano, Educação e Cultura (as), GECEC-PUC/Rio.

Mulher, residente em São Gonçalo, bolsista em programa institucional universitário e primeira da família a ingressar no ensino superior. São algumas das configurações que incidem sobre minha posição e atuação como profissional da Educação. O trabalho pedagógico e o cotidiano com crianças e jovens invariavelmente reconectam minha origem e trajetória, especialmente, a infância e juventude das classes sociais populares.

1 De acordo com dados do IBGE, São Gonçalo é a cidade com 2a maior população residente do Estado do Rio de Janeiro com aproximadamente 999.728 (novecentos e noventa e nove mil setecentos e vinte oitos) habitantes. https://cidades.ibge.gov.br/brasil/rj/sao-goncalo/pesquisa/23/25207?tipo=ranking. Acessado em 18 jan. 2020. 
Entre ser e reconhecer-se nas lutas cotidianas presentes nas aglomerações urbanas $^{2}$ e no eixo favela/asfalto ${ }^{3}$, cresci confrontando impertinências e inadequações da administração pública no bairro em que moro. Apoio e suporte para uma vida digna ou viriam via troca de favores com e para os representantes do Estado, ou não viriam.

$\mathrm{Na}$ juventude, por vias da religiosidade, aproximei-me das propostas da Pastoral da Juventude em suas denúncias e movimentos. "Ver, julgar e agir" em consonância com a Doutrina Social da Igreja Católica colaboraram no meu reconhecimento sobre lutas e resistências ético-políticas imprescindíveis para a garantia da vida digna a qual todos temos direito. $\mathrm{O}$ contato com essas proposições, espaços e entusiastas militâncias trouxeram sentido a prática educativa na dinâmica e promoção dos Direitos Humanos na qual me posiciono.

Por ocasião do ingresso no curso de Pedagogia, em 2011 fui promovida de Auxiliar de Secretaria à Professora na escola em que trabalhava em São Gonçalo. Permaneci exercendo o magistério na instituição até 2013, quando alcancei bolsa de estudos no programa da Universidade e realizei intercâmbio acadêmico no exterior. Em 2015 retornei ao trabalho em sala de aula. Dessa vez na cidade do Rio de Janeiro, especificamente na zona sul com estudantes das regiões da Rocinha, Vidigal, Horto, Cruzada São Sebastião e Rio das Pedras, onde lecionei até 2019.

Quando em sala de aula, atividades e discussões fomentadas para a Educação em Direitos Humanos nos componentes "Ética e Cidadania" e "Ética e Valores" objetivavam colaborar em sensibilização e reflexão sobre dignidade humana. Temas como cidadania, desigualdades sociais, descaso com a diversidade racial, religiosa, gênero e de classe, complacência social com a corrupção e concessão de privilégios, a solidificação do sistema familiar patriarcal e machista, como a crescente onda de individualismos decorrentes da falsa ideia de "modernidade" fizeram parte da minha formação e posteriormente das discussões feitas com as crianças na minha prática pedagógica.

Em certo sentido, a fragmentação do tempo escolar não colaborava com o interesse dos estudantes frente as temáticas abordadas nos componentes citados.

2 Organização de território conforme dados do Instituto Brasileiro de Geografia e Estatísticas.

3 A utilização do termo pretende visibilizar as realidades, reinvindicações e resistências presentes neste espaço urbano. Tem se em conta a participação dos jovens na cidade e o entrecruzamento das linhas invisíveis de cá e de lá que separam as realidades abissais globais (SANTOS, 2007). 
Não foram poucas as vezes em que o corredor se tornava espaço estendido às narrativas inquietas a partir daquelas reflexões e percepções. Por esses diálogos grande parte dos estudantes avaliavam como positiva a dinâmica apresentada nos planejamentos e compartilhavam sobre seus engajamentos de "ética e valores" no cotidiano de seus becos e bairros. Neste movimento de ensinar/aprender do cotidiano escolar é que me surgiram inquietações sobre a juventude contemporânea e suas formas de compromisso e questionamento de desigualdades sociais globais que fendem suas realidades locais.

Dessa forma, alinhavei as observações realizadas em sala de aula à temática da juventude brasileira contemporânea em crescentes formas de participação social. Assim, iniciou-se meu percurso na pesquisa de mestrado de onde emergiram questionamentos sobre quem ou o que estaria educando a juventude para tais engajamentos; indago também quais experiências sensibilizam a juventude engajada para os compromissos que assumem.

\subsection{Inquietações e objetivos deste trabalho}

Iniciei esta pesquisa realizando uma revisão bibliográfica lançando mão de revistas qualificadas A1 e A2, conforme critérios do Qualis Periódicos, seguido de buscas no Catálogo de Teses e Dissertações da CAPES. Comecei minha busca utilizando um filtro com as seguintes palavras-chaves: juventudes, trajetória de vida, liderança, ativismo jovem, protagonismo jovem e mobilização social. Em seguida, procurei por produções cuja temática compreendesse ou relacionasse engajamento e ativismo em movimentos sociais e/ou coletivos e/ou formação das identidades juvenis e suas percepções sobre o mundo multicultural, assim como lideranças juvenis em contextos político-sociais. Examinei produções que fizessem referência às juventudes contemporâneas e seus processos de participação democrática e coletiva. Dessa maneira, considerando o volume de trabalhos encontrados, foi possível identificar forte preocupação com a temática tornando substancial para mim a discussão entre juventude, engajamento e debate democrático.

Neste campo, ocorre também a intensificação de mobilizações, atos e protestos que têm endossado pautas de questões historicamente silenciadas, como 
as questões de gênero, orientação sexual, étnicas, entre outras. A partir dessas ocorrências, a pluralidade presente nas pautas chama atenção para a forma como a diversidade é tratada. Em grandes e pequenos atos, a forma como a juventude tem se posicionado, tem deixado marcas e proposições de visibilidade às bandeiras que hasteiam. Denúncias e requerimentos que "nos colocam diante da realidade histórica do continente, marcada pela negação do "outro", física ou simbólica, ainda presente nas sociedades latino-americanas" (CANDAU; RUSSO, 2010, p. 154).

Esclareceu-se, conforme as reflexões de Leite (2017), que o ativismo político representativo a partir da juventude cresce e multiplica-se no país. Novos horizontes na ordem social que "trazem aspectos das relações entre juventude e cidade que vão além da presença física do ativismo político (LEITE, 2017, p. 179). A utilização das redes sociais virtuais supera limites geográficos em sua comunicação e contribui com demonstração de maturidade política das juventudes que "subvertem o adultocentrismo que tende a prevalecer nas organizações sociais" (p.183).

De acordo com Gonh (2018), os jovens refutam a velha política e ressignificam a relação entre ser militante e ativista. Dessa forma, atuam de forma coletiva, com novos repertórios e linguagens, em cultura própria e múltiplos processos de subjetivação. A juventude enquanto produtora político-cultural vem ocupando espaços e realçando a intrínseca relação entre participação político-social e educação-emancipação.

As subversões das juventudes e a insurgência de movimentos entre praças e escolas tornam-se caminho de apropriação das discussões do campo democrático. Leite e Araújo (2018) apresentam narrativas juvenis de convergência a críticas ao sistema escolar "que tende a priorizar o individualismo e não parece investir na construção do pertencimento e da responsabilidade social" (p.101). Contudo, os jovens optam por ocupar e não abandonar. Contestam a ordem dominante e apresentam-se comprometidos a equacionar igualdade e diferença de forma política e coletivamente (LEITE e ARAÚJO, 2018).

Chamou atenção o levantamento de trabalhos da Revista Brasileira de Educação (RBE), realizado por Sposito e Tarábola (2017), cuja análise situa a importância de fomentar pesquisas que percebam a juventude fora do viés aluno/estudante. Como sugere Sposito; Almeida e Carrochano (2020), investigar tendências do campo para novas interpretações sobre continuidades e descontinuidades, fluxos e refluxos de uma geração de ativismos que pauta para 
além das questões juvenis, territoriais e sociais como representação política na democracia participativa.

Outrossim, tais mobilizações e seus atores têm se posicionado pela necessidade de inclusão social evidenciando as diferenças como riqueza (CANDAU, 2016a). Não tendo, portanto, como negar o caráter educativo do ato político nem a natureza política dos processos educativos.

Ao longo da revisão percebi espaço para um estudo que investigasse, compreendesse e visibilizasse processos formativos de engajamentos juvenis que se fazem presentes em iniciativas e coletivos nas periferias das cidades. Protagonismos e lideranças desencadeados em territórios e movimentos populares de cunho político-social, como por exemplo, as trajetórias dos participantes do trabalho de Loureiro (2019) que atuam no movimento de hip hop em São Paulo e se "dedicam a atividades direcionadas às populações de seus bairros e da periferia urbana em geral" (p.5). Igualmente as narrativas insurgentes identificadas no trabalho de Izaú (2017) que traz horizontes de lutas e resistências da juventude mineira pelo direito e percursos seguros nos transportes públicos da cidade.

Vozes, corpos e histórias que se colocam em perspectivas de ação que (re)dimensionam protestos e movimentos que repercutem em diferentes Estados e cidades brasileiras. Assim, a justificativa do enfoque desta investigação, que visa reconhecimento e afirmação dos saberes-fazeres na trajetória de jovens ativistas, encontro nos trabalhos de Candau (2014, p.55) que afirma que no debate acadêmico entre movimentos sociais, educação e interculturalidade, existe a necessidade de avançar para que formas outras de pensar e, especialmente, de (re)agir auxiliem na (re)construção da sociedade. Segundo a autora um dos principais desafios para o campo prático e teórico seria a construção e socialização de "práticas pedagógicas de educação intercultural" (CANDAU, 2014, p. 55).

Ações e práticas que aqui defendemos a partir da perspectiva de Walsh (2016) que enxerga pedagogia em experiências e histórias "desde abajo". Trata-se dos caminhos biográficos e pedagógicos, especialmente das juventudes, que desejamos investigar. Caminhos pedagógicos que serão considerados, não como unidade social ou parte de um momento da vida, mas como os diversos conhecimentos e aprendizagens a partir dos gritos que ecoam no e do Sul Global, ou seja, das histórias subalternizadas, implicando na valorização de experiências de movimentos e ativistas, e, assim, "chamar e atenção sobre sua existência e crescente 
insurgência" (WALSH, 2016, p. 73). Gritos que questionam a precariedade e a indiferença com a qual a população é submetida, gritos comprometidos com a liberdade individual e coletiva traduzidos como afirmação democrática. Afinal, quais experiências levam os jovens a questionar a forma atual de se fazer política e envolverem sua juventude na intenção de construir uma nova perspectiva da história de seus territórios e cidades?

O Projeto "Ressuscita São Gonçalo”, desenvolvido na cidade de São Gonçalo, região metropolitana do Estado do Rio de Janeiro, tem por lema "Vamos juntos reconstruir nossa cidade" e se dispõe a ouvir a população gonçalense, diagnosticar, articular e estruturar objetivos e metas realizáveis para os governos estaduais e municipais efetivarem nos próximos 10 anos. A elegibilidade das lideranças do "Ressuscita São Gonçalo" para esta investigação se dá por conta de sua inserção com e para a cidade.

O referido projeto é resultado do engajamento de jovens que reuniram seus ideais político-sociais e os submeteram ao edital "Agenda Rio 2030" 4 , lançado pela $\mathrm{ONG}^{5}$ Casa Fluminense, em 2018. A Casa Fluminense é uma organização nãogovernamental que atua na defesa de uma agenda pública voltada universalmente a todo território e população da região metropolitana do Rio de Janeiro. Uma de suas frentes de trabalho é a abertura de editais de seleção para apoio e financiamento de projetos de impacto social, tal qual o projeto "Ressuscita São Gonçalo".

A proposta central do projeto "Ressuscita São Gonçalo" é pensar/fazer políticas públicas de forma horizontal, considerando os anseios da população. À vista disso, após vencerem o edital, através de redes de contato e canais de comunicação virtual, os jovens promoveram uma consulta pública, cuja pergunta norteadora foi "Qual cidade nós queremos?". Foi a partir das informações coletadas na consulta que os jovens pretenderam debater soluções e criar uma agenda inovadora que repercutisse em políticas positivas para São Gonçalo.

Tendo presente esta realidade, podemos nos perguntar: De onde vem a energia da liderança desses jovens? Quem ou o que são fatores que contribuem para

\footnotetext{
4 A Agenda Rio 2030 é um plano de ação global para a mudança do mundo 2030. São 17 Objetivos de Desenvolvimento Sustentável e 169 metas que orientam escolhas para a melhoria de vida dos países agora e no futuro. A agenda foi lançada como desafio global pela ONU em setembro de 2015. Disponível em http://www.agenda2030.com.br. Acessado em 21 nov 2019.

5 ONGs são grupos sociais organizados com fins públicos. Conforme a Lei 97.970/99, Art. 53 do Código Civil, constitui-se associações pela união de pessoas que se organizem para fins não econômicos. Destacamos que Fundações, Associações, Organizações podem ser consideradas ONGs, porém a verdadeira nomenclatura é OSCIPs (Organizações da Sociedade Civil de Interesse Público).
} 
a formação de seus engajamentos? Seria participação e engajamento político da juventude brasileira contemporânea um efeito inesperado das políticas de democratização e acesso ao ensino superior? Que espaços e situações de aprendizagem sensibilizam e (trans)formam as presenças subjetivas individuais em participação coletiva? De que maneira os saberes que possuem se articulam no contexto a seus ativismos?

Esses questionamentos deram suporte ao objetivo geral deste trabalho de identificar e compreender o (re)aprender dos jovens, os processos formativos que os constituem como atores sociais e suas motivações para o engajamento políticosocial em sua cidade. De forma específica, esta investigação procurou:

- Identificar saberes que estimulam as motivações dos jovens para o compromisso social em um mundo plural e complexo;

- Analisar os processos e experiências de aprendizagem que favorecem o engajamento social dos jovens;

- Valorizar os conhecimentos construídos nas ações/ lutas sociais;

- Analisar como se dá a relação entre as aspirações individuais desses atores e seu engajamento coletivo.

Buscou-se alcançar estes objetivos a partir de observações e entrevistas. As observações ocorreram em três atividades de interação entre os jovens do projeto "Ressuscita São Gonçalo" com a cidade. As entrevistas feitas de forma compreensiva ocorreram com 12 indivíduos, sendo 11 (onze) deles participantes das reuniões de tomada de decisões do referido projeto e um representante da ONG Casa Fluminense.

Esta investigação pretende responder as indagações propostas e compreender este movimento em uma perspectiva global, colocando a juventude e suas mobilizações no centro de nossa análise. Com o propósito de fortalecer a democracia global, articuladores e lideranças mundiais destacam a importância da participação da juventude na construção de novos caminhos para o planeta que tem enfrentado desgaste político, humanitário e geográfico.

Recentemente $^{6}$, a Organização das Nações Unidas (ONU), por meio de seu Secretário-Geral, Antônio Guterres reiterou o vigor da juventude que vem "exigindo corretamente um papel na formação do futuro", reafirmando que "o

6 Mensagem de boas-vindas ao ano novo de 2020. Disponível em: https://news.un.org/pt/story/2019/12/1699041. Acessado em 20 jan. 2020. 
mundo precisa dos jovens para continuar se manifestando, pensando alto, ultrapassando fronteiras e mantendo a pressão" para a realização de uma sociedade global justa, igualitária e sustentável. Em 2015, por exemplo, a Organização das Nações Unidas (ONU) aprovou a Agenda 2030 para o desenvolvimento sustentável ${ }^{7}$, cujo texto dirigiu especial atenção a "geração mais jovem de hoje, que vai passar a tocha para as gerações futuras".

No Brasil, eventos como as "Jornadas de Junho", em 2013, o "Movimento de Ocupação nas Escolas", , entre 2015 e 2016, e recentes pressões advindas das redes sociais virtuais com a etiqueta "\#adiaEnem"10, para adiamento do Exame Nacional do Ensino Médio (ENEM) de 2020, diante da emergência sanitária causada pela pandemia do novo coronavírus ${ }^{11}$, também são pontos referenciais para as reflexões sobre a importância da participação ético-política da juventude. A repercussão de tais movimentos, salienta que a juventude interpela a sociedade por melhores condições de vida e entra em cena buscando diálogo e interações que, fundamentalmente, promovem aprendizagens e leituras outras das realidades. Esses movimentos favorecem a promoção dos Direitos Humanos, especialmente no contexto histórico da modernidade ocidental, marcadamente excludente.

Os jovens percebem que mobilizar-se é algo que faz sentido, que influencia e que pode mesmo atemorizar as autoridades. E que, individual ou coletivamente, é possível interromper o fluxo do cotidiano e alterar o ritmo da vida nas cidades (CARRANO, 2015). Percebem, ainda, que participando de uma reflexão conjunta logram espaços de direitos e justiça social e, diante das impertinências da

\footnotetext{
7 A Agenda 2030 é um plano de ação com 17 objetivos e 169 metas para a transformação e desenvolvimento sustentável do planeta. Disponível em: https://nacoesunidas.org/pos2015/agenda2030/. Acessado em 18 jan. 2019.

8 "Jornadas de Junho" faz referência às manifestações ocorridas no Brasil em junho de 2013. Tais manifestações indicaram novos formatos de organização juvenil em crítica a partidos políticos e formas tradicionais de hierarquização do poder. Este ciclo de protestos, que engajou mais de 130 cidades em todo país, marca a história recente da temática entre juventude e participação política. Para mais informações o artigo PEREZ, Olívia Cristina. Relações entre coletivos com as Jornadas de Junho. Opin. Publica, Campinas, v. 25, n. 3, p. 577-596, Dec. 2019. Acessado em 29 jan. 2021.

9 O movimento de ocupação nas escolas entre os anos de 2015 e 2016 foi impulsionado pela insatisfação de estudantes do Ensino Médio. Dentre as insatisfações somava-se aspectos do cotidiano escolar e de políticas públicas educacionais. Estas ocupações são novas formas de ação coletiva das juventudes brasileiras. Para mais informações sugiro a tese de Tomaz, Adriana da Silva Lisboa; Bonamino, Alicia Maria Catalano de. Ocupação de três escolas estaduais no Rio de Janeiro: ação coletiva; reivindicações e conquistas. Rio de Janeiro, 2019. 190p. Tese de Doutorado - Departamento de Educação, Pontifícia Universidade Católica do Rio de Janeiro. Para uma visão panorâmica sobre as ocupações em território nacional sugiro reportagem do jornal O Globo/G1, 2019. Disponível em: http://g1.globo.com/sao-paulo/escolas-ocupadas/noticia/2015/12/ocupacoes-atos-e-polemicas-vejahistorico-da-reorganizacao-escolar.html. Acessado em: 20 fev. 2020 10 Nota da União Brasileira dos Estudantes Secundarista sobre os motivos para o movimento disponível em https://ubes.org.br/tag/motivos-para-adiarenem/. Acessado em $20 \mathrm{dez} 2020$.

11 No dia 11 de março de 2020 uma crise sanitária global foi anunciada como pandemia pela Organização Mundial de Saúde (OMS). Como forma de evitar o contágio além de constante higiene das mãos, recomendou-se fortemente distanciamento físico e forte apelo social para permanecer em casa.
} 
administração pública mobilizam, manifestam e protestam chamando a atenção para si, suas vozes e corpos.

Nesse sentido, reflexões a respeito da juventude, educação, cultura e participação ético-política no debate democrático constituem consistente campo de pesquisas e compreendem vasta discussão teórica, histórica e prática. Se conformam enquanto possibilidade de visibilizar uma juventude que cada vez mais busca reverberação entre as denúncias de incertezas que encontram no cotidiano e a inadequação deste cotidiano frente aos horizontes que pretendem ocupar. Como afirma Santos (2019, p. 148),

[...] o que desencadeia a resistência é uma descoberta tripla: a de que o opressor possui pontos fracos; a de que há caminhos, por estreitos que sejam, para lutar contra a opressão; e a de que há capacidade para percorrer esses caminhos.

\subsection{Composição da dissertação}

Esta dissertação é composta por 6 capítulos, organizados para gerar uma melhor compreensão dos principais temas que orientam esta pesquisa. Dessa maneira, após esta introdução, segue-se o capítulo intitulado "Juventudes, trajetórias e ativismo", que procurou abordar o tema da juventude e seu envolvimento sociopolítico na história recente. Os trabalhos de Dayrell (2003), Carrano (2006, 2009, 2012, 2015) e Leite (2017) colaboraram na configuração do que esta pesquisa entende por juventude - melhor dizendo, juventudes enquanto categoria social constituída no campo da pluralidade e diversidade de experiências. A partir das reflexões Leite e Araújo (2018), reconhecemos que o tema das juventudes e participação sociopolítica se (re)coloca emergente, especialmente com a adoção de novas formas de comunicação, como as redes sociais virtuais.

No capítulo "Decolonialidade, interculturalidade, processos educativos e ativismos juvenis", relaciono a emergência do tema das juventudes com a insurgência dos sujeitos em participação social. Procura-se evidenciar a necessidade de que "grupos sociais oprimidos representem o mundo como seu e nos seus próprios termos, pois apenas desse modo serão capazes de o transformar" (SANTOS, 2019, p. 17). Dialogo com trabalhos de Walsh (2009a, 2009b, 2012, 2016) e Candau (2008, 2014, 2016), para valorização das trajetórias “desde abajo”. 
A partir dos sentidos da interculturalidade crítica, considero o "comum" dos sujeitos em realidades subalternizadas pela modernidade/colonialidade e busco evidenciar a pedagogia e o pedagógico defendido pelas autoras. Dessa forma, reconheço juventudes em caminhos de luta e afirmação de vozes, corpos, inteligências e liberdades. Por este prisma, saberes e fazeres sociais devem ocorrer em intercâmbio com saberes e fazeres científicos, tendo como "premissa a ideia da inesgotável diversidade epistemológica do mundo" (SANTOS, 2007). Assim, novos engajamentos ajudam a impulsionar novas lógicas.

Em seguida, no capítulo "Fala e escuta das juventudes gonçalenses: metodologia da pesquisa", compartilho sobre o percurso desta investigação que ocorreu durante período da crise sanitária provocada pela pandemia do novo coronavírus. Justifico estratégias e descrevo os processos de levantamento do material empírico. Além disso, caracterizo os sujeitos participantes e a análise dos dados.

As experiências e realidades mapeadas no desenvolvimento desta investigação são elementos chave do trabalho e são apresentados no capítulo "Fala juventude: análise e discussão dos resultados". Nesta parte do trabalho apresento e discuto os resultados "conversando" com as informações e os relatos na ótica do referencial teórico mobilizado (KAUFMANN, 2013).

Nas considerações ao final deste texto coloco em perspectiva os caminhos pedagógicos encontrados "desde" e "com" os sujeitos participantes. Por fim, apresento ponderações e recomendações de futuras investigações com e a partir de práticas pedagógicas insurgentes.

Da mesma forma, espero, ao final deste trabalho, ter contribuído para a visibilização dos movimentos de jovens em lugares aparentemente abandonados pelas políticas oficiais, uma vez que as juventudes estão em movimento para a afirmação da justiça social. Reitero que os territórios periféricos se mostram organismos doutos em resistência e insurgência. Dessa forma novos trabalhos e olhares com e a partir destas regiões e seus sujeitos notabilizarão trajetórias outras de lideranças locais, reverberando processos formativos de efeito prático na vida dos indivíduos. 


\section{Juventudes, trajetórias e ativismo}

"É na rebeldia em face das injustiças que nos afirmaremos!"
Paulo Freire

Neste capítulo dialogo com reflexões e tendências teórico-conceituais que dão suporte a esta investigação. A intenção é aproximar e reconhecer entraves e potencialidades à participação social da juventude. A partir de autores e autoras, cujos trabalhos abordam a sua participação e engajamento político, faço um percurso que tenta capturar características e elementos do engajamento social da juventude contemporânea que, inclusive, podem contribuir para pensar novas estratégias de luta por vida digna no contexto atual. Não pretendo uma narrativa enciclopédica. Busca-se compreender as reflexões propostas nos trabalhos das últimas duas décadas sob eco das conceituações encontradas em artigos seminais que tratam do engajamento político da juventude em diferentes gerações. O que, acredito, possibilitará ilustrar vozes de reverberação entre denúncias de seus cotidianos e inadequação das realidades juvenis frente aos horizontes que pretendem ocupar. Outrossim, este trabalho buscará indagar e escutar dos jovens suas reflexões sobre vida e projetos de futuro. Nesta perspectiva, Carrano (2006) afirma:

Sobre as condições que possuem para exercer participação social básica, num quadro ampliado de direitos públicos relacionados com o acesso à educação, à cultura, ao lazer, ao trabalho e a tantos outros planos essenciais que podem fazer a vida digna (CARRANO, 2006, p.3).

\subsection{Jovens e envolvimento sociopolítico na história recente}

O tema das juventudes e participação sociopolítica (re)torna emergente. Parece contribuir com chaves de leitura na afirmação e promoção dos direitos humanos, especialmente no contexto histórico da modernidade ocidental, marcadamente excludente. Historicamente juventude e negociação sociopolítica estão conectadas. Especialmente quando reúnem suas insatisfações no propósito de 
fortalecer a democracia global e a construção de novos caminhos para o planeta que tem enfrentado desgaste político, humanitário e geográfico.

Reitera-se aqui, mais uma vez, as questões que provocam este trabalho: existiria, portanto, algo de particular na trajetória dos jovens que se envolvem em defesa de ideais democráticos? Em suas trajetórias, que circunstâncias pedagógicas são mobilizadas e/ou mobilizam seus ativismos? Quais variáveis, processos e dinâmicas motivam a posição assumida em seus envolvimentos? Contudo, antes de empreender sobre trajetórias de jovens ativistas enquanto objeto deste estudo, foi fundamental mobilizar referenciais que colaborassem para a compreensão histórica dos estudos sobre jovens, educação e participação social.

Deste modo, "Juventude e contemporaneidade", número especial da Revista Brasileira de Educação (RBE) organizado por Angelina Teixeira Peralva e Marilia Pontes Sposito (1997), constituiu-se em valioso material para o delineamento teórico sobre a maneira de se pensar juventude nesse trabalho. Os artigos presentes nesse número da RBE indicam percepções e representações não somente sobre os jovens em questão, mas sobre elos entre cidadania e política e os principais interesses que estão em jogo na sociedade, uma forma de pensar a juventude que muito contribui com o pensamento elaborado nessa dissertação. Recuperando, dessa forma, Melucci (1997) afirma que

a presença dessas diferentes experiências temporais não é novidade, mas certamente em uma sociedade ou mesmo na sociedade industrial do século XIX, existiu uma certa integração, uma certa proximidade entre experiências subjetivas e tempos sociais, e entre os vários níveis dos tempos sociais (MELUCCI, 1997, p 7).

No processo de luta social contra a ditadura no Brasil e à busca de um caminho de transição, a ideia da participação cidadã na sociedade civil adquire especial relevância, especialmente de grupos e movimentos organizados, na formulação, implementação e fiscalização de políticas públicas, especialmente na área social (SPOSITO, 2000).

Na década de 1960, aos moldes de uma "juventude rebelde" 12 , descrita por forte relação dos jovens e a política nas organizações estudantis, os chamados militantes estudantis atuavam sob "prisma de múltiplas dimensões e projetos emergentes dos jovens da classe média universitária radicalmente de oposição

12 Sobre essa questão ver: KADT, Emanuel de. Católicos radicais no Brasil. Brasília: Ministério da Educação, Secretaria de Educação Continuada Alfabetização e Diversidade, UNESCO, 2007. - (Coleção Educação para Todos; 17). 
política” (MISCHE, 1997, p 140). Apesar de todos os riscos, a luta contra interdições ao estado democrático e a liberdade de direitos é algo pelo qual valeu a pena se organizar. O movimento estudantil ganhou novas formas de reconhecimento pelo poder de confronto com o Estado militar (CARRANO, 2015).

Quanto a participação juvenil entre os anos 1980 e 1990, especialmente após o movimento dos "caras pintadas", as gerações apresentaram certos contrastes em suas formas de organização (MISCHE, 1997). Os espaços que compõem as trajetórias juvenis são considerados em suas formas menos centralizadas que na militância universitária. Escolas públicas e privadas, boates, bairros e ruas, shopping centers e locais de trabalho se tornam locais para engajamento e discursos mais abrangentes sobre os jovens e a cidadania.

Jovens com algum interesse político agora podem escolher entre muitas formas alternativas de militância, incluindo partidos políticos, movimentos populares, sindicais e antidiscriminatórios, organizações não governamentais e associações profissionais (MISCHE, 1997, p. 144).

À medida que os jovens alternam de círculos familiares para círculos de socialização mais complexos, a estrutura do mundo juvenil é reorganizada "tanto em interesses planetários, quanto em interesses na vida cotidiana” (MÜXEL, 1997, p. 163). O tema da juventude e seus interesses em práticas coletivas alcança notoriedade. Opinião pública e produção acadêmica tratam da temática. Produtos e programas de tv dão atenção especial aos diferentes estilos musicais que costumam agregar os jovens. Sobre a tematização da juventude, o trabalho de Abramo (1997) pondera sobre os interesses massivos da grande mídia em conformidade com o senso comum de "problemáticos" referidos aos jovens. De acordo com a autora, as cenas sociais compunham os jovens limitados a comportamento social destrutivo, "atuando num plano comportamental e cultural sempre vizinho aos planos do hedonismo, por um lado, e da violência, por outro" (ABRAMO, 1997, p. 35).

Por meio dos trabalhos e pesquisas acadêmicas, os jovens expressaram-se entre ter vontade de participar e reconhecer inércia, relatos de perda de confiança por promessas não cumpridas e/ou engajamento artesanal, "não se tratando de mudar o mundo, mas melhorar as coisas" (MÜXEL, 1997, p. 162). Análises de cenários em participação ora mais ou menos otimistas, ora mais ou menos pessimistas (MÜXEL, 1997). Ou, seriam, ainda, expectativas sociais com base na memória do movimento juvenil dos anos 1960 ? 
Tal qual a literatura parecia preocupar-se somente com a categoria jovem estudante em suas investigações (SPOSITO, 1997, 2017), recaia sobre quem não estava nas instituições de ensino, manifestando rebeldia ou conformidade com a situação social. Sem indagar ou abrir-se aos sentidos e condições de outros jovens e outras formas de saber e fazer participação política. Entre a ideia criada sobre participar e não participar é preciso admitir que os jovens têm formas próprias de identificação e organização social. Não se tratando, portanto, da dicotomia entre apatia e rebeldia. É necessário perceber as mobilizações como legado e alargamento das ações coletivas em processos históricos.

A multiplicidade de relações e significações sociais, e o caráter interativo e processual de toda experiência social. [...] tanto os mundos interativos dos jovens, quanto as relações emergentes entre os grupos organizados, e os pontos de convergência e distanciamento entre os dois (MISCHE, 1997, p. 135).

Em muitas investigações que majoritariamente vinculam jovens e escola, o tema dos grupos juvenis é emergente (CORTI; SPOSITO, 2002). Jovens como atores sociais "mesmo se apresentam diferenças históricas e geográficas com o passar das décadas, dividem características comuns que indicam padrão emergente de movimentos em sociedades complexas" (MELUCCI, 1997, p. 11). Os jovens seriam ao mesmo tempo protagonistas e destinatários de benefícios e prejuízos dos processos da modernidade/colonialidade.

Como um espiral de participação social contribuem para redefinição de sentidos e prática política, “embora se estruturem tendo referências e princípios comuns, esses grupos se diferenciam em relação a vários aspectos" (GUIMARÃES, 1997, p. 200). Não se tratando somente de uma juventude de ontem e uma juventude de hoje e amanhã. Firmada no passado heroico e fundador de formas e conteúdos de se fazer política, mas um tempo histórico em que seus atores se colocaram em cena tal qual os jovens de hoje e oxalá do futuro.

Na visão de Carrano (2012) há uma rua de mão dupla entre o que os jovens herdam e a capacidade de cada um construir seus próprios repertórios culturais. Cada qual tende a ressignificar seus modos e a herança organizacional de seus grupos de interesse. Implicações possivelmente conectadas em experiências pessoais e imediatas ao problema. Disposições em reparação à vista de insatisfações às desigualdades sociais conforme suas percepções. Elementos da vida prática como espaço e fundamentação para constituição e manifestação da cidadania. 
Com o advento das novas formas de comunicação e mídias sociais, novos desafios são incorporados ao debate. Trabalhos como os de Guimarães (1997) e Almeida e Tracy (2003) evidenciam diferentes modos de ser jovem e distintas estratégias de intervenção no social. Contribuem na compreensão das diferentes formas de organização das "galeras" jovens. Não se trata aqui, sob forma alguma, de hierarquizar, mas recuperar, mais uma vez, os diferentes quadros e traços político-culturais na formação de sentidos e significados das origens e trajetórias juvenis na "geografia da nigth" (ALMEIDA; TRACY, 2003, p. 29). Nota-se, por exemplo, influências culturais advindas do funk, mas também do religioso gospel, punk e hip hop (BOGHOSSIAN; MINAYO, 2009).

A "galera" funk, companheira das "galeras" do rap, e hip hop, é deslocada à margem. Na estrutura da criminalização do funk apresenta-se o racismo. O funk e sua "galera" acompanham tendências estadunidenses aliadas à cultura negra, os estilos são adicionados a cena musical visibilizando realidades nas periferias brasileiras. Estilos musicais estigmatizados e vinculados à violência são visibilizados pela literatura como uma, mas não a única, das formas de engajamento político e cultural de jovens em centros urbanos. Amostra das questionáveis razões à estigmatização do segmento juvenil e intensificação midiática. Afinal, a quem interessa ouvir e visibilizar estratégias de resistências das favelas e periferias? Interseção nas diferentes cenas juvenis, por que certos jovens são situados em fase de imaturidade ou rebeldia sem causa aparente e a outros facilmente associa-se enredos de drogas e violência?

O principal argumento dos trabalhos analisados é evidenciar as formas interativas entre subjetividade e sociabilidade na cena juvenil. Estilos e manifestações culturais como fenômenos musicais fortemente centrados em diversão e anúncio de resistência popular. Guimarães (1997) centra o olhar sob as "galeras" da periferia urbana e frequentadora dos tradicionais bailes das comunidades. Almeida e Tracy (2003) construíram suas análises a partir das “galeras" jovens da classe média, frequentadores de bailes e casas de show.

O diálogo com os autores aqui referenciados situa-se como constante exercício para escapar de situações comparativas e despertar à diversidade da história e dos sujeitos. Um convite à reflexão e aproximação de teorias e práticas sobre as sensações e possíveis inseguranças da vida presente e dos projetos de futuro dos jovens. Apesar de tendências de desconfiança das políticas 
tradicionalmente vigentes, os jovens reagem, à sua maneira, com seus grupos e redes. Em processos de construção e adequação de planos e projetos de vida em cenário sociocultural demarcado por momentos de incertezas, os jovens e suas trajetórias podem contribuir com novas chaves de leitura sobre a realidade social vivida.

\subsubsection{Juventudes}

O fenômeno aqui estudado são as trajetórias, processos e caminhos pedagógicos, fazeres e saberes de jovens ativistas. A pesquisa opta pelo uso do termo "Juventudes" por um alinhamento com o referencial teórico do campo que reconhece a juventude, seja teoricamente, seja empiricamente, como compostas por agregados sociais e características continuamente flutuantes (SPOSITO; CARRANO, 2003). Situadas por mudanças de época e seus paradigmas, com destaque a categoria como sujeito social, sobretudo por trajetórias em diversidades e especificidades construindo-se então em juventudes, no plural (CARRANO, 2006; DAYRELL, 2003).

Seja sob ângulos de consumo e produção de cultura, estilos e comportamentos, violência ou problemas sociais, as discussões sobre os jovens ganhou volume (ABRAMO, 1997). O debate é disputado em três tempos: jovens como atores políticos, como problema social e como cidadãos. O campo de estudos mais afim a esta pesquisa refere-se "à pluralidade de situações e trajetórias labirínticas que configuram um quadro múltiplo de modos de viver" (CARRANO, 2008, p. 195) e, portanto, juventudes. Não como somatória de categorias, mas como elas se entrecruzam evidenciando tensões e horizontalidades. O que sugere um esforço social para relacionar os retratos das realidades teoricamente e vice versa. Uma dinâmica que considero de corresponsabilidade para colaborar com argumentos que contrariem a noção de juventude em conceitos pré-definidos.

Nesse sentido, as experiências de vida somada à literatura acadêmica colaboram na decisão desta escrita pelo plural. O plural, ou melhor a pluralidade como enfrentamento às categorizações que tendem a excluir a diversidade que acompanha os sujeitos. Em um país geograficamente extenso e culturalmente abundante como o Brasil, a experiência juvenil cada vez mais se coloca de forma 
ampla. Ser jovem está contido em sair da infância e devir ao mundo adulto, ao mesmo tempo que contém outras experiências e processos.

São gestos, símbolos, formas lúdicas de sociabilidade, redes de relacionamento, canções e múltiplas formas de utilizar e representar o corpo aparentemente sem sentido para os "de fora", mas que dão liga da experiência comunitária de vivência da juventude neste nosso tempo histórico (CARRANO, 2008, p. 187).

Trata-se, pois, de elaborar e refletir, neste estudo, com e a partir dos/das jovens e das juventudes em diversidade de perspectivas e histórias de vida. Opção teóricometodológica implicada na ampliação das formas de refletir a complexidade da categoria. Chaves para compreender o/a jovem para além de expectativas ou antagonismos, mas ao contrário enxergá-los, ouvi-los e, principalmente, considerálos em suas articulações com o social. Carrano (2015) reforça esse ponto de vista:

É preciso também estar atento para como os próprios sujeitos que são considerados jovens representam, encaram e experimentam o tempo de juventude e as diferentes maneiras de se entrar na vida adulta que são variáveis segundo as origens sociais de cada um (CARRANO, 2015, p. 1).

Numa primeira mirada, pode parecer relativização demasiada. Mas vale ressaltar que a experiência docente com os jovens colaborou para a compreensão que cada qual está implicado em escolhas, incertezas, aspirações e frustações localizadas individualmente, mesmo que coletivas. Enfatizando a realidade de identidades juvenis múltiplas. Construídas no contexto das condições objetivas e subjetivas do sujeito, "que interpreta o mundo e dá-lhe sentido, assim como dá sentido à posição que ocupa nele, às suas relações com os outros, à sua própria história e à sua singularidade" (DAYRELL, 2003, p. 43).

Na experiência das juventudes nada é igual, mas único e ao mesmo tempo plural. Família, moradia, escola, gostos, personalidade, descobertas, grupos de afinidade, relacionamentos, trabalho e tudo mais o que se vive. A multiplicidade de experiências que se conectam entre si e para este trabalho são base para valorização da existência das juventudes.

viver a juventude não é preparar-se para o futuro, para um possível “vir-a-ser”, entre outras razões porque os horizontes do futuro estão fechados para eles. O tempo da juventude, para eles, localiza-se no aqui e agora, imersos que estão no presente. $\mathrm{E}$ um presente vivido no que ele pode oferecer de diversão, de prazer, de encontros e de trocas afetivas, mas também de angústias e incertezas diante da luta da sobrevivência, que se resolve a cada dia. (DAYRELL, 2003, p. 49). 
A esse respeito exigem estar diante de políticas públicas que assegurem direitos. Acesso à educação, cultura, segurança, lazer, autonomia, trabalho e emancipação. De maneira que os processos aos quais se envolvem em suas trajetórias repercutam na vida presente e futura de forma satisfatória. A dificuldade governamental em compreender a especificidade desta etapa da vida é tamanha que as juventudes são estereotipadas por incompletude e vulnerabilidade social. Quando na verdade têm a contribuir socialmente enquanto protagonistas de "biografias originais" (CARRANO, 2008, p. 205) nos diferentes desafios às maneiras de ser jovem: gênero, orientação sexual, raça, religião e classe, entre outras.

As dificuldades de afirmação não cessaram, no entanto há alguns avanços ou formas para avançar. Especialmente pelas mudanças políticas inauguradas com a eleição de Luiz Inácio Lula da Silva (2003-2010) que herda em seu governo as juventudes como um "risco social” (SPOSITO; CARRANO, 2003, p. 20).

As medidas e as expectativas dos projetos destinados às juventudes brasileiras eram expressos com base no Estatuto da Criança e do Adolescente (ECA - lei federal $n^{\circ} 8.069$ ), promulgado em 1990. O ECA quebrou paradigmas ao considerar crianças, adolescentes e jovens como sujeitos em desenvolvimento. Somente em 2005 cria-se o Plano Nacional da Juventude (PNJ) que reconhece a especificidade da juventude e amplia o marco etário de 15 a 18 anos para 15 a 29 anos. E após cinco anos foi feita a emenda constitucional 65/2010, que modifica o artigo 227. Conferindo que

É dever da família, da sociedade e do Estado assegurar à criança, ao adolescente e ao jovem, com absoluta prioridade, o direito à vida, à saúde, à alimentação, à educação, ao lazer, à profissionalização, à cultura, à dignidade, ao respeito, à liberdade e à convivência familiar e comunitária, além de colocá-los a salvo de toda forma de negligência, discriminação, exploração, violência, crueldade e opressão (BRASIL, 2010).

No referido artigo, fica estabelecido, inclusive, a criação do Estatuto da Juventude (2013), proposto para regular os direitos dos jovens brasileiros, abrangendo suas potencialidades de intervenção e participação política e cidadã. Sob a égide de assegurar o exercício dos direitos sociais e individuais, o Estatuto da Juventude é, portanto, a atual referência nacional na disposição sobre os direitos dos jovens. Com destaque ao Capítulo 1, Seção 1, o Artigo $2^{\circ}$ sobre direitos, a saber:

I - promoção da autonomia e emancipação dos jovens; II - valorização e promoção da participação social e política, de forma direta e por meio de suas representações; 
III - promoção da criatividade e da participação no desenvolvimento do País; IV reconhecimento do jovem como sujeito de direitos universais, geracionais e singulares; V - promoção do bem-estar, da experimentação e do desenvolvimento integral do jovem; VI - respeito à identidade e à diversidade individual e coletiva da juventude; VII - promoção da vida segura, da cultura da paz, da solidariedade e da não discriminação; e VIII - valorização do diálogo e convívio do jovem com as demais gerações (BRASIL, 2013).

Nesse sentido, potência para estratégias de inclusão e participação das juventudes na cena social e democrática. Paralelamente, considerar que tais atos alargam entendimentos e garantias para a vida juvenil conforme direitos afirmados em lei. Na compreensão de Cunha (2011), a medida em que participam da vida social democrática os jovens acessam informações e tendem a ocupar outros espaços. Dessa forma, as políticas são potência para as juventudes quando incentivam a participação, ao mesmo tempo que participar torna-se campo fértil de conhecimento das políticas que lhe são destinadas (CUNHA, 2011).

Além de promover condições de aprimoramento de representação e promoção da cidadania, outro ponto que deve ser evidenciado em relação a participação e engajamento dos jovens na vida política da sociedade é seu “ caráter pedagógico e de elogio ao processo participativo por si só e independente de sua real capacidade ou intenção de alterar processos decisórios” (CARRANO, 2012, p. 87).

Para melhor compreensão da importância das novas formas de intervenção dos cidadãos jovens na esfera pública, Carrano (2012) afirma que

[...] participação não é um conceito pacífico e nem sempre traz em si o princípio generoso de envolvimento de todos nos processos de decisão. O conceito de participação assumiu ao longo da história sentido democrático passando quase mesmo a ser sinônimo de democracia (CARRANO, 2012, p.87).

Pelo princípio elencado “os grupos são laboratórios de vida pública democrática, entretanto, suas práticas precisam ser experimentadas nos territórios de encontro entre os diferentes sujeitos [...]" (CARRANO, 2006, p. 4). Partir das narrativas das juventudes, foco desta investigação, para reconhecer conhecimentos que foram subalternizados pela colonialidade/modernidade. Conhecimentos que, fundamentalmente, promovem aprendizagens, dinâmica de sentidos e sentimentos. Dinâmicas que atravessam as trajetórias de vida, impulsionando a um novo ciclo de participação.

No que diz respeito às manifestações ocorridas na última década e que tomaram as ruas do país, pode-se dizer que outras novas formas de mobilização 
entram em cena. A juventude evidencia em protestos públicos a necessidade de buscar mudanças e fortalecer o debate democrático. Esta realidade salienta a participação social e política da juventude como instigante objeto de pesquisa, ressaltando mais uma vez a complexidade e profundidade de análises das juventudes na sociedade.

Jovens de todos os estratos sociais se envolveram em distintas formas de participação social, desde as mais tradicionais relacionadas a partidos e organizações estudantis, até novas formas de mobilização social relacionadas com ações voluntárias de solidariedade [...]. Jovens das periferias das cidades se articulam em torno de identidades móveis, ambíguas e flexíveis que emergiram e se desenvolveram em espaços periféricos da sociedade, numa resposta possível a crise estrutural do capitalismo que elevou enormemente o grau de incerteza no processo de trânsito da juventude para a vida adulta (CARRANO, 2009 p.190).

\subsubsection{Engajamentos juvenis e novas formas de participação}

A juventude vive tempos de mobilizações e encontros coletivos que passaram a confrontar o imaginário de uma juventude politicamente indiferente na história social contemporânea (CARRANO, 2015). Eventos como as "Jornadas de Junho" em 2013 e o "Movimento de Ocupação nas Escolas", entre 2015 e 2016, são atribuídos ao protagonismo juvenil contemporâneo. Os jovens estariam orientando suas manifestações para o "simbólico, para o corpóreo e o cultural diante de demandas do cotidiano" (CARRANO, 2012, p. 94).

Os acontecimentos durante e após os grandes protestos de junho de 2013 produziram um cenário fértil. Para efeitos de análise dos movimentos sociais e ações de participação coletiva "não há dúvidas de que as manifestações expressam contradições e tensões em estado de ebulição no contexto social brasileiro" (OLIVEIRA; LEÃO, 2019, p. 1014). São contextos de ações coletivas, com novos repertórios e linguagens. De alcance nacional, as manifestações ocorreram em várias regiões do país. Reinvindicações e negociações que conferiram relevância aos recentes episódios de mobilização popular na luta por garantia de direitos constituídos e qualidade nos serviços públicos essenciais como educação, saúde e transporte. O que pode ser considerado como demonstração do rearranjar da juventude que se dirige criticamente a precariedade da vida, emitindo "[...] sinais antagonistas aos sistemas que interditam a vida no presente, constrangem a 
participação na vida pública e fazem do futuro um campo de incerteza (CARRANO, 2015, p. 2).

Paradoxalmente, ao mesmo tempo que se nota "a capacidade de ação dos jovens, sua rebeldia e imaginação criativa, sua resistência aos processos que acentuam desigualdades de vários matizes, sejam sociais, de gênero ou étnicas e raciais" (SPOSITO; TARÁBOLA, 2017, p. 4), percebe-se também o surgimento de mobilizações de caráter divergente.

O trabalho de Sposito e Tarábola (2017), identificou, em levantamento de publicações na Revista Brasileira de Educação (RBE), que este "novo tipo de engajamento" apresenta demandas discrepantes. Além dos ativismos em Direitos Humanos, há também um tipo de engajamento com posições conservadoras e fundamentalmente centradas na lógica elitista, que caminham de mãos dadas com políticas neoliberais e promovem coletivos ainda pouco investigados. Ressalta-se a necessidade de atenção à existência de tais grupos também como movimentos de juventudes organizados, que, operando por ataques à democracia, aos direitos sociais e a liberdade de imprensa, valem-se da moral cristã para discursar “desconfiança em relação aos canais institucionais de participação, bem como desconfiança em relação a associações como partidos ou sindicatos e preferências por ações políticas pouco institucionalizadas" (CORROCHANO; DOWBOR; JARDIM, 2018, p. 51).

Existem diferentes perspectivas para a analisar os fenômenos relacionados às juventudes e participação social. Esta investigação se coloca na perspectiva de entender a participação social do conjunto de jovens em caminho de resistência e insurgência. A partir e com sujeitos que (re)agem de forma propositiva. Uma posição que não é ingênua e se coloca em atenção ao crescente contexto de negação de direitos fundamentais que pareciam já plenamente assegurados na mentalidade e nas políticas internacionais (CANDAU, 2008). Nesse sentido, "trata-se de afirmar uma perspectiva alternativa e contra hegemônica de construção social, política e educacional” (CANDAU, 2008, p.54).

"Diante dos inúmeros raios de luz que esse ponto inicial tem provocado" (SPOSITO; TARÁBOLA, 2017, p. 14), tais eventos apresentaram-se sob diferentes ângulos à sociedade, sendo possível considerar o ponto comum entre as "Jornadas de Junho" e o "Movimento de Ocupação das Escolas", promovendo variedade de reflexões sobre e a partir dos sujeitos jovens envolvidos. 
No que diz respeito às manifestações, as ruas e as escolas foram ocupadas por uma diversidade de sujeitos. Com predominância juvenil, inserem cultura própria e múltiplos processos de subjetivação. As juventudes, tem realçado a intrínseca relação entre participação social e política e educação-emancipação.

Muitos jovens quiseram marcar o direito à existência para revelar as cores agudas que constituem o cotidiano de sua vida escolar, sua experiência pessoal e singularidade. Os modos e a intensidade dos engajamentos revelam experiências dissimiles, unificadas nos momentos de visibilidade, mas presentes em sua diversidade no dia a dia da vida escolar (SPOSITO; TARÁBOLA, 2017, p. 17).

São diferentes formas de participação em contextos de luta e resistência. Tanto em contexto cotidiano, quanto na produção acadêmica estão presentes coletivos juvenis alinhados ao discurso democrático. As juventudes enfrentam, resistem e, igualmente, propõem pautas de inclusão e superação das desigualdades sociais. Protagonistas, individual e/ou coletivamente, constroem novas narrativas. Nesta perspectiva, Leite e Araújo (2018) discutem subversões de jovens à lógica educacional proposta a época das manifestações.

[...] foram apresentadas as pautas dos movimento, que giravam em torno de demandas por melhorias de infraestrutura das escolas, pela garantia do financiamento público por educação e por questões de ordem curricular e organizacional das escolas - sempre narradas em termos de defesa do direito de todas/os à educação democrática e de qualidade -, além de reinvindicações por melhores condições de trabalho para docentes e trabalhadoras/es terceirizadas/os. Foram ainda enfatizadas as lutas feministas, antirracistas e pelos direitos das populações LGBT, não apenas na sociedade em geral, como também no dia a dia da educação escolar e na própria prática das ocupações (LEITE; ARAÚJO, 2018, p.101).

\subsection{Ativismos juvenis}

Os jovens percebem que individualmente ou em coletivos podem alterar ritmos cotidianos e processos socialmente impostos. Apoiados em seus próprios contextos e motivações de vida, mobilizar-se é algo que faz sentido, que influencia e que pode mesmo provocar autoridades a repensar políticas públicas (CARRANO, 2015). Razão pela qual Leite (2017) aponta o ativismo político das juventudes contemporâneas como representações que crescem e multiplicam-se no país. Para a autora, os movimentos de ocupação urbana dos últimos anos podem ser considerados como novos horizontes na ordem social e "trazem aspectos das 
relações entre juventude e cidade que vão além da presença física do ativismo político" (LEITE, 2017, p. 179).

Em relação a esta questão, Gonh (2018), afirma que as refutações dos jovens à atual "velha política" ressignifica a relação entre ser militante e ser ativista. De igual modo, práticas, valores e "as emoções dos indivíduos e dos coletivos ganham destaque nos protestos políticos e podem assumir papel ativo da construção do social" (idem, p. 125). O movimento foi tanto interpartidário, como em alguns momentos, antipartidário. Colaborando com o (re) surgimento de eventos como pontos referenciais de um novo ciclo de "ação desses jovens na sociedade e nas políticas públicas, destacando a cultura política criada (ou ressignificada) e a renovação operada na questão da participação dos jovens a partir do uso das redes midiáticas" (idem, p.125).

Em uma investigação com jovens do Movimento Tarifa Zero em Belo Horizonte/MG, Oliveira e Leão (2019) captam distinções entre as gerações ativistas atuais e as gerações militantes das décadas anteriores. Os autores consideram que ao contrário da utopia que mobilizou os jovens militantes à época da redemocratização do Brasil, hoje os jovens ativistas vivenciam ações imediatas com seus cotidianos. De acordo com Oliveira e Leão (2019) são pontos chamativos para as novas formas de ativismo o trabalho de base nos bairros, locais de trabalho, escolas e comunidades. As críticas trazidas pelos jovens ativistas "indicavam o desenvolvimento de um engajamento que podemos definir como vigilante sobre a cidade e sobre o poder municipal. [...] além da necessidade de uma outra vida na urbe calcada no direito social ao acesso a espaços e a equipamento na cidade (OLIVEIRA; LEÃO, 2019, p. 1023).

Tais considerações podem derivar em outras investigações das relações de conhecimentos e conflitos geracionais entre militantes e ativistas contemporâneos. Ou ainda, contribuir para a proposição tão cara a este trabalho: evidenciar saberesfazeres presentes nas trajetórias dos jovens ativistas contemporâneos. Sobretudo ao considerar a posição de experiências, aprendizagens e educação, este trabalho busca evidenciar e expressar nuances em "que a leitura do mundo precede a leitura da palavra e a leitura desta implica a continuidade da leitura daquela" (FREIRE, 1989, p. 13). Postula-se a relevância dos processos em que "vamos nos fazendo aos poucos, na prática social de que tornamos parte” (FREIRE, 2001, p. 40). Por sua vez, que toda inserção política se configura como importante espaço de formação 
dos sujeitos frente aos caminhos de luta. Onde os momentos vividos em várias épocas servem-nos para percepções e leituras do tempo atual.

Dessa forma, a ressignificação de movimentos e atores sociais ganha força e assume cada vez mais espaço. São novas formas de comunicar inquietações, sobretudo quando reúnem insatisfações frente ao social que se impõe. O tempo atual é referenciado por eventos e mobilizações como um "mar de gente" em ocupação das ruas e o "tsunami" das novas mídias. A mediação das tecnologias, sejam antes, durante e depois dos atos, seja para convocação, para registro e compartilhamento da experiência, com o engajamento virtual foram ativadas. Nas palavras de Costa (2016)

vivemos um momento de total imersão tecnológica e, consequentemente, de transformação das práticas em diversos setores da sociedade. [...] Ou seja, estamos imersos na tecnologia praticamente 24 horas por dia e isso inaugura uma nova forma de pensar o mundo e se colocar no mundo (Costa, 2016, np).

As redes sociais de internet favorecem manifestações de criatividade para novas formas de comunicação, identificação e organização de participação social e política. De acordo com Carrano (2015), ao extrapolar fronteiras geográficas, surgem diferentes formas de coletivizar inquietações.

As redes sociais de internet são dispositivos que possibilitam instantaneidade da resposta por agentes individualizados ou coletivos que possuem grande agilidade para produzir conteúdos mobilizadores [...]. Através de publicações rápidas, comentários e mesmo o simples "like" do facebook, se constroem cumplicidade entre diferentes atores envolvidos nos protestos e mobilizações (CARRANO, 2015, p.3).

Ao amplificar reinvindicações, as redes sociais virtuais contribuem para o reposicionamento de vozes que subvertem adultocentrismos que marcam grande parte das organizações sociais (LEITE, 2017). Interações no interior dos grupos favorecem diálogos e a criação de símbolos que aproximam sujeitos jovens que estão distantes geograficamente, mas que se interconectam na rede como um dispositivo político (COUTO JUNIOR et al., 2019).

Os/as jovens trocam experiências de resistências e identificam-se interconectados pela cotidianidade. Visibilizam, como na investigação de Couto Júnior et al (2019), as constantes imposições sobre corpo, gênero e sexualidade que “[...] potencializam a condição de precariedade das vidas em vulnerabilidade [...] e, no caso específico das normas de gênero, subalternizam e marginalizam aquelas/es 
que não se enquadram no binarismo masculino/feminino e que não se identificam com a heterossexualidade" (COUTO JUNIOR et al., 2019, p. 1212).

Ações online de alertas e denúncias em tempos de violência ao diverso. Laços e interações não somente de autodefesa, mas de resistência e responsabilidade social. Entre construção e troca de conhecimentos e culturas, a coletivização de argumentos que impulsionaram

"as/os participantes do estudo a se engajarem na tarefa de juntas/os, mobilizarem-se eticamente em torno de ações ciberativistas que buscam garantir estratégias de (re)existência em prol de reconhecimento e da legitimidade de vidas que historicamente, vem sendo silenciadas e apreendidas em condição de precarização (COUTO JUNIOR et al., 2019, p. 1220).

A pluralidade de atores traz consigo a diversidade de pautas. Diálogos para o bem estar social entre a ideia de coletivo e particular vividos na precariedade de Estados e municípios do Brasil. A insurgência dos movimentos de ocupação dos espaços da cidade entre escolas e praças são como caminho de apropriação das discussões do campo democrático. Criticam o sistema escolar "que tende a priorizar o individualismo e não parece investir na construção do pertencimento e da responsabilidade social" (LEITE; ARAÚJO, 2018, p.101). Com relação ao movimento de ocupação das escolas, a pesquisa realizada com “jovens mais jovens" com idade entre 13 e 18 anos, chama a tenção para a opção em ocupar e não abandonar. As juventudes contestam a ordem dominante e, conforme afirmam as autoras, apresentam-se como

uma juventude comprometida com o coletivo e o político, em arrojadas bases igualitaristas, que buscam equacionar igualdade e diferença, o que entendemos nos autorizar a rejeitar o rótulo de presentista para esse agrupamento social. (LEITE e ARAÚJO, 2018, p, 103).

Entre repressão policial e ações de depredação por parte de alguns grupos, os eventos assumiram um caráter festivo. Ideais sociais não apenas mobilizados, mas que mobilizam. Do ponto de vista de Carrano (2015) "as manifestações foram produtoras de empoderamento pessoais significativos [...] A realidade parece dizer "meu corpo tem poder", "minha voz pode ser ouvida" e "eu posso influenciar" na construção de mudanças" (CARRANO, 2015, p. 3).

Entre os sentidos conferidos a participação política, Sposito e Tarábola (2016) ilustram narrativas de estudantes universitários de camadas médias e populares de diferentes instituições públicas de São Paulo. Autor e autora, 
recuperam reflexões e análises sobre as diferentes gerações e seus engajamentos que exige diálogo com contextos e tensões presentes na esfera pública.

Estaríamos diante de um desafio histórico e estrutural marcado pela pluralidade de modos de vida e da diversidade de situações que singularizam as trajetórias individuais nos coletivos no interior de um miríade de conflitos sociais ao lado de certas reiterações que continuam tratando da questão de modo hegemônico, como se política e o engajamento fossem expressões autoevidentes dotadas de significado único por meio de quadros de referência ou de narrativas que já não dão conta dos novos processos históricos que emergem mesmo de maneira não visível (SPOSITO; TARÁBOLA, 2016, p. 1013).

Sposito e Tarábola (2016), organizam tipos de participação e engajamento que não se excluem entre si, mas apresentam-se para considerar a implicação afetiva do agir político. Neste caso, anterior ao ingresso no Ensino Superior o engajamento de "rapazes e moças que participam da criação de coletivos nos bairros populares, seus locais de moradia (idem, p. 108). No meio universitário "a entrada em coletivos favorece a afirmação dessas identidades que rompem com modelos normativos dominantes" (idem, p. 1019). Posterior ao ingresso no Ensino Superior as associações estariam então vinculadas ao movimento autônomo "de doação, recebimento e devolução" (idem, p. 1021) já que venceram as dificuldades de acesso à universidade.

Para Sposito e Tarábola (2016), militantes a moda "tradicional" e as novas formas de engajamento com adesões mais provisórias propiciam reflexões sempre em construção e desconstrução. Os autores aprofundam situações do cotidiano nas trajetórias juvenis, modos de compreender os jovens e as tensões intrínsecas à juventude no que diz respeito a diversificação de papéis que desempenham socialmente. Desaprender, para aprender com os/as jovens que são filhos e filhas, estudantes, netos e netas, são trabalhadores, alguns já em experiência de paternidade e maternidade (ou ambos). Todos/as os/as jovens são produtores de cultura e possuem identidades específicas.

Jovens cujo potencial criativo em seus posicionamentos e biografias têm a capacidade de alargar a compreensão sobre processos de autonomia e consciência, individual e coletiva. Como "uma rua de mão dupla entre aquilo que os jovens herdam e a capacidade de cada um construir seus próprios repertórios culturais" (CARRANO, 2012, p. 86). Representações que despertam ressignificações na construção das identidades dos/as jovens. 
Dentre a variedade de papeis que desempenham, para muitos jovens está colocada a necessidade de inserção no mundo de trabalho. Um "mundo heterogêneo e fragmentado, distante do universo da fábrica, mas também marcado pelas formas em que as desigualdades se processam na sociedade" (SPOSITO, 2014, p. 104). Conforme aponta o trabalho de Carrano (2012), sobre a participação social e política de jovens no Brasil, “a busca pela sobrevivência não é compatível com o tempo livre (idem, p.95).

É relevante ressaltar que em investigação realizada com jovens que estudam e trabalham identificou-se as dificuldades em permanecer na escola. "As trajetórias escolares de boa parte dos jovens da pesquisa apresentaram percursos intermitentes de idas e vindas à escola em diferentes momentos da vida" (CARRANO; MARINHO; DE OLIVEIRA, 2015, 1449). Seja em situação de permanência no Ensino Fundamental e Médio ou ingresso no Ensino Superior a vida se coloca em urgências sob condições objetivas quase que pressionando decisões entre isso ou aquilo. Se há uma noção de futuro atribuída aos jovens, de que formas essas perspectivas saem do plano do desejo? Há espaço para escolhas?

Carrano, Marinho e De Oliveira (2015) ouviram dos/das jovens entrevistados/as que estudar e trabalhar não é de todo negativo. Configurando-se como "campo de possibilidades para ampliação de horizontes de futuro, o que pode ter contribuído para renovar os sentidos da presença na escola" (idem, p, 1451). Elementos relevantes para se pensar com as juventudes e espaços que transitam. Espaços que cada vez mais disputam entendimentos sobre o físico e o virtualizado. Com a projeção das novas tecnologias, as redes sociais virtuais comunicam desejos, anseios e posicionamentos políticos. Entusiasta das redes sociais de internet, os jovens atuam com propriedade para aligeirar a comunicação, organização e divulgação de pautas e demandas que consideram significantes (GOHN, 2018). Dimensões cada vez mais amplas do anuncio feito por Castells e Carsoso (2005) sobre uma nova estrutura social na dinâmica contemporânea, a sociedade em rede.

A sociedade em rede também se manifesta na transformação da sociabilidade. O que nós observamos, não é o desaparecimento da interação face a face ou ao acréscimo do isolamento das pessoas em frente dos seus computadores. Sabemos, pelos estudos em diferentes sociedades, que a maior parte das vezes os utilizadores de Internet são mais sociáveis, têm mais amigos e contatos e são social e politicamente mais ativos do que os não utilizadores. Além disso, quanto mais usam a Internet, mais se envolvem, simultaneamente, em interações, face a face, em todos os domínios das suas vidas.(CASTELLS; CARSOSO, 2005, p, 23). 
Transformações dinamicamente velozes e múltiplas. O trabalho de Feixa e Weissböck (2019) dá pistas para pensar o tempo social e tecnológico no qual este trabalho está situado. O marco das mudanças não são guerras ou revoltas, mas a revolução digital com novas formas de protestos e, eventualmente, atores de diferentes países convocando-se uns aos outros. Conferindo complexidade entre ascensões e exclusões digitais amplamente referenciadas em estudos da cultura juvenil e cultura digital.

As redes sociais abrem novas possibilidades entre ver e ser visto. São trocas de informação, práticas de diálogos com capacidade de fortalecer grupos, agregar simpatizantes e opositores como já mencionado. Afirma-se que "são também contextos onde o coletivo cultiva laços de solidariedade, cooperação e coesão que favorecem a participação e a ação coletiva" (GARCIA; MACEDO; QUEIRÓS, 2019).

Os/as jovens e suas formas de ação estão imbricados/as nas transformações midiáticas. Em breves palavras, as/os sujeitos jovens à época dos anos 2000 ou “geração@” localizam o contexto de navegação, rede e comunidades virtuais. Nos anos seguintes, àquela geração @ de adolescentes experimenta nova fase da juventude. A "geração \#” é uma medida numérica para aglutinar ideias, repercutindo indignações e cenas locais com globais, alimentando os trending topics. Os que viveram a infância nos anos 2000 vão experimentar a juventude em 2020 com interconexões de dados, fake news e o tempo viral da "geração blockchain".

Para Feixa e Weissböck (2019), em “o efêmero jogo de papeis”, físicos ou virtuais, os jovens criam conteúdos e demandas de interatividade. Transgridem lógicas de espaço local versus espaço global, tempo real versus tempo virtual, sedentarismo versus nomadismo, tribo versus rede. As juventudes transitam entre utilização e consumo das redes sociais virtuais. De maneira que a noção de "geração @)" está em processo para a "geração \#” que se lança para o que de chama de "geração blockchain". A novidade, portanto, está na amplitude do engajamento tecnológico cujas “ características do digitalismo se intensificam e se expandem por diversos nichos sociais e geográficos"(FEIXA; WEISSBÖCK, 2019, p. 17). É possível que outras investigações sobre a temática estejam em curso com vias de compreender "outra parte do tempo social" sustentada massivamente de trocas virtuais. Especialmente em situação pandêmica provocada pelo novo coronavírus 
que impôs o distanciamento físico e maior fluxo de comunicação em ambientes virtuais.

A partir da abordagem mobilizada neste trabalho para compreender as juventudes é possível afirmar que as gerações não são estruturas compactas, mas posições de referenciação simbólica dos sujeitos socializados. Cabendo à investigação e seu tempo social o exercício de pensar com e a partir as juventudes globais e locais, nos espaços que elas transitam. Dessa maneira, com resistência e luta surgem novas avaliações de condições e experiências concretas que ressignificam subjetividades individuais e coletivas (SANTOS, 2019, p. 53).

Reflexões a partir da organização, atuação e experiências que projetam possibilidades de compreensão das identidades juvenis na história recente brasileira, as juventudes e suas formas de participação política. Procurei, mesmo que brevemente, problematizar tensões, limites e potencialidades. Jovens em percursos a partir da complexidade social trilhando saídas às vias travadas na precariedade condicionada ao subalternizado: atores de diferentes contornos culturais presentes no espaço físico e virtual, mobilizando narrativas que problematizam desigualdades vividas no contexto atual. 


\section{Decolonialidade, Interculturalidade, processos educativos e ativismos juvenis}

"as brechas se transformaram no lugar e no espaço a partir do qual a ação, militância, resistência, insurgência e transgressão são impulsionadas, onde as alianças se constroem, e surge um modo-outro que se inventa, cria e constrói” (WALSH, 2016, p.

72).

Neste capítulo pretende-se relacionar a emergência do tema central da dissertação situando a pesquisa na valorização de epistemes invisibilizadas e subalternizadas. Múltiplos laços e caminhos pedagógicos cujas interfaces objetivas e subjetivas da vida favorecem e/ou dificultam inserção e participação social. Dito de outra forma, este capítulo pretende refletir o vívido que mobiliza a atitude responsiva com o social democrático.

Chama atenção a emergência de movimentos que problematizam áreas da vida cotidiana. Se por um lado a vida parece ser desenhada com "canetadas" que aprofundam desigualdades sociais, por lados "outros"13 há jovens engajados/as que questionam exclusões e enfrentam descasos que acompanham o binômio modernidade/colonialidade. Práticas de contestação política que tendem a inovar em seus formatos organizacionais de ativismos e representações (LEITE; FERREIRA; MACHADO, 2019).

Neste contexto, o debate sobre lutas, resistências e insurgências de jovens lideranças têm se tornado cada vez mais profícuo. Novas dinâmicas e mobilizações sociais contemporâneas, sobretudo das jovens lideranças de origem e atuação nas periferias urbanas, têm gerado formas outras de produção do conhecimento. Com suas próprias cores, identidades e localizações em tempo e espaço "glocal" os/as jovens questionam cotidianos marcados pela negação de direitos constituídos (FEIXA; WEISSBÖCK, 2019). Juventudes em caminhos de luta e afirmação de vozes, corpos, inteligências e liberdades.

Outrossim, articula-se neste trabalho a realidade da educação enquanto ato político, na perspectiva do que aponta Freire (2001) na realidade de "um ato de conhecimento, um ato político, um compromisso ético e uma experiência estética"

\footnotetext{
${ }^{13} \mathrm{O}$ grupo "Modernidade/Colonialidade" recorre ao uso do "outro" na intenção de não enaltecer um conhecimento ou perspectiva, mas sim uma mudança de lógica.
} 
(p. 55). Contextualiza-se, portanto, concepções teóricas com e a partir de elementos culturais, valores éticos e estéticos dos saberes/fazeres que perpassam a integralidade dos sujeitos sociais. Dessa forma, as reflexões que são propostas neste capítulo estão ancoradas na perspectiva da Interculturalidade Crítica e das Epistemologias do Sul cujo escopo político, pedagógico e epistêmico empenha-se em afirmar modos de ser, saber e viver historicamente subalternizados. Procura evidenciar que "grupos sociais oprimidos representam o mundo como seu e nos seus próprios termos, pois apenas desse modo serão capazes de o transformar" (SANTOS, 2019, p. 17).

\title{
3.1 Educação, resistências e mobilizações
}

O campo da educação, historicamente, é marcado por situações de disputa de narrativas. Disputas que são marcadas pela modernidade/colonialidade, que se apresenta como versão única da história. Reputado como natural e racional, o modelo de origem europeia de produção do conhecimento foi apresentado como fundamental nos processos educativos, visando "civilizar" os povos considerados subdesenvolvidos. A pretensiosa crença dos benefícios da homogeneização linguística e assimilação cultural acomodou-se por um tempo na ideia de liberdade e igualdade salvacionista da modernidade. No entanto, tal processo negou sistematicamente diferenças étnicas e culturais transformando-se em estrutura de desigualdades sociais, marginalização e exclusão.

Um dos eixos fundamentais desse padrão de poder excludente é a classificação social da população mundial sobre a ideia de raça, uma construção mental que expressa a dominação colonial do poder (QUIJANO, 2005).

\begin{abstract}
A formação de relações sociais fundadas nessa ideia, produziu na América identidades sociais historicamente novas: índios, negros e mestiços, e redefiniu outras. Assim, termos com espanhol e português, e mais tarde europeu, que até então indicavam apenas procedência geográfica ou país de origem, desde então adquiriram também, em relação às novas identidades, uma conotação racial. E na medida em que as relações sociais que se estavam configurando eram relações de dominação, tais identidades foram associadas às hierarquias, lugares e papéis sociais correspondentes, como constitutivas delas, e, consequentemente, ao padrão de dominação que se impunha (QUIJANO, 2005, p. 117).
\end{abstract}

Com a predominância de uma práxis colonial, a história e a cultura brasileiras não são contadas pelos nativos ou negros escravizados, mas através de uma única 
cosmovisão, pautada e justificada a partir da herança euro/usacêntrica ${ }^{14}$. Chegando a criminalizar $^{15}$ o que é do outro, do não-branco, impregnando a ideia de classificação entre bom e mau, aceito e não aceito, e, por conseguinte, a construção do conceito de raça e as manifestações do racismo.

Do modo como foi constituída a modernidade europeia, a hegemonia epistêmica, política e historiográfica ainda está presente nas relações cotidianas. O discurso de dominação e diferenciação foi ampliado sob a invenção do saber legítimo, único/científico, em negação aos saberes diversos e originários presentes nas identidades indígenas e afrodiaspóricas.

O padrão de poder baseado na colonialidade implicava também um padrão cognitivo, uma nova perspectiva de conhecimento dentro da qual o não-europeu era o passado e desse modo inferior, sempre primitivo (QUIJANO, 2005, p. 127).

O colonialismo cerceou indivíduos em sua liberdade e identidade. Ao rejeitar a racionalidade e história não europeias, classificando como maléficas suas manifestações culturais, tornou invisível o que é outro, julgando como subhumanidades manifestações epistêmicas e culturais dos povos não-europeus.

Com base no que Quijano (2005) identifica como matriz colonial de poder, Mignolo (2017), qualifica como "o lado mais escuro da modernidade" a colonialidade. Para o autor, o fundamento histórico da matriz colonial de poder é construída e opera como amarras histórico-estruturais heterogêneas e interconectadas, que são atravessadas por diferenças coloniais e pela lógica subjacente que assegura essas conexões até os dias de hoje.

À vista disso, contrapondo à lógica hegemônica, o grupo Modernidade/Colonialidade (M/C), denuncia a colonialidade enquanto condição promotora da modernidade europeia e do atual padrão de poder exercido por ela, que de acordo com Quijano (2002), vigora

[...] na articulação entre: 1) a colonialidade do poder, isto é, a ideia de "raça" como fundamento do padrão universal de classificação social básica e de dominação social; 2) o capitalismo, como padrão universal de exploração social; 3) o Estado como

\footnotetext{
${ }^{14}$ Uma ampliação da expressão "eurocentrismo", reconhecendo que os Estados Unidos ocupam um papel central na ciência e seu conhecimento, assim como a Europa, estão vinculados a ideia de progresso.

${ }^{15}$ Por exemplo, o Código Penal Brasileiro de 11 de outubro de 1890, pelo decreto número 847, Capítulo XIII com a Lei de Proibição da Capoeira. Lei revogada somente em 1937, que previa pena de prisão de dois a seis meses aos praticantes da luta de influência africana e indígena.
} 
forma central universal de controle da autoridade coletiva e o moderno Estado-nação como sua variante hegemônica; 4) o eurocentrismo como forma hegemônica de controle da subjetividade/ intersubjetividade, em particular no modo de produzir conhecimento (QUIJANO, 2002, p.4).

Como "quatro cabeças de um monstro", o controle da economia, da autoridade, do gênero e sexualidade, e do conhecimento e subjetividade relacionam-se e têm por "pernas" e sustentação a questão racial e patriarcal do conhecimento. Na percepção de Mignolo (2017), "assim foi configurada a enunciação da epistemologia ocidental, e assim era a estrutura da enunciação que sustentava a matriz colonial" (p. 6). Exclusões que repercutem nas relações em sociedade, especialmente na experiência latino-americana que, apesar dos contextos de independência política de seus países, vivem imersos nos efeitos de sua colonização, isto é, na lógica da colonialidade.

Como superar esta realidade que estruturalmente atravessa modos de conhecer e viver no mundo? A considerar a complexidade de "um monstro com quatro cabeças", não há resposta simples, tão pouco imediatas. Sobre isso, a rede multidisciplinar e multigeracional de intelectuais, o grupo Modernidade/Colonialidade, compartilha experiências, raciocínios e conceitos para reescrever a história global diante da necessidade de incorporar visões, personagens e relatos que levem em conta a história e cultura de povos invisibilizados (BALLESTRIN, 2013).

Ao "desocultar" forças que ignoram e excluem a diversidade de saberes, o grupo Modernidade/Colonialidade anuncia caminhos para afirmação de narrativas outras, em processos de reconhecimento, autoestima e empoderamento social enquanto agentes transformadores para (re) pensar a sociedade e o político-social.

Con esta perspectiva, no partimos del problema de la diversidad o diferencia en sí, ni tampoco de la tolerancia o inclusión culturalista (neo)liberal. Más bien, el punto medular es el problema estructural-colonial-racial y su ligazón al capitalismo del mercado. Como processo y proyecto, la interculturalidad crítica, como dicen los epítetos al inicio, "cuestiona, profundamente la lógica irracional instrumental del capitalismo" y apunta hacia la construcción de "sociedades diferentes [...], a otro ordenamiento social" (WALSH, 2012, p. 65).

Em oposição ao universalismo, sexismo e racismo, o ponto de partida está em entrelaçar teorias e práticas que envolvam indivíduos e movimentos sociais de resistências e proposições para ultrapassagem da colonialidade monocultural, 
epistemológica e pedagógica. Uma proposta de educação, resistência e mobilização a partir das vítimas,

[...] a partir das ruínas, das experiências e das margens criadas pela colonialidade do poder na estruturação do mundo moderno/colonial, como forma não de restituir conhecimento, mas de reconhecer conhecimentos "outros" em um horizonte epistemológico transmoderno, ou seja, construído a partir de formas de ser, pensar e conhecer diferentes da modernidade europeia, porém em diálogo com esta (OLIVEIRA; CANDAU, 2010, p. 23).

Apostando em trajetórias e caminhos pedagógicos acionados pelo vívido não mais subordinados a ideia de conhecimento único, mas constitutivo de saberes e fazeres. Um ponto de vista centralizado na radicalidade de "giro decolonial" 16 , pois com resistência e luta surgem novas avaliações de condições e experiências concretas que ressignificam subjetividades individuais e coletivas. Invocando necessariamente conhecimentos outros e igualmente válidos para a luta e resistência político-social (SANTOS, 2019, p. 53).

Nesse sentido, o distanciamento do pensamento ocidental precisa ser assumido perante o fato de que existem problemas modernos para os quais não existem soluções modernas, no entanto, sem desconsiderar as ricas contribuições do pensamento ocidental. Essa distância nos leva à aproximação dos conhecimentos subalternos silenciados pela modernidade (RIBEIRO, 2018, p. 1064).

Chaves analíticas que potencializam a compreensão de aprendizagens e conhecimentos com e a partir de engajamentos político-sociais contra hegemônicos. Ao mesmo tempo que é utopicamente provocativa "essa marginalidade teórica dialoga com as versões periféricas e subalternas produzidas fora do Norte" (BALLESTRIN, 2013, p.109).

Conhecimentos permeados por saberes construídos na esfera da vida. Saberes diversos, muitos deles, deslocados do escolar e do formal. Portanto, educação e pedagogias face a processos e estratégias de vida e luta, na luta por sobrevivência. Saberes/fazeres de construção e caminhos outros. Narrativas que atravessam e são atravessadas por conhecimentos que "se entrelaçam com a militância intelectual e o ativismo, formando um todo inseparável” (WALSH, 2016, p. 66).

No caso desta pesquisa, narrativas das juventudes de origem e atuação ativista em periferias urbanas. Assumindo o lugar do vivido e experimentado pelos sujeitos

16 Giro Decolonial é um termo que argumenta e denuncia colonialidade às realidades ética, política e epistêmica dos povos inferiorizados pela modernidade ocidental. Originalmente cunhado por Nelson Maldonado-Torres (2006), o termo giro decolonial manifesta resistência à lógica hegemonia. De acordo com Ballestrin (2013) o giro decolonial é um dos elementos da decolonialidade que faz com que os conhecimentos subalternizados notabilizem lugares epistêmicos do pensamento outro. 
jovens. Processos formativos proporcionados em experiências no "mundo heterogêneo e fragmentado, distante do universo da fábrica, mas também marcado pelas formas em que as desigualdades se processam na sociedade" (SPOSITO, 2014).

\subsection{Processos formativos e interculturalidade}

A questão central num projeto de emancipação epistêmica é a coexistência de diferentes conhecimentos. Dessa forma, a teoria e a prática aqui propostas, além de questionar a centralidade do pensamento hegemônico, assume o desafio de afirmar a partir de sujeitos e lugares outros, elementos, conhecimentos e concepções de mundo também outros. Argumentações interessadas em "outras formas de pensar e se posicionar a partir da diferença colonial, na perspectiva de um mundo mais justo" (OLIVEIRA; CANDAU, 2010, p. 27).

Assim, buscou-se trabalhos e reflexões que contribuíssem na empreitada de visibilizar o decolonial pedagogicamente e o pedagógico decolonialmente com o objetivo de colocar a pessoa no centro do conhecimento e a natureza no centro da pessoa. Fleuri (2003) afirma que "trata-se, na realidade, de um novo ponto de vista baseado no respeito à diferença, que se concretiza no reconhecimento da paridade de direitos" (p. 17). Um posicionamento que coloca força nas histórias locais, de memórias coletivas de resistência e existência. Uma vez que

somente considerando as formas de conhecer subalternizadas podemos ampliar nossas chances de construir um mundo melhor aqui e agora, assim como no futuro. Pois a emancipação não pode mais ocorrer sob a lógica da racionalidade moderna, que já provou ser insuficiente para isso (RIBEIRO, 2018, p. 1065).

Desde esta perspectiva, poder-se-á falar em pedagogias insurgentes em vista do "Bem Viver"17 em que movimentos e coletivos sociais têm significativa contribuição para uma existência social que supera a colonialidade do poder.

Ese nuevo horizonte de sentido histórico, la defensa de las condiciones de su propia vida y de las demás en este planeta, ya está planteado en las luchas y prácticas

17 Bem viver é tradução em língua portuguesa da expressão "Buen Vivir”, em espanhol. "Buen Vivir", por sua vez, é tradução do conceito andino de Suma Qamaña ou Sumak Kawsay (nas línguas Aymara e kechwa, respectivamente), que expressa tanto afirmação política dos povos originários, quanto forma de resistência aos modos de vida alheios aos valores e identidades indígenas. 
sociales alternativas de la especie. En consecuencia, en contra de toda forma de dominación / explotación en la existencia social. Es decir, una Des / Colonialidad del Poder como punto de partida, y la autoproducción y reproducción democráticas de la existencia social, como eje continuo de orientación de las prácticas sociales (QUIJANO, 2014, p. 856).

Concepção que rompe com o fetiche trazido pelo modelo liberal de desenvolvimento humano e bem estar da sociedade. Por sua visão plural e coletiva a interculturalidade torna-se alternativa para experiências emancipatórias.

É nesse sentido que a interculturalidade não é compreendida somente como um conceito ou termo novo para referir-se ao simples contato entre o ocidente e outras civilizações, mas como algo inserido numa configuração conceitual que propõe um giro epistêmico capaz de produzir novos conhecimentos e outra compreensão simbólica do mundo, sem perder de vista a colonialidade do poder, do saber e do ser. A interculturalidade concebida nessa perspectiva representa a construção de um novo espaço epistemológico que inclui os conhecimentos subalternizados e os ocidentais, numa relação tensa, crítica e mais igualitária (OLIVEIRA; CANDAU, 2010, p. 27).

Envolve atores e movimentos coletivizados tecendo caminhos orientados para o decolonial, reforçando a ideia compartilhada por Walsh, Oliveira e Candau (2018) de que a interculturalidade

[...] vem se construindo como força política, epistemológica e pedagógica e faz referência às possibilidades de um pensamento crítico a partir dos subalternizados pela modernidade europeia capitalista e um projeto teórico voltado para o repensamento crítico e transdisciplinar, em contraposição às tendências acadêmicas dominantes de perspectiva eurocêntrica de construção do conhecimento (WALSH; OLIVEIRA; CANDAU, 2018, p.3).

Construída "desde abajo" e contrariando radicalmente a colonialidade do poder, a interculturalidade crítica pode responder às demandas produzidas pelos fenômenos sociais globais e, por consequência, insurgir na tarefa de desconstruir para reconstruir, repensar para ressignificar, relacionar-se, interagir, negociar, dialogar e interpelar.

Las pedagogías, en este sentido, son las prácticas, estrategias y metodologías que se entretejen con y se construyen tanto en la resistencia y la oposición, como en la insurgencia, el cimarronaje, la afirmación, la re-existencia y la re-humanización (WALSH, 2013, p. 29).

Por efeito de práticas de lideranças, ativismos, produção e ressignificação da participação político social, o diálogo com a complexidade dos processos formativos e subjetividades, assume que o conhecimento científico moderno não é 
o único capaz de possibilitar compreensão e ação no mundo. Tal qual a ideia defendida por Santos (2008) de que nossas histórias de vida, valores e crenças são prova do nosso conhecimento. Logo, os sentidos atribuídos à nossa história, "àqueles que dão sentido às nossas práticas e que a ciência teima em considerar irrelevante, ilusório e falso" (p. 18), vinculam-se em interlocução com conhecimentos e desconhecimentos produzidos pela ciência moderna.

Mas afinal, qual seria o papel do conhecimento científico? Sua acumulação é para enriquecimento ou empobrecimento da vida prática? É para libertação ou silenciamento?

A perspectiva do pensamento dominante está vinculada à ideia de conhecimentos que podem ser divididos, classificados, determinados e sistematizados por relações e especificações. Formas de aprender e ensinar que consideram conhecimentos que se pretendem utilitários e funcionais em horizontes cognitivos adequados a interesses da sociedade hegemônica. Quando exclusivos e compreendidos como universais, marginalizam, de forma abissal, sujeitos, conhecimentos e tradições. Nas palavras de Santos (2007)

O pensamento moderno ocidental é um pensamento abissal. Consiste de distinções visíveis e invisíveis, sendo que estas últimas fundamentam as primeiras. As distinções invisíveis são estabelecidas por meio de linhas radicais que dividem a realidade social em dois universos distintos: o "deste lado da linha" e o "outro lado da linha" (SANTOS, 2007, p. 71).

Realidade que abarca regulação entre o que é verdadeiro e válido e o que é falso e inválido.

A divisão é tal que "o outro lado da linha" desaparece como realidade, torna-se inexistente e é mesmo produzido como inexistente. Inexistência significa não existir sob qualquer modo de ser relevante ou compreensível [...]. A característica fundamental do pensamento abissal é a impossibilidade da co-presença dos dois lados da linha. O universo "deste lado da linha" só prevalece na medida em que esgota o campo da realidade relevante: para além da linha há apenas inexistência, invisibilidade e ausência não-dialética (SANTOS, 2007, p. 71).

Historicamente, condutas que fixaram como legítimos saberes "deste lado da linha" e ilegítimos saberes do "outro lado da linha". Tudo isso, entretanto, tem sido tensionado. Atores do Sul global, nativos de sociedades estruturalmente desiguais, lideram demonstrações de sensibilidade ao democrático. Desenvolvem mecanismos sociais de resistência em ações coletivas de contestação política para a 
transformação social. Não se tratando de coexistir com o naturalizado ou mesmo realizar o sonho do oprimido em fazer as vezes de opressor, mas um contra movimento para construção de um novo pensamento, um cosmopolitismo subalterno (SANTOS, 2007).

Cosmopolitismo subalterno é a noção exposta por Santos (2002) para alternativas sociais que reconhecem a persistência do pensamento abissal intimamente ligado à injustiça social. Contudo, confrontam a monocultura da ciência moderna no exercício de "expandir o presente e contrair o futuro" (p. 239). Como proposto pelo autor, exercícios de expansão do presente para tornar visíveis experimentações sociais excluídas (sociologia das ausências) e exercícios de contração do futuro, entre experiências e expectativas, para radicalizar possibilidades reais (sociologia das emergências). Ambas as maneiras envolvidas na criação do espaço-tempo necessários para conhecer e valorizar experiências sociais em curso no mundo de hoje, numa perspectiva pós-abissal,

[...] ao dilatarem o presente e contraem o futuro, a sociologia das ausências e a sociologia das emergências, cada uma à sua maneira, contribuem para desacelerar o presente, dando-lhe um conteúdo mais denso e substantivo do que o instante fugaz entre o passado e o futuro a que a razão proléptica o condenou. Em vez de estado final, propõem uma vigilância ética constante sobre o desenrolar das possibilidades, servida por emoções básicas como o espanto negativo que suscita a ansiedade e o espanto positivo que alimenta a esperança (SANTOS, 2002, p. 258).

Neste sentido, afirmam-se as epistemologias do Sul, enquanto um conjunto de intervenções epistemológicas que denunciam a supressão dos saberes levada a cabo ao longo dos últimos séculos (p. 12), e, portanto, valorizam os saberes que resistiram a negações e violências. Perspectivas sobre as quais Santos (2007) debruça suas reflexões e provocações em vias de promoção da justiça cognitiva, por uma ecologia de saberes.

Na ecologia de saberes, enquanto epistemologia pós-abissal, a busca da credibilidade para os conhecimentos não científicos não implica o descrédito do conhecimento científico. Implica, simplesmente, a sua utilização contra hegemônica. Trata-se, por um lado, de explorar a pluralidade interna da ciência, isto é, as práticas científicas alternativas que se têm tornado visíveis através das epistemologias feministas e póscoloniais e, por outro lado, de promover a interação e a interdependência entre os saberes científicos e outros saberes, não científicos (SANTOS, 2007, p. 87).

Essencialmente, trata-se de relacionar conhecimentos ocidentais universalizados à consideração de conhecimentos ancorados nas experiências de grupos sociais que têm sido sistematicamente vítimas de injustiça, opressão e 
destruição causadas pelo capitalismo, pelo colonialismo e pelo patriarcado (SANTOS, 2019, p. 19). Como defende Santos (2008) a valorização do conjunto de saberes e epistemologias outras em articulação com a política em busca do que ele chama de "um conhecimento prudente para uma vida decente", remetendo ao contexto dos debates entre as diferentes dimensões do conhecer, à indissociabilidade entre os conhecimentos e a horizontalidade entre eles. Onde outros saberes, não científicos nem filosóficos, e sobretudo, os saberes não ocidentais, continuam em grande medida, até hoje, fora do debate (SANTOS, 2008).

Pontos chamativos para desnaturalização de processos de modernidade/colonialidade e envolvimento com processos de interculturalidade em sua forma crítica e decolonial. Dessa forma, como afirma Walsh (2013) “la decolonialidad no es una teoría por seguir sino un proyecto por assumir. Es un proceso accional para pedagógicamente andar” (p.67). Proposta que supera reconhecer e tolerar diferenças. Supõe intervir, transformar e reconstruir outras/novas formas de coexistir e conviver, implicadas na valorização de experiências e conhecimentos construídos nos contextos de enfrentamento, tendo presente a perspectiva da interculturalidade.

\subsection{Engajamentos para impulsionar lógicas outras}

Associada a necessidade de intervir e afirmar epistemologias em consideração a pluralidade, admite-se, conforme Oliveira e Candau (2010), que a desigualdade presente na sociedade "não pode ser entendida sem tomar em conta nexos com a herança colonial e as diferenças étnicas que o poder moderno/colonial produziu" (p.23).

$\mathrm{Na}$ esteira de tais considerações, sobretudo, para visibilizar processos pedagógicos situados em trajetórias subalternizadas, a decolonialidade é um compromisso ético e epistêmico de transformação. Afinidade política e pedagógica em relação estreita com cotidianos e trajetórias de conhecimentos locais, nascidos ou aprendidos nas lutas e na ecologia de saberes (SANTOS; MESESES, 2010).

Como dito anteriormente, a pedagogia e o pedagógico aqui defendidos não se limitam ao campo da educação formal e espaços escolarizados, mas acrescentam- 
se movimentos, organizações da sociedade civil, projetos, museus e ações de gritos e grietas como posicionamento de um chamamento radical em vias de favorecer a superação do sistema mundo hegemônico. Grietas, como conceituado por Walsh (20013, 2016), traduz-se por brechas e espaços de possibilidades da práxis e enfrentamento a matriz colonial de poder. Tal qual um espaço a partir do qual a ação militância, resistência, insurgência e transgressão são impulsionadas, onde as alianças se constroem, e surge um modo-outro que se inventa, cria e constrói (p. 72).

Pedagogías que se esfuerzan por abrir grietas y provocar aprendizajes, desaprendizajes y reaprendizajes, desprendimientos y nuevos enganchamientos; pedagogías que pretenden plantar semillas nos dogmas o doctrinas, aclarar y en-redar caminos, y hacer andar horizontes de teorizar, pensar, hacer, ser, estar, sentir, mirar y escuchar — de modo individual y colectivo- hacia lo decolonial (WALSH, 2013, p. 67).

Caminhos pedagógicos considerando os diversos conhecimentos, saberes e fazeres a partir dos gritos que ecoam no e do Sul. Gritos que questionam precariedade e indiferença a qual, por exemplo, a população periférica é submetida. Gritos comprometidos com a liberdade individual e coletiva traduzidos como afirmação democrática.

É um processo dinâmico sempre em processo de fazer-se e refazer-se dada a permanência e capacidade de reconfiguração da colonialidade do poder. É um processo de luta, não só contra, mas ainda mais importante, para -para a possibilidade de um modo-outro de vida. Um processo que engendra, convida a aliança, conectividade, articulação e inter-relação, e luta pela invenção, criação e intervenção, por sentimentos, significados e horizontes radicalmente distintos (WALSH, 2016, p. 72).

Tarefa que não é apenas técnica, mas emocional e que é, simultaneamente, um trabalho intelectual e um trabalho político. Práticas sociais em projetos para emancipação epistêmica. Atitudes coletivizadas em questionamento ao sistema moderno/colonial, conforme provocação de Quijano (2005), um tempo de ações para "deixar de ser o que não somos" (p.139). Formas de trabalho para romper ciclos e desnaturalizar imposições. O trabalho de Walsh (2016) retrata buscas, (re)construções epistemológicas e (re)ações que abarcam

"[...] desaprender a modernidade racional que me (de) formou, aprender a pensar e agir em suas fissuras e brechas, que converteram em parte de minha localização e lugar. São parte integral de como e a partir de que lugar me posiciono. Também são constitutivas de como concebo, construo e assumo minha práxis." (WALSH, 2016, p. 65). 
Expressões de caminhos de luta contínua que podem ser identificadas em narrativas insurgentes, pois o decolonial, como diz Walsh (2016), "não vem de cima, mas de baixo, das margens e das fronteiras, das pessoas, das comunidades, dos movimentos, dos coletivos que desafiam, interrompem e transgridem as matrizes de poder colonial em suas práticas de ser” (p.72).

Uma vez que a interculturalidade se torna um paradigma desejável entendese a perspectiva de forma dinâmica, em caminhos que impulsionam fronteiras (MIGNOLO, 2008). Prioritário, contudo, é estabelecer que não se trata de hierarquizar saberes, mas sobretudo dialogar entre a diversidade e sua capacidade de convocação a situações contra o capitalismo desumanizante. Sendo essencial interculturalizar em propostas de participação e representação pluralista que respeitem origens e dissidências entre pessoas e povos (LÓPES-HURTADO, 2007). Propostas que abarcam a narrativa universal, conectando-se a validade de todos os conhecimentos dado que " todos os povos são considerados vivendo no presente e não no passado da civilização euro/norte-americana (RIBEIRO, 2018, p. 1068).

Sendo assim, dentre lutas e resistências na América Latina nos últimos anos, trabalhos como os de Briseño (2018) e Said (2018) são importantes reflexões para o exercício da interculturalidade. Partindo de elementos como festa, trabalho, poder e território, os jovens de Oaxaca, no México, valorizam realidades e processos formativos nas diversas esferas relacionais da sociedade. $\mathrm{O}$ sentido comunal da experiência expõe dinâmicas insurgentes diante do poder institucional moderno/colonial.

O pensamento de comunalidade permeou esta proposta pedagógica para evidenciar formas de vida e organização diferentes das desenvolvidas por um sistema hegemônico de pensamento de poder colonial. A intenção do Movimento Pedagógico era trabalhar com as comunidades de outra maneira, da sua própria maneira, em suas palavras, buscavam " comunalizar a educação" (BRISEÑO, 2018, p. 4).

Inquietações das novas gerações dos grupos historicamente subalternizados que se organizam para visibilizar biográficas e práticas negligenciadas pelas normatizações universalistas do conhecimento. O que Briseño (2018) denomina micro geopolítica do conhecimento intergeracional para levar a cabo um projeto no sentido comunitário. "São os jovens formados em um pensamento crítico, diante 
não só da colonialidade do conhecimento, mas também do poder, econômico e do ser, que defendem outra forma de escola, baseada no comunalidade" (p.10).

Para Said (2018), a proposta dos Bachilleratos Populares “[...] parte da desocultação da riqueza existente nas correntes pedagógicas da região, da busca das ausências para expandir o presente e da concentração nas emergências para contrair o futuro" (SAID, 2018, p. 10). Segundo o autor,

No marco desses movimentos latino-americanos e de suas novas formas de construção social e política, vastas experiências dissolvem na prática a separação entre educação e política, entre escola e território, incumbindo-se da tarefa de criar e tornar reais novas pedagogias (SAID, 2018, p. 7).

Pequenas amostras que refletem o potencial de atores e coletivos sociais que reconhecem interdependência do debate entre político e social. Um exercício que provoca alargamento à compreensão sobre os processos de empoderamento e consciência, individual e coletiva das juventudes e seus ativismos na busca por soluções junto ao estado e sociedade civil, onde organização e participação em movimentos e manifestações seriam então um canal de extravasamento.

Sobre as formas de manifestação e contestação dos jovens brasileiros, Carrano (2012) afirma que:

[...] a "rebelião da juventude" seria uma resposta possível à crise da sociedade moderna - caracterizada pela não realização das promessas de ascensão social e desenvolvimento - e o movimento estudantil um fenômeno paradigmático dessa rebelião (p.90).

Caminhos de vida em contribuição a saberes-fazeres em consciência de uma nova sociedade que corporifique em práticas sociais, educacionais, culturais e políticas, horizontes democraticamente fortes onde todo fazer tem um saber e todo saber tem um fazer. Práticas pedagógicas de engajamento, reconhecimento, afirmação e transformação. Implicações para valorização de experiências de movimentos e ativistas latinos, nesta investigação localizados em São Gonçalo, região metropolitana do Estado do Rio de Janeiro, e assim "chamar e atenção sobre sua existência e crescente insurgência" (WALSH, 2016, p. 73).

$\mathrm{Na}$ diversidade que forma a juventude brasileira, que experiências constituem seus engajamentos? Tendo em conta que lideranças não se improvisam, sensibilidade ao democrático se ensina? Questões desafiadoras para a problemática aqui investigada. 


\title{
4 Fala e escuta das juventudes gonçalenses: metodologia da pesquisa
}

\author{
“O objetivo não era obter informação adicional, mas sim \\ conhecimentos e perspectivas diferentes" \\ Boaventura Sousa Santos.
}

Neste capítulo compartilho procedimentos e experiências de pesquisar e escutar trajetórias de lideranças juvenis presentes nas periferias urbanas. Justifico escolhas metodológicas e posiciono experiências ao longo da realização deste trabalho que está inserido na inédita situação de recomendação de distanciamento físico em decorrência da pandemia provocada pelo novo coronavírus.

Para análise e valorização de experiências formativas que sensibilizam para engajamento e participação democrática, foi escolhido como objeto de estudo os processos formativos de jovens gonçalenses que atuam no Projeto Ressuscita São Gonçalo. Após breve contextualização das fases desta investigação, descrevo as técnicas adotadas na produção e análise dos dados.

Este estudo, de natureza exploratória e abordagem qualitativa, abrange dados de 12 entrevistados. No conjunto das entrevistas, 11 são com integrantes do Projeto Ressuscita São Gonçalo e 1 com representante da ONG Casa Fluminense. As entrevistas foram transcritas e incluídas no software ATLAS.ti para análise a partir de categorias oriundas de dimensões do vívido nas trajetórias aqui implicadas. Conta também com dados complementares de observação de 3 atividades lideradas pelos jovens. As observações foram registradas em caderno de campo após realização de atividades promovidas pelos jovens na e para a cidade. As fotografias são originais da pesquisa, somadas a fotografias fornecidas pelos participantes. Este capítulo está organizado conforme ocorreram etapas, replanejamentos e decisões da pesquisa.

\subsection{Etapas e processos da pesquisa: aproximação do campo}

O intuito deste estudo está em compreender que saberes e conhecimentos ou ainda que fazeres e ensinamentos estimularam e estimulam a emergência da participação político-social das juventudes presentes no Projeto Ressuscita São Gonçalo. Dentro deste propósito, a abordagem qualitativa se apresenta como a mais 
apropriada porque busca verificar como determinado fenômeno se manifesta nas atividades, procedimentos e interações em seu contexto (GODOY, 1995). Diante desse quadro, como pontuado por Duarte $(2002$, p. 140) a pesquisa qualitativa, "apesar dos riscos e dificuldades que impõe, revela-se sempre um empreendimento profundamente instigante, agradável e desafiador". Assim foram os processos e fases deste trabalho cujo estímulo é compreender fenômenos de engajamento sóciopolítico-culturais das juventudes periféricas.

Para responder as questões de pesquisa expressas anteriormente (seção 1.2), considerei dois instrumentos: visitas de observação e entrevistas.

1. Visitas de observação a espaços e ações sociais promovidas pelos/as jovens. Nas três atividades observadas foram presenciadas interações tanto com o espaço quanto com a cena social. Exercitando a proposta de Oliveira (1996), procurei olhar a partir dos/as jovens e ouvir dos/as jovens elementos que favoreceriam o desenvolvimento deste trabalho. Dessa forma, busquei escrever práticas, intervenções, valores e atitudes individuais e coletivas que contribuíssem com os objetivos do trabalho ou que pudessem ser aprofundadas nas entrevistas e posterior análise.

2. Entrevistas com jovens integrantes do projeto. As entrevistas são aqui entendidas como estratégia de escuta e compreensão dos "indícios de modos como cada um daqueles sujeitos percebe e significa sua realidade (DUARTE, 2004, p, 215).

Conforme indicado por Duarte (2004) a entrevista é uma oportunidade de aprofundar diálogos tal qual "uma espécie de mergulho em profundidade" que permite perceber como cada sujeito representa a realidade em suas trajetórias (DUARTE, 2004). Assim sendo, aproximei-me do campo e das pessoas potencialmente participantes a fim de estabelecer confiança nas interações que ali ocorreriam. A relação estabelecida com os/as jovens passou a ser de direitos e responsabilidades. De minha parte responsabilidade de assegurar e proteger o que a partir daquele momento seria compartilhado com sigilo, confiabilidade, privacidade e respeito. Por parte dos participantes o direito de a qualquer momento ou ocasião de desconforto optarem por não mais participar (TEIXEIRA; OLIVEIRA, 2010) Feito o convite e garantindo-se a participação voluntária, as 
primeiras informações foram reunidas e surgiu uma rede de contatos com os/as jovens que lideram o projeto. Para a etapa das entrevistas seriam convidados/as jovens que participavam da tomada de decisões do grupo.

Ocorre que esta pesquisa aconteceu num momento singular da história, já que durante sua tramitação foi atravessada pela pandemia provocada pelo SARS-CoV2. Por conta disso a etapa das entrevistas e a opção pela observação dos espaços e atividades precisou ser repensada.

SARS-CoV-2 ou Covid-19 é uma doença causada pelo coronavírus, "que apresenta um espectro clínico, variando de infecções assintomáticas a quadros graves" (Ministério da Saúde, 2020). A transmissão do vírus acontece de uma pessoa para outra por gotículas de saliva ou toque em objetos de superfícies contaminadas. Dado o aumento do número de casos e disseminação global a Organização Mundial da Saúde (OMS) a definiu como uma pandemia. Na ocasião da decisão, 11 de março de 2020, mais de 114 nações registravam casos da doença. Uma crise sanitária global que impactou rotinas, expectativas de trabalho, consumo, lazer e convivência.

Diante do quadro da doença em escala global, algumas medidas foram tomadas. Dentre elas a declaração de quarentena e sugestão de auto isolamento. Estratégias para frear contágios e "achatar a curva" do número de casos que alcançou 52.681.305 ${ }^{18}$ (cinquenta e dois milhões, seiscentos e oitenta e um mil, trezentos e cinco) pessoas no mundo até o mês de novembro de 2020. Uma crise de impacto mundial sem precedentes que provocou colapso em sistemas de saúde, horizontes econômicos e perspectivas políticas, aprofundando crises de região para região do Brasil. Como pontuou o sociólogo Boaventura de Sousa Santos na obra "A cruel pedagogia do vírus", "a quarentena não só torna mais visíveis, como reforça a injustiça, a discriminação, a exclusão social e o sofrimento imerecido que elas provocam" (SANTOS, 2020), uma vez que a população historicamente marginalizada foi deslocada ainda mais a margem por esta situação de crise.

A pandemia evidenciou como a má gestão pública afeta acessos a direitos sociais básicos. A conjuntura da formação social capitalista, somada às mudanças provocadas por crises internas e externas, tem favorecido práticas excludentes. São

\footnotetext{
${ }^{18}$ Informação obtida através de consulta ao site https://news.google.com/covid19/map?hl=ptBR\&mid=\%2Fm\%2F02j71\&gl=BR\&ceid=BR\%3Apt-419 em 13 nov. 2020.
} 
inúmeras as causas que contribuíram para que o Brasil acumulasse, de março a novembro de 2020 , mais de $164.281^{19}$ (cento e sessenta e quatro mil, duzentos e oitenta e um) óbitos em decorrência da pandemia. Sendo possível atribuir uma das causas às tomadas de decisões e orientações que evidenciam o Estado não como promotor de democracia, cidadania e vida digna, mas como gestor de mortes.

No Estado do Rio de Janeiro, sobretudo nos municípios da Região Metropolitana do $\operatorname{Estado}^{20}$, que entre suas características marcantes tem grande concentração de favelas e comunidades, o vírus, mesmo invisível, atuou com lupa na exposição das desigualdades sociais e aprofundou a crise de cidade para cidade reforçando o colonialismo e o patriarcado (SANTOS, 2020).

Com ausência de assistência e insistente descaso por parte do poder público, a população residente nas regiões periféricas da capital encontrou apoio em mobilizações e coletivos comunitários. O cenário da pandemia contribuiu para afirmação de ausências e pouca eficiência da ação governamental em nível federal, estadual e municipal para garantia dos direitos civis e sociais. Exemplo de regressão em sua capacidade e dever, mas progredindo com uma pandemia intermitente "[...] subjuga[ndo] a vida ao poder da morte (necropolítica)" (MBEMBE, 2018, p. 71). Ocorrências que reforçam a necessidade de visibilização de tramas e trajetórias que tencionam agendas públicas e atuam em redes de solidariedade com municípios e cidades, becos e favelas.

No âmbito local dos territórios urbanos invisibilizados, projetos e ações da sociedade civil, movimentos e coletivos sociais empenham-se em responder demandas que na verdade devem ser endereçadas ao Estado. É a história, mais uma vez, sendo escrita por quem vive dentro e contra às relações sociais de poder. A situação de pandemia acarretou crises sociais e psicológicas durante praticamente todo ano de 2020. Sem um fim à vista para a pandemia do novo coronavírus a alternativa foi refletir sobre as possibilidades de prosseguir a pesquisa enquanto as restrições estavam em voga (LACERDA; RAMALHO, 2020). Em tempo,

\footnotetext{
19 Informação obtida através de consulta ao site https://news.google.com/covid19/map?hl=pt-BR\&mid=\%2Fm\%2F02j71\&gl=BR\&ceid=BR\%3Apt-419 em 13 nov. 2020.

20 A Região Metropolitana do Estado do Rio de Janeiro é um agrupamento de municípios que fazem limites entre si e complementam-se nos planejamentos e viabilização econômico-financeira. Conforme Lei Complementar nº 184/2018, esta unidade regional é composta pelos Municípios do Rio de Janeiro, Belford Roxo, Cachoeiras de Macacu, Duque de Caxias, Guapimirim, Itaboraí, Itaguaí, Japeri, Magé, Maricá, Mesquita, Nilópolis, Niterói, Nova Iguaçu, Paracambi, Petrópolis, Queimados, Rio Bonito, São Gonçalo, São João de Meriti, Seropédica e Tanguá.
} 
reiterando o propósito de ouvir as juventudes sobre seus processos formativos e motivações para engajamento e participação social, a pesquisa foi replanejada.

Uma vez que as práticas de pesquisa presenciais estavam restritas, foram escolhidas estratégias que aplicadas em ambientes virtuais aproximariam pesquisadora a sujeitos, questões a objetivos, e, sincronicamente, observariam as proposições dos órgãos mundiais de saúde, bem como a integridade de todos/as envolvidos/as.

\subsection{2 Ânimo e mãos à obra no e para o trabalho de campo}

A vida sofreu profundas transformações. Paira na modernidade/colonialidade uma ideia de "novo normal" como expressão das mudanças ocorridas na rotina das pessoas de todo o mundo. De forma intensa e aligeirada novas formas de comunicação, trabalho e relações sociais ocuparam espaços em aplicativos e plataformas virtuais. Como interpela Krenak (2020) o discurso em defesa de uma nova normalidade que banaliza o poder das palavras e da existência, é "coisa de quem acha que a vida é baseada em meritocracia e luta por poder" (p. 6). A realidade da pandemia e o avanço do número de óbitos não deveria se tornar consenso normalizado. Nada está como antes e "tomara que não voltemos a normalidade, pois, se voltarmos, é porque não valeu nada a morte de milhares de pessoas no mundo inteiro" (KRENAK, 2020, p. 6).

Entre buscas e encontros para enfrentar os desafios trazidos pela pandemia, analisei a importância de (re)estabelecer contatos que favoreceriam o encontro com as lideranças que se pretendia entrevistar. Uma vez que a pesquisa havia sido apresentada, a partir da inserção no grupo de mensagens instantâneas do "Desafio do Lixo", acessei estratégias que colaborassem para a etapa de campo da pesquisa. Para avançar no trabalho de campo a primeira realidade identificada foi a necessidade de reunir os/as jovens enquanto grupo de participantes desta investigação e posteriormente prosseguir a etapa das entrevistas. Desta forma, delineou-se um questionário online que configurou o quadro de jovens e a etapa das entrevistas.

Assim, o percurso desta investigação contempla: a) observação em 3 atividades lideradas pelos jovens do Ressuscita São Gonçalo, sendo duas atividades 
presenciais e uma atividade em ambiente online; b) a aplicação de um questionário que referenciou à etapa das entrevistas e c) a realização das entrevistas sob a forma da entrevista compreensiva, ambas estratégias (o questionário e as entrevistas) foram feitos exclusivamente em formato online. A seguir são introduzidos instrumentos e técnicas, assim como o quadro de respondentes que configura o posterior quadro de participantes deste trabalho.

\subsubsection{Observação}

Levando em consideração o interesse em conhecer e compreender dinamismos, formas de organização e ativismo dos jovens que participam desta investigação, três atividades foram observadas. Tendo em vista o contexto de pandemia já situado ao longo deste trabalho, as atividades apresentam-se constantes, porém espaçadas. Entre os elementos que interessavam ser investigados, as observações realizadas buscaram compreender comportamentos, eventos e estratégias com e a partir da realidade pesquisada. As visitas de observação tornaram-se "um contato pessoal estreito do pesquisador com o fenômeno pesquisado" (LÜDKE; ANDRÉ, 1986, p. 26), propiciando leituras significativas a partir do fenômeno de participação social.

Duas das atividades observadas ocorreram presencialmente, nos meses de fevereiro e outubro de 2020, em evento conhecido como "Desafio do Lixo". O referido evento é um encontro organizado para limpeza de parte da área do mangue da cidade de São Gonçalo. Com frequência mensal, o evento acontece desde fevereiro de 2019 na Praia das Pedrinhas, bairro de Boa Vista. A região, que fica às margens da Baia de Guanabara, tem em sua orla grande quantidade de detritos trazidos pelas marés e/ou córregos de esgoto sem tratamento. O evento tem inspiração na etiqueta virtual "\#trashtagchallenge"21 e tem recebido destaque nos jornais locais por publicações fotográficas nas redes sociais virtuais com "antes e depois" do desafio realizado pelos jovens.

\footnotetext{
21 "Trash tag challenge" é uma campanha que acontece mundialmente e desafia jovens e adolescentes "entediados" a movimentarem-se em favor do planeta. No Brasil a campanha ficou conhecida como \#desafiodolixo. Para mais informações sugiro https://razoesparaacreditar.com/desafio-do-lixo-internet/ https://www.osaogoncalo.com.br/geral/59392/desafio-do-lixo-tem-2-edicao-na-praia-daspedrinhas-em-sao-goncalo. Acessado em 03 jan. 21.
} 
A terceira atividades observada ocorreu em ambiente virtualizado. Sob proposta de organização de um laboratório para pesquisas e análises sobre impactos do Covid-19 em São Gonçalo, as observações ocorreram em ambiente virtualizado, em reuniões via plataforma Google Meeting, no período de abril a agosto de 2020. O "Laboratório de Análises do Covid-19 em São Gonçalo" é uma iniciativa dos jovens que lideram o Projeto Ressuscita São Gonçalo. Mediante convite compartilhado em redes sociais virtuais e aplicativos de mensagens, o "Laboratório de Análises do Covid-19 em São Gonçalo" reuniu munícipes voluntários interessados em discutir possibilidades e ações em favor da cidade diante das crises derivadas pela pandemia do novo coronavírus.

As atividades observadas foram reconhecidas em suas complexidades entre o espaço real e virtual. Adversidades sobre acesso a tecnologias e internet em realidades de escassez, tanto em instrumentos quanto em precariedades no acesso às Tecnologias da Informação e Comunicação (TICs), exigindo não somente a capacidade de ver e registrar, mas um exercício desafiante diante das circunstâncias de fazer pesquisa com jovens periféricos em cenário de pandemia. Neste sentido, pretendeu-se estabelecer contato pessoal e reconhecimento de relações entre os participantes e seus engajamentos. Sobre estas ações, Lüdke e André (1986) afirmam que

$\mathrm{Na}$ medida em que o observador acompanha in loco as experiências diárias dos sujeitos pode tentar apreender a sua visão de mundo, isto é, os significados que eles atribuem a realidade que os cerca e as suas próprias ações (LÜDKE; ANDRÉ, 1986, p. 26).

Dessa forma, além de gradual relação com o contexto a ser pesquisado, as atividades observadas conferiram prática e densidade à perspectiva do olhar atencioso a descrições e reflexões analíticas contidas no diário de campo. Observar os/as jovens em ação social em bairros da cidade e/ou engajamento virtualizado para a cidade permitiu que a pesquisa chegasse mais perto da perspectiva dos sujeitos sobre seus engajamentos e motivações para participação social. Fato não somente agregador à investigação, mas sobremaneira à pesquisadora, uma vez que fui incluída nas formas de colaboração com as atividades lideradas pelas juventudes participantes.

As interações colaboraram como uma espécie de imersão cultural e promoção de vínculo que, em certo sentido, considera as reflexões de Santos (2019) sobre as 
experiências profundas que acompanham pesquisar. As leituras a partir do autor se colocam como possibilidade de interação e cooperação com e a partir de "corpos (que) sentem e são sentidos em contexto" de pesquisa (SANTOS, 2019, p. 243). Ocorrendo exercitar os sentidos para a importância de pesquisar e ser-com. De maneira que observar e "estar lá" permitiu captar contextos mobilizados e igualmente partilhar vida e lutas enquanto pesquisadora e gonçalense. Estar com os/as jovens representou não somente a ocasião de descrever sujeitos, reconstruir diálogos, localização e comportamentos, mas sensibilidade ao estranhamento causado pelo interesse da pesquisa nas juventudes gonçalenses e de onde deriva minha relação pessoal com a cidade. Refere-se sobretudo de incluir reflexões sobre a variedade de interações, dilemas e conflitos para esclarecimentos convenientes sobre os interesses da pesquisa, tendo presente a realidade de pesquisadora e "cria" da cidade.

\subsubsection{Questionário}

Notadamente o questionário é um instrumento reconhecido para situações de necessidade de alcance a pessoas em situação de dispersão geográfica (GIL, 2008). Para este trabalho o questionário assumiu dupla função: reunir os/as jovens como participantes da pesquisa e configurar o corpus de entrevistados/as. Opções que implicaram capacidade dialógica e criativa para ouvir o cotidiano dos participantes. Por tais escolhas, foi elaborado um formulário online que caracterizasse o grupo e evidenciasse àqueles que atendiam ao critério estabelecido para prosseguir para etapa de entrevista. Ou seja, jovens que participavam das reuniões de tomada de decisões do Projeto Ressuscita São Gonçalo.

O questionário (apêndice 8.2) foi elaborado com perguntas fechadas e abertas, algumas de preenchimento facultativo e outras de preenchimento obrigatório. Apresentei objetivos e a importância do estudo, bem como o caráter voluntário e sigiloso da investigação. Ordenei perguntas sobre escolaridade, idade, autodeclaração racial, bairro de residência, experiências de voluntariado em projetos sociais e/ou coletivos, experiências de trabalho remunerado e adicionei a questão chave para indicação dos jovens convidados/as para a etapa de entrevistas. 
A questão, de resposta obrigatória, tinha como foco a participação no Projeto Ressuscita São Gonçalo.

Conforme figura a seguir, àqueles que declarassem "participo dos encontros de planejamento e tomada de decisões" seriam convidados/as para a etapa seguinte da investigação.

\section{Que atividades do Projeto Ressuscita São Gonçalo você costuma participar? \\ Marque uma ou mais opções \\ Participo dos encontros para planejamento e tomada de decisões \\ Participo compartilhando o conteúdo produzido pelo Projeto nas mídias sociais \\ Participo das ações sociais que o projeto organiza e incentiva}

Figura 1 - Exemplo de pergunta obrigatória do questionário online desta pesquisa Fonte: Elaborado pela autora

Anterior ao compartilhamento com os/as jovens, o link do questionário foi submetido a um pré teste. Uma versão preliminar foi compartilhada com a professora orientadora deste trabalho e dois jovens, uma do sexo feminino e um do sexo masculino, de 22 e 25 anos respectivamente. Exercício significativo para adequação da quantidade de questões e verificação sobre a compreensão delas. Em seguida, via aplicativos de mensagem instantânea, o questionário foi compartilhado com contatos estabelecidos à época da primeira aproximação com o campo, em fevereiro de 2020. O uso de tecnologias digitais foi fundamental, uma vez que reuniu o grupo de jovens que receberiam o questionário e, por outro lado, "permitiu que as pessoas respondessem quando julgaram mais conveniente" (GIL, 2008, p. 122), manifestando, inclusive, respeito a nova rotina imposta pela pandemia.

O link do formulário online foi compartilhado com 27 (vinte e sete) jovens. O endereço virtual permaneceu disponível para preenchimento durante os meses de junho e julho de 2020. Durante este período o questionário alcançou 20 (vinte) respondentes. Dentre os 20 (vinte) respondentes, 13 (treze) declararam participar dos encontros para planejamento e tomada de decisões grupo. Assim, com base no critério estabelecido, configurou-se, o grupo de jovens lideranças a serem entrevistadas. 


\begin{tabular}{|c|c|}
\hline \multicolumn{2}{|r|}{$\begin{array}{l}\text { Quadro } 1 \text { - Jovens do Projeto Ressuscita São Gonçalo que declaram } \\
\text { participação nos encontros de planejamento e tomada de decisões }\end{array}$} \\
\hline Idade & Relação de participação no Projeto Ressuscita São Gonçalo \\
\hline 24 & $\begin{array}{l}\text { Está nos encontros de planejamento e tomada de decisões, participa das ações } \\
\text { sociais que o projeto organiza e compartilha nas mídias sociais o conteúdo } \\
\text { produzido pelo projeto. }\end{array}$ \\
\hline 30 & Está nos encontros de planejamento e tomada de decisões. \\
\hline 45 & $\begin{array}{l}\text { Está nos encontros de planejamento e tomada de decisões, participa das ações } \\
\text { sociais que o projeto organiza e compartilha nas mídias sociais o conteúdo } \\
\text { produzido pelo projeto. }\end{array}$ \\
\hline 26 & $\begin{array}{l}\text { Está nos encontros de planejamento e tomada de decisões, participa das ações } \\
\text { sociais que o projeto organiza e incentiva. }\end{array}$ \\
\hline 23 & $\begin{array}{l}\text { Está nos encontros de planejamento e tomada de decisões e compartilha nas } \\
\text { mídias sociais o conteúdo produzido pelo projeto. }\end{array}$ \\
\hline 20 & $\begin{array}{l}\text { Está nos encontros de planejamento e tomada de decisões e compartilha nas } \\
\text { mídias sociais o conteúdo produzido pelo projeto. }\end{array}$ \\
\hline 24 & Está nos encontros de planejamento e tomada de decisões. \\
\hline 25 & Está nos encontros de planejamento e tomada de decisões. \\
\hline 23 & Está nos encontros de planejamento e tomada de decisões. \\
\hline 23 & $\begin{array}{l}\text { Está nos encontros de planejamento e tomada de decisões, participa das ações } \\
\text { sociais que o projeto organiza e compartilha nas mídias sociais o conteúdo } \\
\text { produzido pelo projeto. }\end{array}$ \\
\hline 23 & $\begin{array}{l}\text { Está nos encontros de planejamento e tomada de decisões e compartilha nas } \\
\text { mídias sociais o conteúdo produzido pelo projeto. }\end{array}$ \\
\hline 22 & $\begin{array}{l}\text { Está nos encontros de planejamento e tomada de decisões e compartilha nas } \\
\text { mídias sociais o conteúdo produzido pelo projeto. }\end{array}$ \\
\hline
\end{tabular}

Fonte: Elaborado pela autora

Dentre os/as 13 (treze) jovens que atenderam ao critério para integrar a etapa de entrevistas, um ponto que mereceu ser considerado é a declaração etária de 2 (dois) respondentes, respectivamente, 30 (trinta) e 45 (quarenta e cinco) anos. Idade posterior à faixa de 15 a 29 anos de idade conforme institui o Estatuto da Juventude $^{22}$. Ainda assim, considerei que ouvi-los seria interessante para o trabalho,

${ }^{22}$ Segundo o que diz o texto da Lei 12.852/2013:

Art. $1^{\circ}$ Esta Lei institui o Estatuto da Juventude e dispõe sobre os direitos dos jovens, os princípios e diretrizes das políticas públicas de juventude e o Sistema Nacional de Juventude - SINAJUVE.

$\S 1^{\circ}$ Para os efeitos desta Lei, são consideradas jovens as pessoas com idade entre 15 (quinze) e 29 (vinte e nove) anos de idade. 
uma vez que se declararam participantes dos encontros de planejamento e tomada de decisões e esta investigação pretendeu focalizar trajetórias formativas das lideranças localizadas no Projeto Ressuscita São Gonçalo.

Em acréscimo, considerei importante entrevistar um representante da ONG Casa Fluminense, uma vez que sua frente de trabalho e apoio se relaciona com o Projeto Ressuscita São Gonçalo. Procurei assim, como afirma Kaufmann (2013), na entrevista sob a forma compreensiva, mais do que constituir uma um grupo de participantes, escolher bem os informantes.

\subsubsection{Entrevista}

Nestas condições, avancei para contato telefônico. No decorrer desta tarefa, dentre os 13 (treze) participantes contatados, 2 (dois) jovens não aceitaram o convite à etapa das entrevistas e foram respeitados em suas decisões. Dessa forma, prosseguiram à etapa de entrevistas ${ }^{23}$ :

- Daniele, mulher, negra, 24 anos, reside no bairro do Boaçú na cidade de São Gonçalo (SG), estudante do Ensino Superior no curso de Geografia da Pontifícia Universidade Católica do Rio de Janeiro (PUC-Rio), bolsista Pibid (Programa Institucional de Bolsas de Iniciação à Docência);

- Rodrigo, homem, negro, 30 anos, reside no bairro do Gradim (SG), Ensino Médio Completo, pai, consultor de comunicação;

- Valda, mulher, branca, 45 anos, reside no bairro de Nova Cidade (SG), mãe, Graduada em Letras na Universidade Estadual do Rio de Janeiro, Campus São Gonçalo - Formação de Professores (UERJ-FFP), Mestra em Língua Portuguesa na UERJ Campus Maracanã, professora e analista de educação;

- Gisele, mulher, parda, 26 anos, reside no bairro de Porto da Pedra (SG), Graduada em Nutrição na Universidade Federal Fluminense (UFF), Especialista em Saúde Pública pela Fundação Oswaldo Cruz (Fiocruz), não exerce atividade remunerada;

\footnotetext{
${ }^{23}$ Em preservação aos sujeitos deste trabalho os codinomes são fictícios.
} 
- Graciele, mulher, parda, 23 anos, reside no bairro de Colubandê (SG), estudante do Ensino Superior no curso de Administração do CEDERJ (Centro de Educação Superior a Distância do Estado do Rio de Janeiro) polo UFRRJ (Universidade Federal Rural do Rio de Janeiro), não exerce atividade remunerada;

- Luana, mulher, branca, 24 anos, reside no bairro de Pita (SG), Graduada em Ciência Ambiental na UFF, sem colocação no mercado de trabalho, produz e comercializa cadernos artesanais;

- Angelo, homem, branco, 25 anos, reside no bairro do Antonina (SG), Ensino Médio Completo, não exerce atividade remunerada;

- Rafael, homem, pardo, 23 anos, reside no bairro de Porto da Madama (SG), estudante no curso de Gestão Pública para o Desenvolvimento Econômico e Social na Universidade Federal do Rio de Janeiro (UFRJ), gestor de projetos;

- Helaine, branca, 24 anos, reside no bairro do Boaçú (SG), estudante no curso de Arquitetura e Urbanismo na UFRJ, não exerce atividade remunerada;

- Aline, parda, 23, anos, reside no bairro de Pacheco (SG), estudante no curso de Engenharia de Produção na UFF, estagiária;

- Paola, preta, 22 anos, reside no bairro do Centro (SG), estudante do Ensino Superior no curso de Gestão Pública para o Desenvolvimento Econômico e Social na UFRJ, bolsista de Iniciação Científica.

Seguido da assessora de mobilização da Casa Fluminense.

- Valéria, mulher, branca, 31 anos, reside no bairro Engenho do Porto na cidade de Caxias, estudante do curso de Doutorado em Antropologia na UFF, Mestra em Antropologia pela UFF, Graduada em Ciências Sociais pela UFRJ, coordenadora do curso de Políticas Públicas e do Fundo de Apoio a projetos sociais.

As entrevistas foram agendadas em horários conforme possibilidade dos participantes. Por aplicativo de mensagem instantânea, enviei o Termo de 
Consentimento Livre e Esclarecido ${ }^{24}$ seguido do link de acesso a sala virtual. As entrevistas foram realizadas através da plataforma Google Meet com áudio, gravação captada pelo software Cantasia. A etapa de entrevistas ocorreu entre os meses de julho e agosto de 2020. As 12 (doze) entrevistas (11 lideranças e 1 representante da Casa Fluminense) e respectivos termos de consentimento estão armazenados em espaço virtual e serão mantidos por 5 anos sob guarda da autora.

Por instabilidades no sinal de internet, algumas entrevistas foram momentaneamente interrompidas. Quando muito, foi combinado no início das entrevistas que as falas dos/das jovens seriam privilegiadas, dessa forma, em algumas vezes, fechei minha câmera enquanto tentativa de estabilizar a conexão. Não posso deixar de compartilhar que em uma das entrevistas fui surpreendida pela falha na captação do áudio e a entrevista precisou ser remarcada. Não foram poucos os desafios apresentados na fase da pesquisa de campo virtualizado. Como solução conectei uma caixa de som externa para favorecer as condições de gravação. Aproveitei que "no meio do caminho tinha uma pedra" e somei aos materiais descritos gravação de voz via telefone celular, afim de não mais tropeçar e garantir a gravação dos encontros virtuais.

Dentre os empenhos, mostrou-se fundamental o exercício de buscar um fluxo natural e dinâmico para as entrevistas. A busca foi compreender, tal qual nos apresenta Santos (2019) que

Os contextos não são armazéns de sentidos e de sensações prontos a serem usados. Alteram a identidade dos que sentem e dos que são sentidos. Os corpos sentem e são sentidos em contextos. Alguns contextos mais complexos que outros (SANTOS, 2019, p.243).

Como seria de se esperar, na complexidade do contexto vivido por ocasião da pandemia, as entrevistas iniciavam com tentativas de quebrar o gelo, situadas no cotidiano das imposições do vírus. São Gonçalo, cidade em que foi realizado este trabalho, acumulava à época número alto de casos suspeitos de contaminação pelo coronavírus, busquei ouvir os participantes sobre temas da saúde e familiares, o que implicada em ir além da coleta de dados. Mas compreendendo que:

A atitude de simpatia em relação à pessoa, e a tentativa de descoberta das categorias que estão no centro de seus sistemas de pensamento e de ação, não constituem dois elementos separados. O pesquisador começa por um papel de composição: ele é

\footnotetext{
${ }^{24}$ Por ocasião do distanciamento físico, solicitei que registrassem em áudio o consentimento e aceite à pesquisa. $\mathrm{O}$ arquivo me foi enviado via aplicativos de mensagem instantânea e permanecerá arquivado em drive virtual de posse da autora pelos próximos 5 (cinco) anos.
} 
gentil, receptivo e acolhe muito positivamente tudo o que é dito. É um instrumento que o faz entrar no mundo do informante (KAUFMANN, 2013, p. 85).

Reconheço como prática fundamental a elaboração de um roteiro semiestruturado (apêndice 8.4 e 8.5). No caso desta pesquisa, o roteiro foi organizado em blocos temáticos de infância, família, escolaridade, experiências de trabalho e participação em projetos sociais. Além de apoio, trouxe segurança e permitiu maior clareza sobre onde incluir questões que pudessem aprofundar as declarações dos respectivos questionários e observações das atividades. Tal como afirmação de Kaufmann (2013, p.16) que "são nas situações de maior intensidade, mas notadamente de maior naturalidade, na interação em campo, que se revelam as camadas mais profundas de verdade"

Por esta organização encontrei condições de refletir sobre o que é periférico e contribui com a investigação, entre o que parecia superficial. Assim, procurar identificar a situação mencionada por Kaufmann (2013, p. 81) sobre a atenção a melhor pergunta que não está posta, mas deve ser encontrada a partir do que acaba de ser dito pelo informante. Em diálogo recíproco a partir das posições que ambos os interlocutores ocupam na situação específica de entrevista (de interrogador e de respondente), dando lugar a um campo de possibilidade de improvisação substancialmente alargado quer nas questões levantadas, quer nas respostas dadas (FERREIRA, 2014 p. 982), que não categoriza de forma estática ou acumula informações, mas conhece, compreende e compartilha teorias (re)construídas no campo.

\subsection{Análise do material}

O processo para análise de dados do presente estudo foi elaborado investigando contextos, características e situações que acompanharam as interações e mensagens em observações e entrevistas, respectivamente. Acompanhou todo processo da pesquisa de campo o exercício de refletir com e a partir das relações entre contexto e conteúdo das mensagens produzidas, bem como aspectos exteriores a elas.

Neste sentido, após etapa de organização das transcrições das entrevistas e adição dos documentos no ATLAS.ti, iniciei a leitura do material. A etapa das 
leituras, no plural, foi importante ponto de aprofundamento da realidade contextual dos relatos. Em seguida, considerei adequado substanciar de forma aprofundada e criativa o que percebi nos arquivos destacando diálogos e inserindo notas explicativas sobre as interações. De acordo com as leituras em Kaufmann (2013) este processo de aprofundamento imaginativo é um exercício que permite ir além do conteúdo e tende a conferir volume ao objeto uma vez que

o resultado não depende do conteúdo, simples matéria prima, mas da capacidade analítica do pesquisador. $\mathrm{O}$ tratamento não consiste em simplesmente extrair o que está nas gravações e ordená-lo. Ele toma forma de uma verdadeira investigação, aprofundada, ofensiva e imaginativa: é preciso fazer os fatos falarem, encontrar indícios, se interrogar a respeito da mínima frase (KAUFMANN, 2013, p.119).

Kaufmann (2013) afirma ainda que para a análise de conteúdo não se pode esperar uma sobreposição de etapas e utilização de técnicas, mas especial atenção a construção do objeto em que emergem as categorias desde as mais humildes e ordinárias à mais legítima e nativa. Entre leituras e processos para análise do material, dois aspectos foram recorrentes: memórias afetivas e reinterpretações propositivas. A partir desta percepção sobre os processos formativos dos/as jovens retornei aos documentos e exercitei identificar temas que se apresentam-se dentro destes aspectos.

Reconhecendo a recorrência de memória afetiva e reinterpretação propositiva, o ouvido ficou mais atento e a investigação do material avançou. Com base na chave de leitura de saberes-fazeres por memória afetiva e saberes-fazeres por reinterpretação propositiva, agrupei em 4 (quatro) categorias as dimensões mais recorrentes nos relatos dos/das participantes.

Pode-se dizer que por memória afetiva os relatos comunicam dimensões de: 1) perceber-se nas incertezas de viver uma realidade de precariedades em ocasião as desigualdades sociais presentes na periferia; 2) encontros com a diversidade a partir da realidade em que se está inserido socialmente como afirmação de si e do direito à vida digna.

Por reinterpretação propositiva comunicam: 3) perspectivas em ação de transformação uma vez que reconheceram demandas sociais como educação, habitação e saúde; 4) microuniversos insurgentes que decorrem de experiências sociais variadas expressas em representação, ocupação e resistência. 
No capítulo "Fala juventude: análise e discussão dos resultados" descrevo de forma detalhada a configuração de cada categoria e relaciono-as teoricamente para interpretação do material. 


\title{
5 Fala juventude: análise e discussão dos resultados
}

\author{
"Chega de esculachar a população. \\ Chega de matar nossos jovens." \\ Marielle Franco
}

Neste capítulo são apresentados os dados que foram produzidos a partir do trabalho de campo. A opção metodológica possibilitou mapear experiências, realidades e objetivos que perpassam a vida das juventudes gonçalenses. A partir da produção destes dados buscou-se reconhecer e compreender saberes e fazeres que estariam mobilizando os/as jovens em seus engajamentos e ativismos sociais.

Num primeiro momento compartilho notas das observações de três atividades desenvolvidas pelos jovens participantes do Projeto "Ressuscita São Gonçalo”. A partir da entrada em campo, apresento informações sobre o projeto Ressuscita São Gonçalo e sua conexão com a Casa Fluminense. Em seguida são agrupadas as informações do questionário para breve configuração dos participantes. Por fim seguem-se análise e discussão dos resultados das falas dos 11 jovens entrevistados/as.

Percebendo-se a complexidade de significados gerados a partir das narrativas dos jovens participantes, para melhor visibilizá-las, organizei os relatos em dois aspectos: memórias afetivas e reinterpretação propositiva. Dessa forma, a partir dos aspectos mais recorrentes de memórias afetivas e reinterpretação propositiva, foram construídas quatro categorias: perceber-se nas incertezas; encontros com a diversidade geográfica, humana e social; perspectivas em ação e microuniversos insurgentes que serão evidenciadas através de citações extraídas dos depoimentos dos/das jovens.

\subsection{Notas das observações}

No decorrer da investigação registei os encontros com os/as jovens que participam do projeto Ressuscita São Gonçalo. As anotações estão em caderno de campo assim nomeadas: Desafio do Lixo - fevereiro, Laboratório de Análise do Covid -19 - maio/agosto e Desafio do Lixo - outubro. As notas de campo foram elaboradas durante e após atividades e revelaram-se bastante significativas. 
O "Desafio do lixo" é uma das atividades lideradas pelos jovens do Projeto Ressuscita São Gonçalo e foi ponte para apresentação, estabelecimento de vínculo e realização deste trabalho. O "Desafio do lixo" é um encontro aberto a qualquer pessoa que queira participar. Gonçalenses de todas as idades e bairros da cidade são convidados a participar da limpeza de parte da região do mangue da cidade. No decorrer da pesquisa outra atividade observada foi o "Laboratório de Análise de Covid-19”. Esta atividade é uma iniciativa virtualmente organizada para pesquisar e analisar possíveis impactos da pandemia na cidade de São Gonçalo.

Como dito anteriormente, no acompanhamento às atividades foram organizadas notas em um caderno de campo com o intuito de auxiliar posteriormente na análise da atuação dos jovens a partir dessa observação feita em atividades reais promovidas por eles. Lidas e resumidas, as anotações assumem formas de aproximação, estreitando inquietudes e encontros.

\subsubsection{Aproximação}

Em fevereiro de 2020 realizou-se $12^{a}$ edição do "Desafio do Lixo". O evento foi divulgado nas redes sociais virtuais do grupo. Avaliei a ocasião como oportunidade de encontro para apresentação da pesquisa. Considerando a importância de aproximação e vínculo com campo e sujeitos, explicitei o interesse em estudar as juventudes e suas motivações para engajamento social. Tão logo fui interpelada sobre minhas motivação e origem de tal investigação, encontrando nesta abertura chance de explicitar condições concretas que motivam este trabalho, como o fato de residir a cidade de São Gonçalo e reconhecer tanto contradições quanto potencialidades da cidade.

Estavam presentes, cerca de 15 jovens interessados/das em cuidar, limpar e preservar a área do mangue da cidade. Alguns, inclusive, participando pela primeira vez. Na figura 2 localizo, em vermelho, a região da Praia das Pedrinhas, bairro de Boa Vista onde está o mangue, às margens da Baia de Guanabara. As figuras 3 e 4 são registros da área do mangue da edição de abril de 2019. 


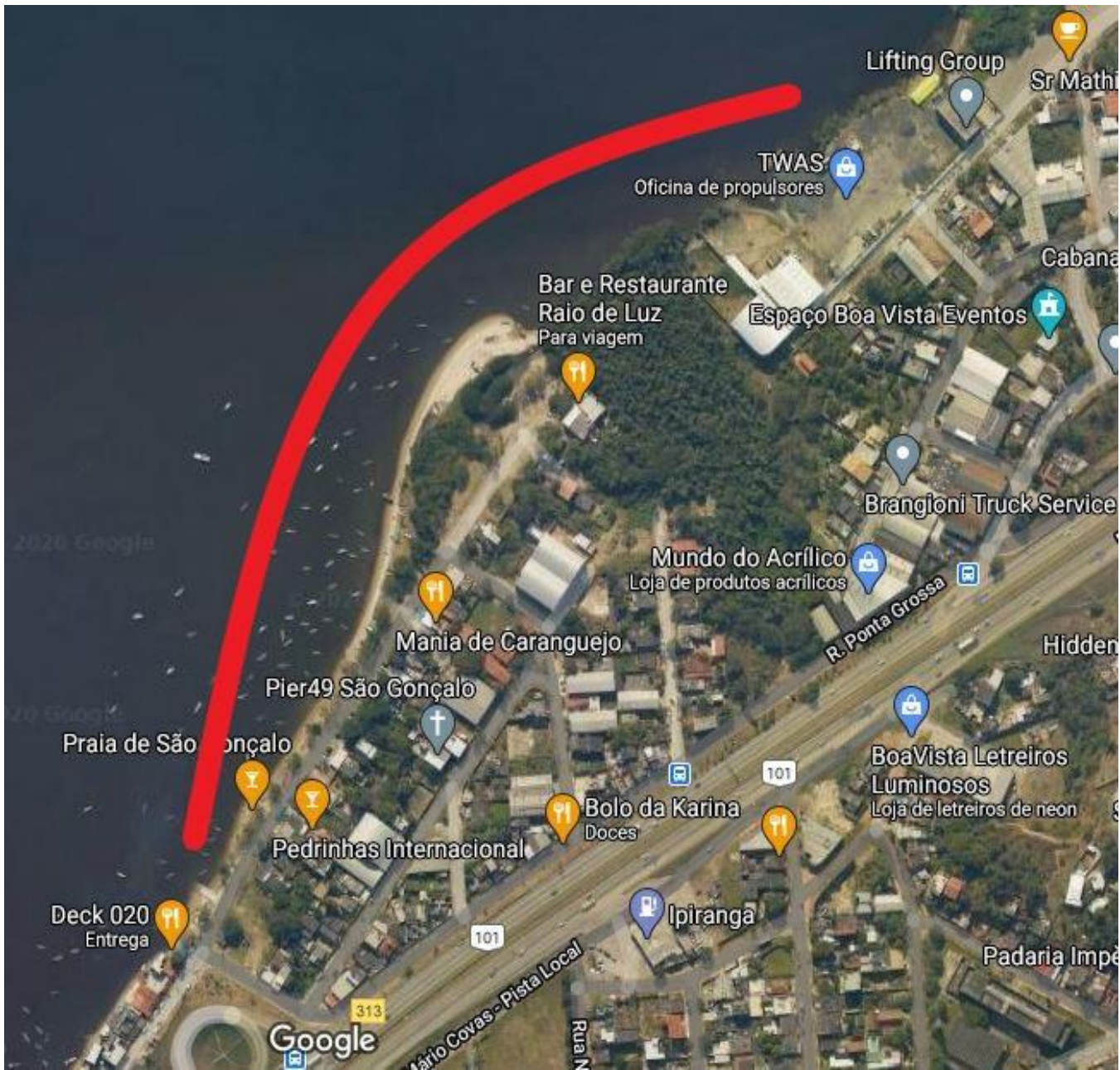

Figura 2 - Área da Praia da Pedrinhas, Boa Vista São Gonçalo.

Fonte: Google Maps, 2020 


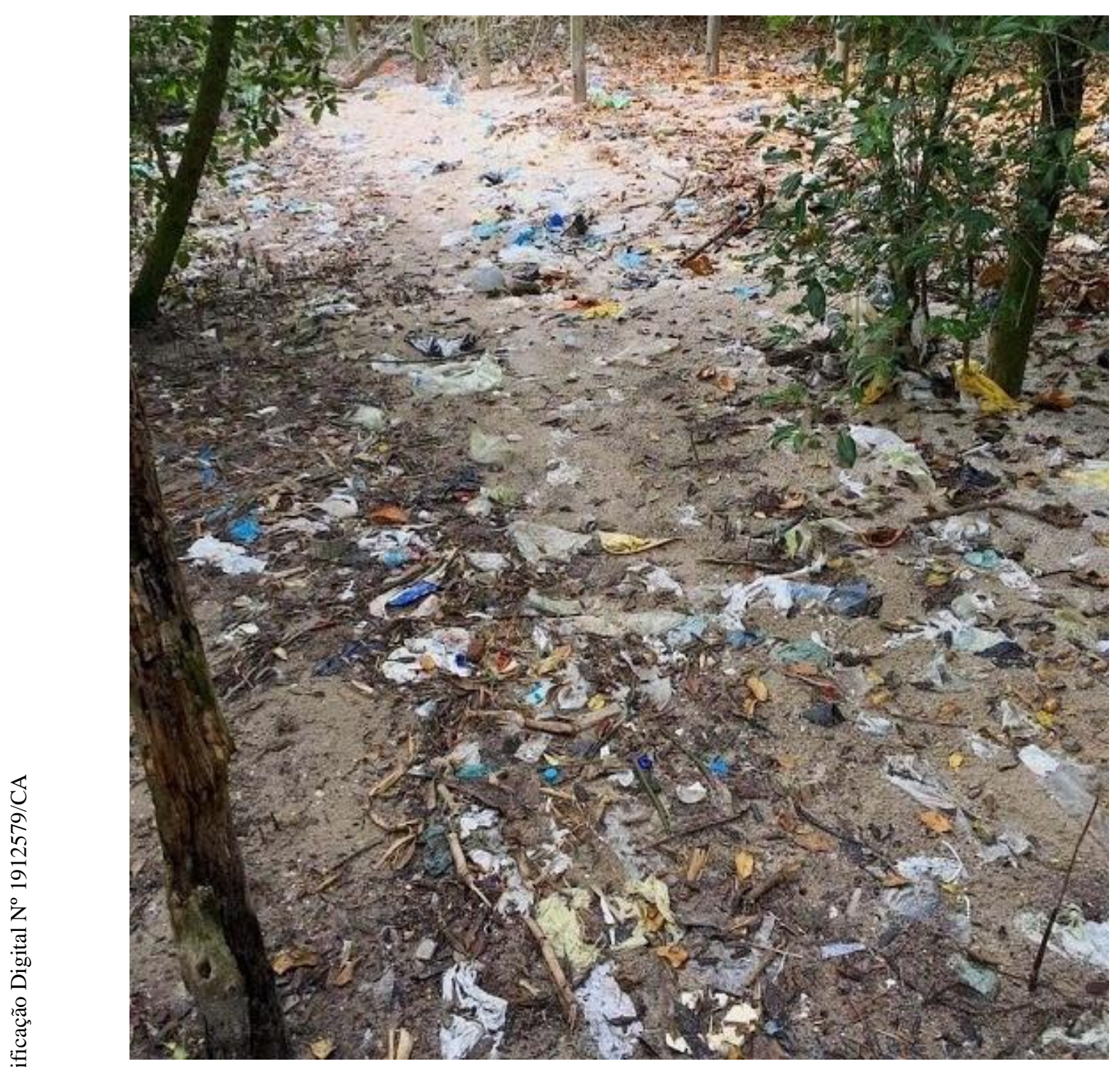

Figura 3 - Desafio do Lixo, edição abril/2019.

Fonte: Projeto Ressuscita São Gonçalo 


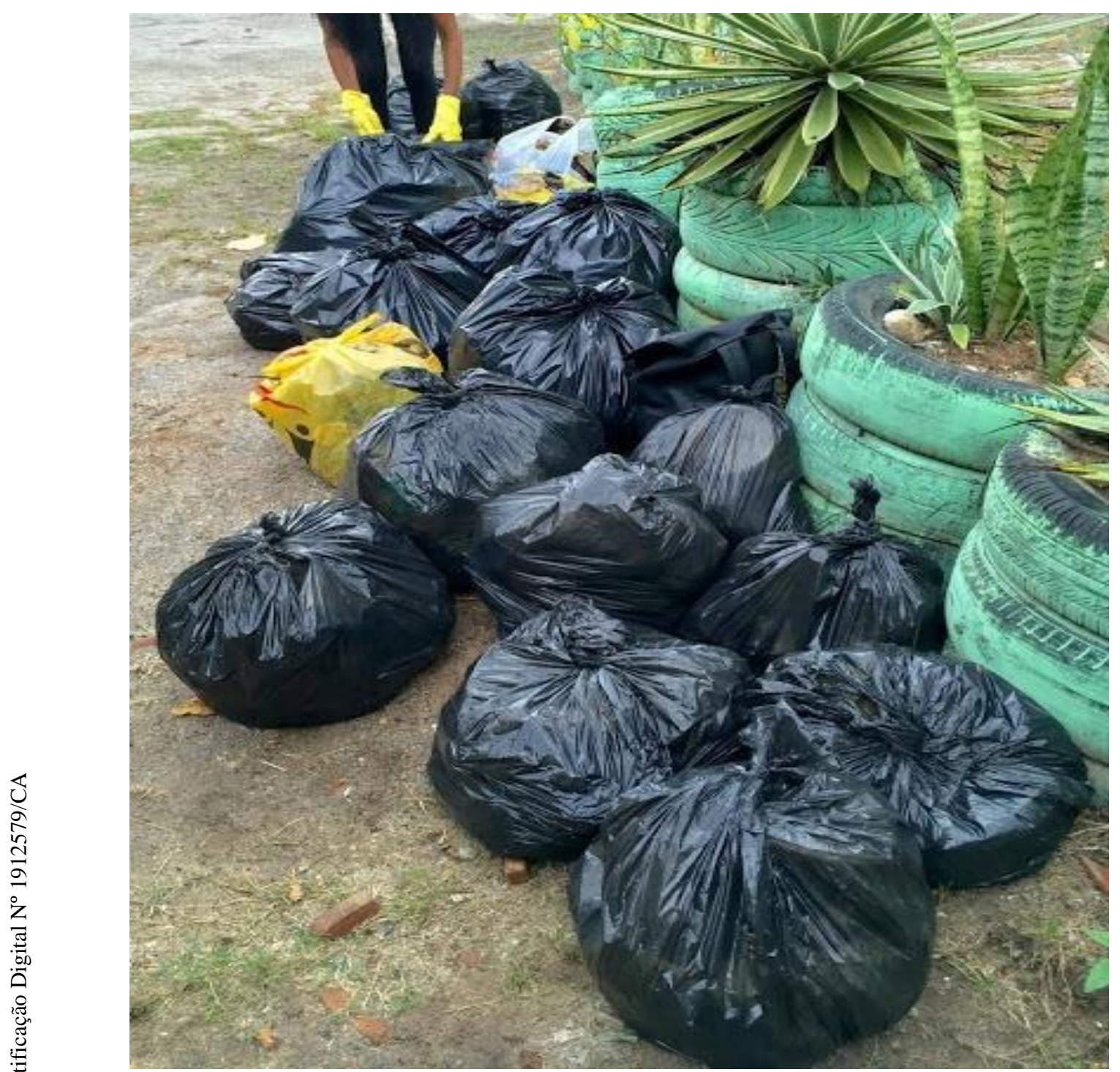

Figura 4 - Desafio do Lixo, edição abril/2019.

Fonte: Projeto Ressuscita São Gonçalo

Com início em 2019, o evento acontece nas tardes do $2^{\circ}$ (segundo) sábado de cada mês, às $14 \mathrm{~h}$. A figura 5 foi registrada na ocasião da edição de fevereiro de 2020. Destaca-se a paisagem registrada na figura 5 em oposição a figura 3. A alegria pelo feito coletivizou-se. Sol, carnaval e jogo de futebol apresentavam-se nos diálogos, mas sobressaia a resposta que a natureza oferecia conforme figuras 6 e 7 . 


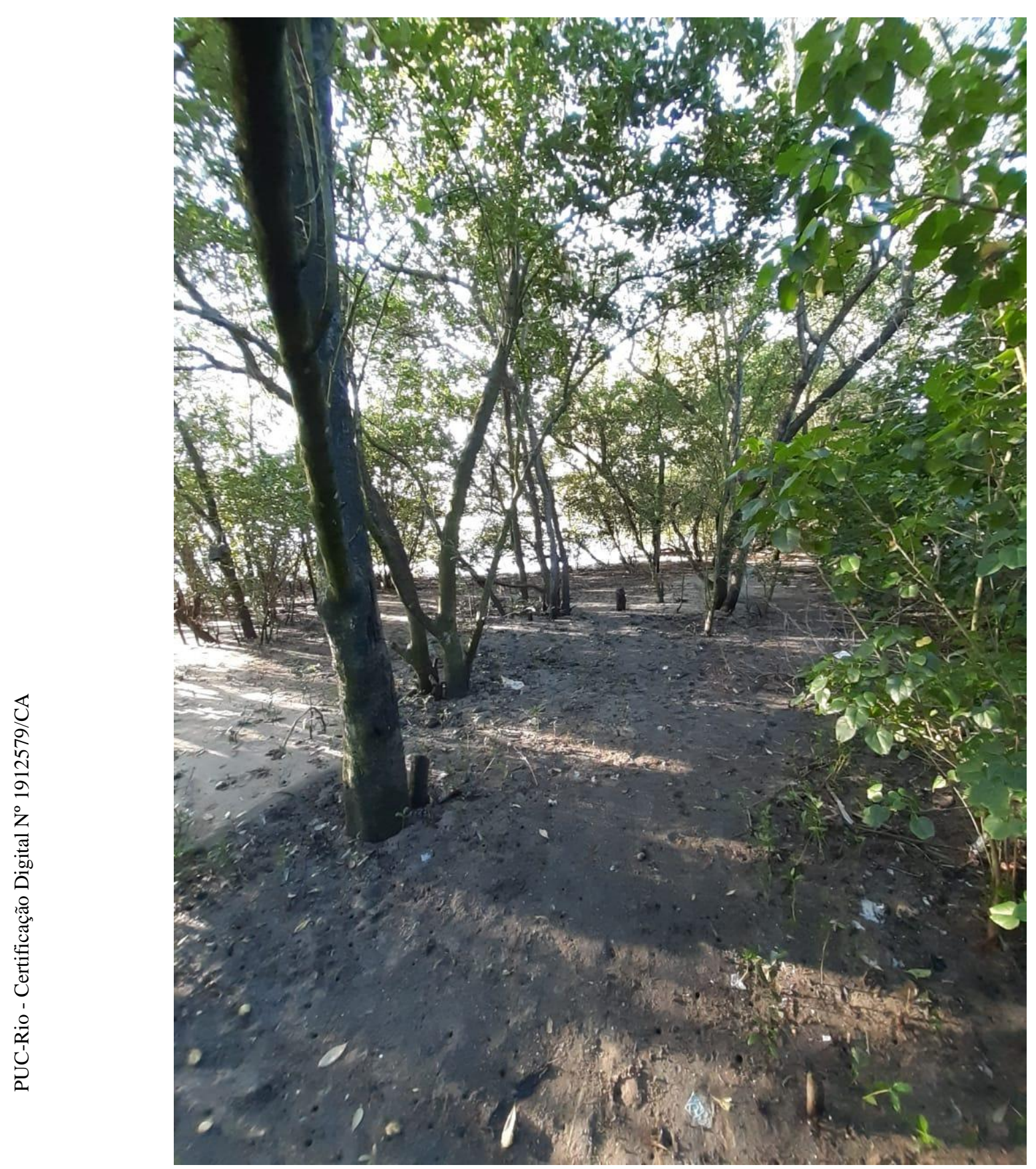

Figura 5 - Desafio do Lixo, edição fevereiro/2020.

Fonte: Registro da autora 


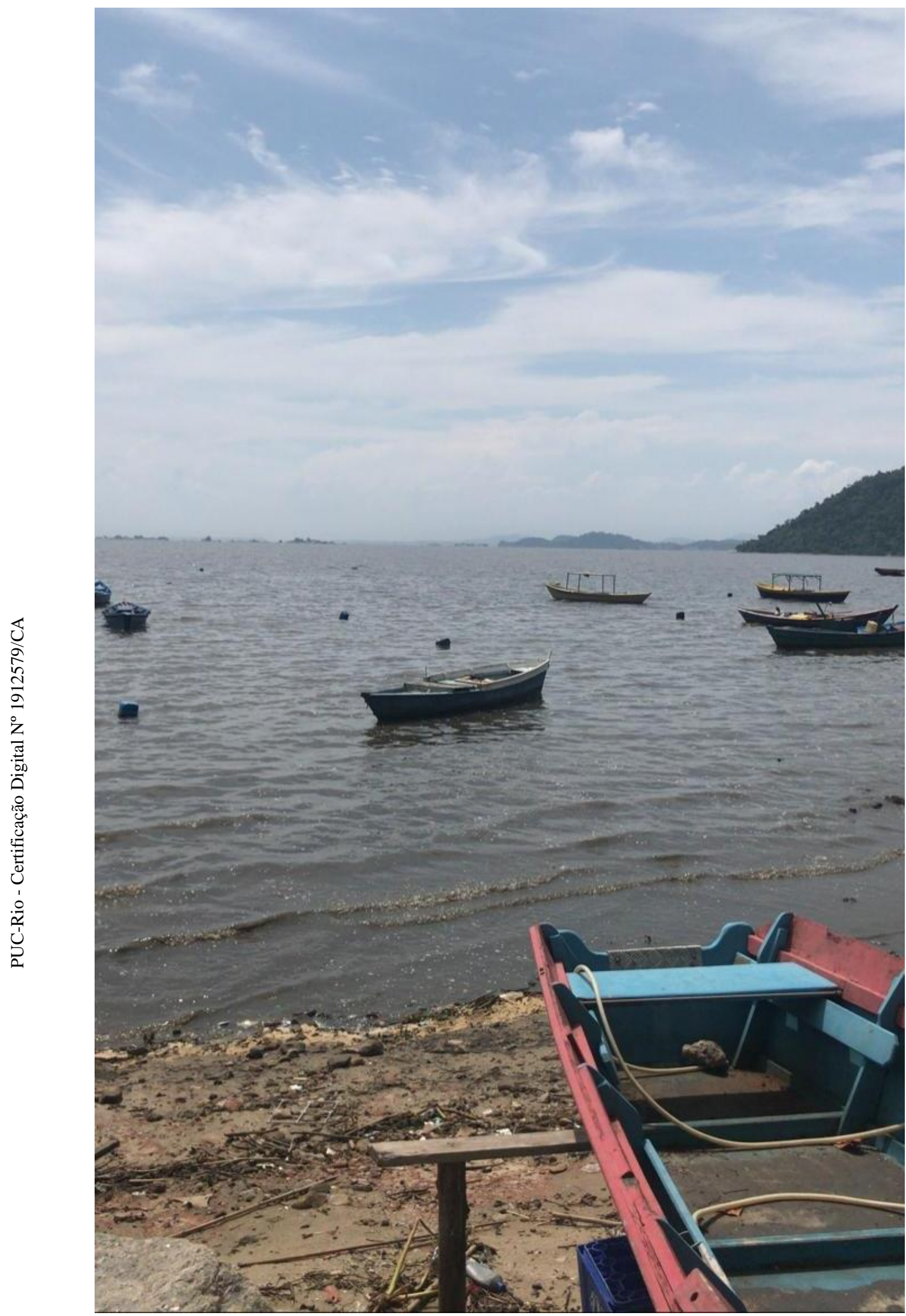

Figura 6 - Desafio do Lixo, edição fevereiro/2020.

Fonte: Registro da autora 


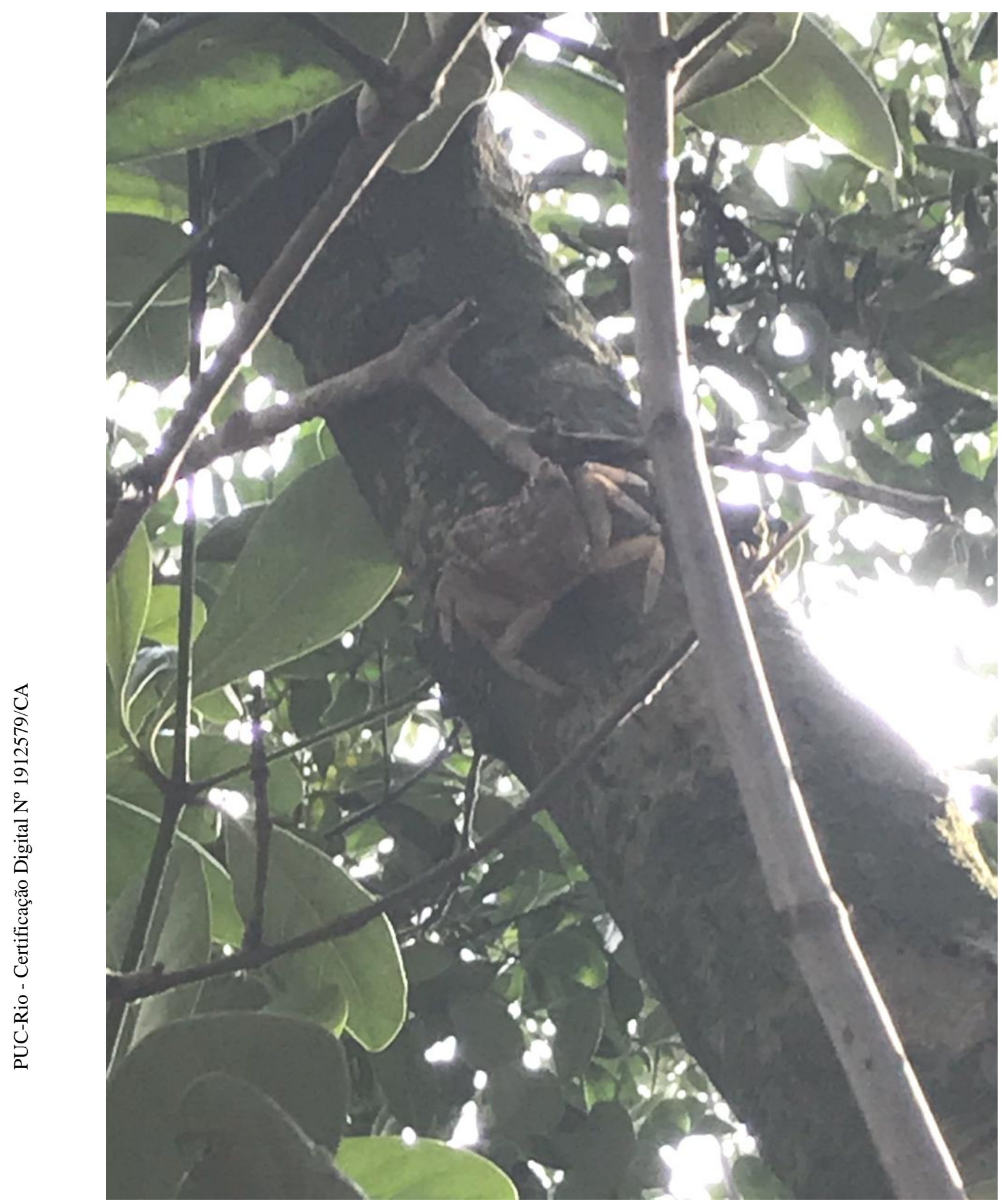

Figura 7 - Desafio do Lixo, edição fevereiro/2020.

Fonte: Registro da autora

Foi apurado que entre as articulações que fazem no Ressuscita São Gonçalo, os/as jovens atuam em diferentes movimentos e ações sociais na cidade além do Desafio do Lixo. Fato correlato às reflexões de Carrano (2006) sobre a diversidade de esferas de participação em que novos sentidos são experimentados nos territórios, (re)elaboram novas lógicas de ação política e coletiva. Desta 
aproximação formou-se uma rede de contatos e fui adicionada ao grupo de mensagens instantâneas do "Desafio do Lixo".

Conforme situado anteriormente, em março de 2020 o mundo foi surpreendido pela pandemia do novo coronavírus. Com o decreto de calamidade pública $^{25}$ autoridades recomendaram distanciamento físico e consequente suspensão de atividades em locais públicos que concentrassem coletivo de pessoas.

\subsubsection{Estreitando inquietudes}

Contudo, uma vez que a pesquisa fora apresentada e inserida no grupo de mensagens instantâneas do "Desafio do Lixo", o contato com os/as jovens foi feito e as observações adaptaram-se ao espaço web conforme possibilita a estratégia da ciber-etnografia (LACERDA; RAMALHO, 2020). Dentre as mensagens compartilhadas, está a da reunião para organização do que chamaram de "Laboratório de Análises - Covid-19". Associados à navegação nas redes de comunicação virtual, os/as jovens criaram momentos de integração entre realidades e reflexões sobre impactos deflagrados pela pandemia. Feixa e Weissböck (2019) destacam a instantaneidade e simultaneidade com que as juventudes redimensionam o tempo real e o tempo virtual permitindo conectividade não somente do ponto de vista tecnológico, mas de interesses, neste caso, políticos e sociais.

Em maio de 2020, o Laboratório de Análises das consequências do Covid-19 em São Gonçalo reuniu, de forma voluntária, a partir de postagem em mídias sociais, pessoas de diferentes áreas, idades e bairros. Entre os quase 30 (trinta) jovens presentes, destaco a presença da diversidade de gênero e grau de escolaridade, sobretudo saliento participação feminina e universitária.

Tendo presente os munícipes, por respectivos bairros e áreas de interesse, seja estudo ou trabalho, organizou-se grupos de trabalho (GTs), a saber: Educação, Economia, Geografia e urbanismo, História e Sociologia, Jurídico, Sustentabilidade, Saúde e Assistência Social. Por esta organização os GTs pesquisavam e analisavam dados oficiais em vias a torná-los acessíveis aos demais

\footnotetext{
25 RIO DE JANEIRO, Decreto ${ }^{\circ} 46.984$ de 20 de março de 2020. Reforça às informações sobre medidas de proteção e conforme o aumento do número de casos no Estado, decreta situação de calamidade pública em razão da Covid-19. Disponível em: https://pge.rj.gov.br/comum/code/MostrarArquivo.php?C=MTAyMzI\%2C Acesso em: 04 jun. 2020.
} 
munícipes uma vez que a contestação que apareceu com mais força era a necessidade de superar a ausência de clareza na comunicação Prefeituragonçalenses.

Incluída no processo, fui encaminhada ao GT de Educação para colaborar com levantamento de dados e informações sobre características e funcionamento das práticas escolares remotas desenvolvidas na cidade ${ }^{26}$. Estreitando inquietudes, debatemos e acompanhamos trâmites da entrega do kit merenda ${ }^{27}$ para estudantes da Rede Municipal de São Gonçalo e elaboramos material informativo para conscientização da necessidade de distanciamento físico.

Chamo atenção para a elaboração e compartilhamento de orientações para a realização das etapas de levantamento dos dados. Destaco itens 2 e 4 do documento (anexo 2) elaborado pelos participantes nos termos de "qual contexto do tema que você quer trabalhar com o recorte para São Gonçalo?" e "O que esses problemas afetam na vida da população de São Gonçalo?’. Sinais de orientações que combinam aspectos propositivos, conhecimentos e saberes territoriais ou ainda anúncio do que defende Santos (2019) para reconhecimento da co-presença de diferentes saberes nas práticas sociais: saber-com e não o saber-sobre.

Durante os meses de junho e agosto de 2020 o material apurado foi divulgado nas redes sociais do Ressuscita São Gonçalo. A figura 8 apresenta a postagem sobre o kit alimentação escolar distribuído pela Prefeitura de São Gonçalo.

\footnotetext{
26 Provocada pelas narrativas das professoras que contribuíram para este levantamento de informações propus reflexões sobre os desafios na docência em tempos pandêmicos no artigo "Luz, câmera, (desumaniz)ação: entre o pedagógico e a manutenção da vida, o que é ser professor/a em tempos de pandemia?". Disponível na Revista Interinstitucional Artes de Educar, volume 6, número especial II, p. 77-93 (jun-out 2020): “Educação e Democracia em Tempos de Pandemia".

27 A Prefeitura de São Gonçalo realizou entrega de kit merenda escolar para os 47 mil estudantes matriculados nas Rede Pública Municipal. A ação, direito dos estudantes, ocorreu em meio a controvérsias de superfaturamento e inadequação de produtos chamando atenção das juventudes. Para mais detalhes sugiro a reportagem feita pelo jornal local através do link https://www.osaogoncalo.com.br/servicos/82875/sg-distribuicao-de-kit-merendaescolar-comeca-segunda-feira-1.
} 

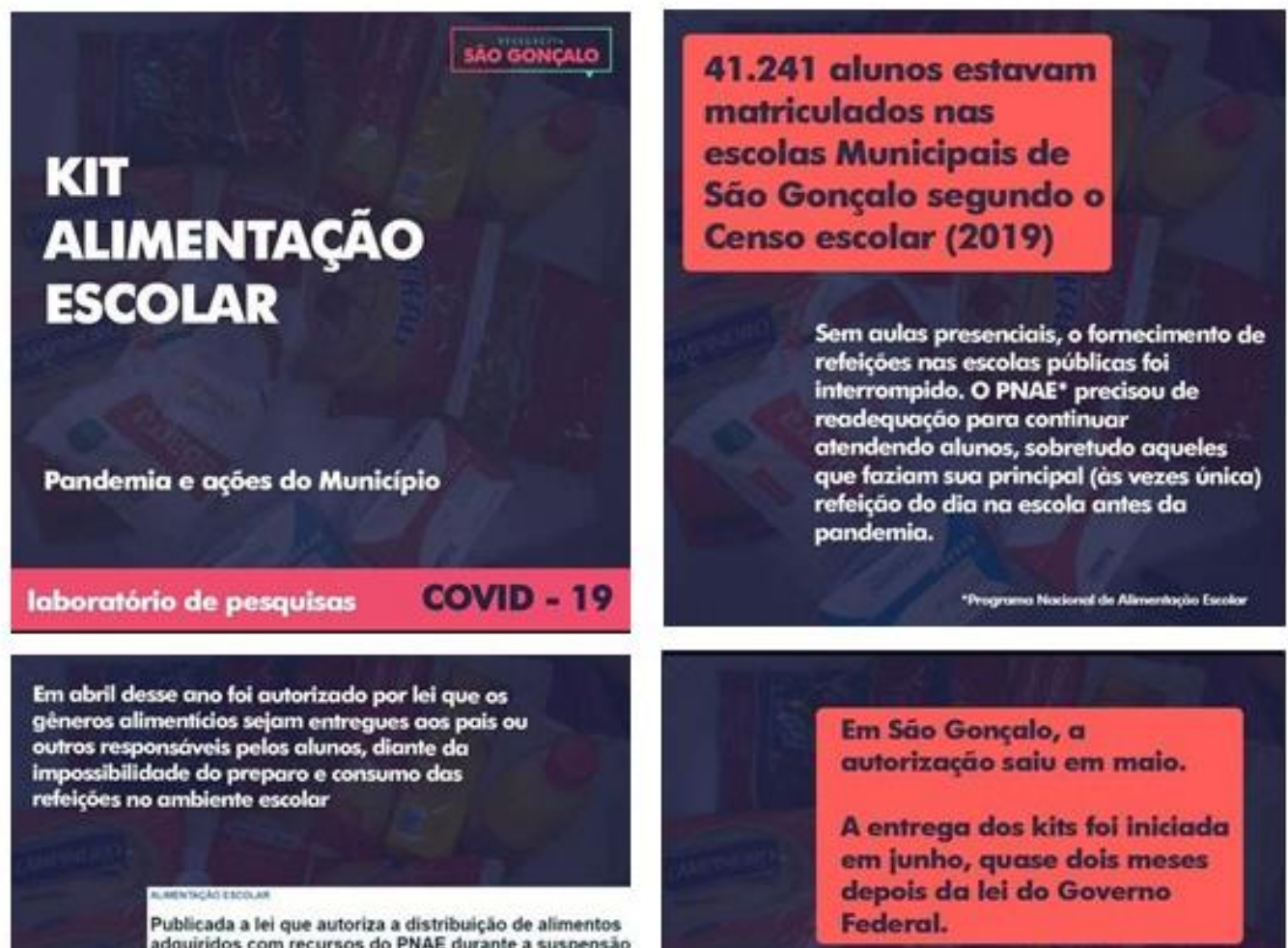

Publicada a lei que autoriza a distribuiçáo de alimentos adquiridos com recursos do PNAE durante a suspensibo das aulas na rede pública

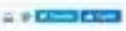

\section{Mas, e em Sáo Gonçalo?}

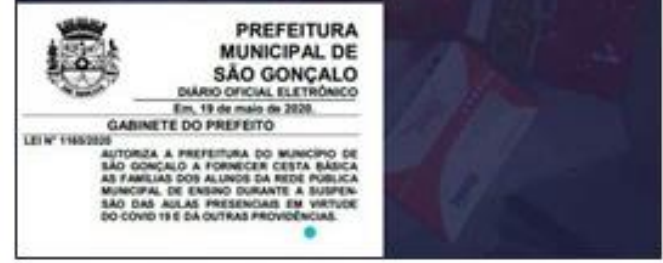

Foi contratada um empresa de

Minas Gerais para a aquisiçăo

de $\mathbf{4 7 . 4 9 8}$ kits por mês,

custando RS 34,80 cada uma.

Manifestaçōes contrárias a respeito do kit e dos locais de retirada foram feitas nas redes.

A conjuntura reforça ainda mais os impactos das desigualdades na vida dos gonçalenses.

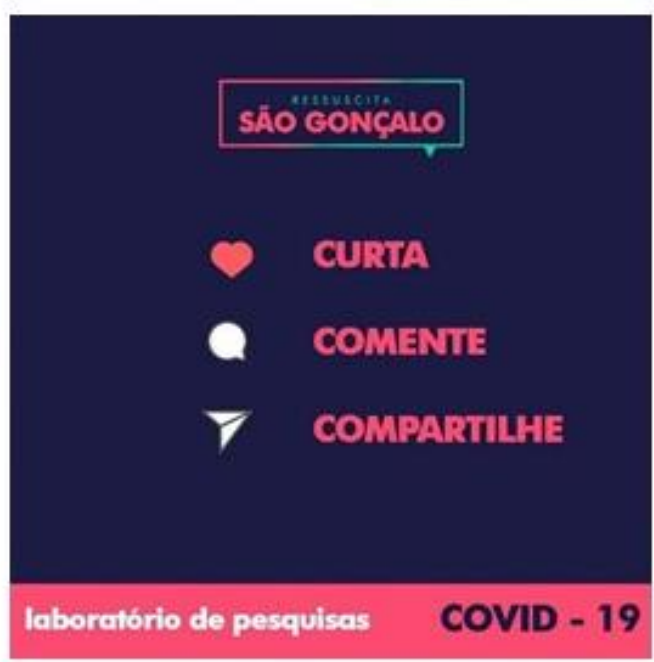

Figura 8 - Material de divulgação do Laboratório de Análise Covid-19, julho/2020.

Fonte: Projeto Ressuscita São Gonçalo

Em relação aos encontros virtuais sob o propósito do Laboratório de pesquisa e análises do Covid-19 em São Gonçalo, percebeu-se com o tempo baixa frequência. Apesar dos encontros se realizarem em datas espaçadas a presença nas 
reuniões chegou a 12 jovens. Ocorreu nesta época definição do plano de aulas emergenciais nas universidades públicas, pista que pode explicar este cenário. Cito ainda a discussão levantada por Carrano (2006) sobre possibilidades e interdições de participação social juvenil em que pese considerar facetas e fatores objetivos e subjetivos que favorecem e/ou dificultam seus engajamentos, como possível retorno às atividades acadêmicas, trabalho e permanência da situação de pandemia.

Durante o período de distanciamento físico mais rígido, os jovens participaram de outras atividades e redes de solidariedade na cidade. Dentre a variedade das quais recebi notícias estão ações de recolhimento de alimentos não perecíveis e material de higiene pessoal com posterior distribuição, especialmente nos bairros de maior vulnerabilidade da cidade ${ }^{28}$.

Outra ocasião de contestação e chamamento a manifestação ocorreu quando João Pedro, de 14 anos, foi morto, em sua casa, durante operação policial no Complexo do Salgueiro, bairro da cidade. ${ }^{29}$ A indignação é anterior ao anúncio da morte de mais um jovem negro e periférico, tendo início no compartilhamento de mensagens sobre o desaparecimento do adolescente e a forma com que a situação foi conduzida pela polícia. Família, amigos e munícipes buscaram notícias sobre o ocorrido por mais de $10 \mathrm{~h}$ até alcançarem informações de que João Pedro havia sido levado para base aérea na cidade do Rio de Janeiro em helicóptero oficial das polícias Civil e Federal envolvidas na ação. João Pedro foi encontrado morto no Instituto Médico Legal da cidade de São Gonçalo, no bairro de Tribobó. Revoltados e conectados ao imperativo "Vidas Negras Importam"30, ativistas e movimentos sociais organizaram uma manifestação em frente à prefeitura da cidade de São Gonçalo cobrando posicionamento das autoridades. Um dos jovens participantes desta pesquisa declarou "não dá mais pra aturar isso, vamos pra rua",

\footnotetext{
28 Para mais detalhes sugiro a reportagem "Conheça coletivos que ajudam comunidades em SG contra o coronavírus" do jornal local O São Gonçalo. A reportagem destaca atuação do coletivo "Por gentileza" que movimentou a "\#NaMinhaFavelaNão" em interação com outros movimentos e coletivos ativos em São Gonçalo. A reportagem está disponível em https://www.osaogoncalo.com.br/geral/80149/conheca-coletivos-que-ajudam-comunidades-emsg-contra-o-coronavirus. Acessado em 27 jul. 2020.

29 Para conhecer melhor o caso sugiro a reportagem https://www.brasildefatorj.com.br/2020/05/19/procura-se-joao-pedro-jovem-desaparecido-em-acaopolicial-no-rio-e-encontrado-morto . Acessado em 17 jan. 2021.

30 “Vidas Negras Importam” é tradução para "Black Lives Matter”. Black Lives Matter é um movimento global sinalizado nas redes sociais desde 2013. Criado para denunciar o racismo e a brutalidade policial contra pessoas negras, a expressão ganhou força em 2020 após assassinato de George Floyd, cidadão afro-americano asfixiado até a morte por policiais. Para mais informações sobre o caso que se tornou poderoso símbolo contra a matança sistêmica de pretos e pobres, sugiro as reportagens https://www.bbc.com/news/av/world-52967551 e https://g1.globo.com/mundo/noticia/2020/06/25/protestos-porgeorge-floyd-em-seis-areas-a-desigualdade-racial-para-negros-no-brasil-e-nos-eua.ghtml. Acessados 17 jan. 2021.
} 
sobre mais um caso de racismo e violência policial enquanto compartilhava o folder virtual e convidava para o evento.

\subsubsection{Desafio do encontro}

Em outubro de 2020, no cenário de retomada gradual ${ }^{31}$ das atividades, o grupo organizou uma nova edição do "Desafio do Lixo". Diante de protocolos e atenção as regras de distanciamento físico, combinou-se o encontro para a manhã de um domingo. Nesta edição do "Desafio do Lixo" foi oportunidade para encontrar, ver e ouvir para além das telas os/as jovens participantes.

Entre os receios que acompanham o processo de flexibilização das medidas sanitárias anteriormente fixadas, esta edição contou com a presença de 13 jovens. Entre eles/elas 7 eram participantes desta investigação. Assim, por volta das 10h caminhamos na Praia das Pedrinhas em direção a área do mangue.

Quanto a dinâmica dos diálogos observados, a pandemia e seus desdobramentos no mundo e na cidade eram os temas mais presentes. Outro elemento recorrente nas conversas foram as críticas aos planos de governo dos candidatos que disputavam as eleições municipais. Segundo uma das jovens, "é assustador a capacidade de fazer piada com o campo político e ainda colocar isso em propaganda". No entanto, somou-se aos diálogos expectativas para eleição de um dos jovens que participa do projeto Ressuscita São Gonçalo e concorria ao cargo de vereador.

Com base nas observações, pode-se dizer, que o fenômeno do engajamento das juventudes é diversificado e complexo, podendo ser apresentado por características que esboçam movimentos que vão além da crítica à realidade. Como argumenta Sposito (2000) é uma espécie de modalidade concreta em que, apesar de desconfianças com o sistema político representativo, não rejeitam as vias institucionais de representação democrática. Os resultados das observações ilustram juventudes em nova cultura de participação que tem início nas denúncias, mas privilegiam o agir de forma coletiva como identifica Gohn (2018). Ressalta-se que as observações foram importantes no momento de aproximação com os jovens.

31 As regras de restrição de circulação e distanciamento social foram flexibilizadas com base no Decreto Estadual 47.112/2020, compromissos com a retomada econômica e taxa de ocupação de leitos Covid-19 abaixo de 70\%, conforme decreto 142/2020 da Prefeitura Municipal de São Gonçalo. 
Além de vínculo e contextualização, as atividades observadas forneceram pistas a perseguir no desenvolvimento da pesquisa.

\subsection{No embalo, "Ressuscita São Gonçalo" e Casa Fluminense}

A partir das observações em campo, pode-se afirmar que as juventudes e suas novas formas de mobilização debatem desde temas da vida cotidiana à conteúdos estritamente políticos. Com isso quero apontar para o crescente reconhecimento de que processos cotidianos são em suma processos políticos. Dessa forma, ratifico a questão central desta investigação que é conhecer e compreender as motivações, saberes e fazeres que estariam gerando práticas de ativismo social nos jovens de origem periférica. O que estaria provocando a atenção dos jovens para estas questões sociais?

A exemplo disso, destaca-se em São Gonçalo, cidade da região metropolitana e $2^{\mathrm{a}}$ maior população residente do estado do Rio de Janeiro ${ }^{32}$, o projeto "Ressuscita São Gonçalo" que busca horizontalizar discussões sobre políticas públicas voltadas para a cidade. O Projeto efetivou-se em 2018 quando participou do edital "Fundo Casa Fluminense - Agenda Rio 2030"33, da ONG Casa Fluminense. O projeto tem por lema "Vamos juntos reconstruir nossa cidade". A escolha do nome se dá em alusão ao funk "Bonde da Zoeira" 34 , que em seu popular refrão "Ressuscita São Gonçalo, liberta DJ" localiza a cidade na cena musical dos anos 1990. Diga-se que os Mcs Claudinho e Buchecha, jovens e gonçalenses, têm outras rimas que enaltecem bairros e culturas da cidade e dessa forma serviram de inspiração para os jovens que lideram o "Ressuscita".

Os/as jovens que lideram o projeto Ressuscita São Gonçalo atuam na cidade sob propósito de pensar e fazer política de forma horizontal. O grupo trabalha para escutar a perspectiva da população gonçalense nas realidades e cotidianos de cada um dos 91 bairros que compõem o município.

\footnotetext{
32 De acordo com dados do IBGE. https://cidades.ibge.gov.br/brasil/ri/sao-goncalo/pesquisa/23/25207?tipo=ranking. Acessado em 18 jan. 2020. 33 “Agenda Rio 2030 - Formação, mobilização e monitoramento" é um edital da Casa Fluminense com chamada para projetos de incidência no território da região metropolitana. Em 2019 recebeu 209 inscrições de projetos com atuação em 17 municípios da região metropolitana. Entre os 15 projetos contemplados com aporte de 4 mil reais, 3 são projetos de jovens gonçalenses, entre eles o Ressuscita São Gonçalo.

34 Letra do Funk disponível em https://www.letras.mus.br/claudinho-e-buchecha/bonde-da-zoeira/. Acessado em 20 fev. 2020.
} 
$\mathrm{O}$ referido grupo de jovens criou um questionário online que buscou em consulta pública mapear respostas para “qual cidade nós queremos?”. O questionário foi amplamente divulgado e recebeu respostas entre os meses de agosto a outubro de 2019. Com publicações nas redes sociais virtuais e intervenções presenciais em praças da cidade, $415^{35}$ formulários foram preenchidos. Dentre os resultados obtidos na pesquisa do projeto, captou-se bairro, renda, escolaridade e idade dos munícipes. Nesta atividade os jovens identificaram, conforme figuras $8 \mathrm{e}$ 9, que a violência na cidade, é, de acordo com os gonçalenses respondentes, o primeiro e o segundo problema mais grave da cidade, seguido de organização da cidade (pavimentação e iluminação pública), educação e cultura, saneamento básico (água, lixo e esgoto), saúde e transporte.

O questionário elaborado pelo projeto contou com duas questões para preenchimento por extenso, sendo elas "Quais são as principais potencialidades de São Gonçalo?" e "Qual a São Gonçalo que você sonha em 10 anos?”. Assim, reiterando o compromisso de ouvir, diagnosticar, articular e estruturar objetivos e metas realizáveis para a cidade, o grupo de jovens elaborou um documento que foi encaminhando aos candidatos a cargos políticos dispostos nas eleições municipais de 2020.

As lideranças do projeto pretendem firmar compromisso público de uma agenda possível para os próximos 10 anos da cidade. O documento teve seu lançamento no dia 24 de outubro de 2020 em live transmitida ao vivo nas plataformas virtuais da Casa Fluminense. No documento intitulado "Agenda São Gonçalo 2030"36 constam gráficos, análises e narrativas dos munícipes sobre o território gonçalense. Nas figuras 9 e 10 algumas das respostas que os jovens incluem na “Agenda São Gonçalo 2030”.

\footnotetext{
35 Número justificado como representativo considerando o tamanho estimado da cidade e adaptação de cálculos de Willian Gemmell Cochran em Sampling techiniques-3 (1997). Segundo o IBGE, São Gonçalo tem população de 1.84 .839 pessoas. Para alcançar representatividade na amostra o grupo explica que o cálculo aponta para a necessidade de 358 respostas.

36 A “Agenda locail 2030" é resultado do trabalho e análise de dados territoriais de projetos realizados em cidades da Região Metropolitana. A agenda local 2030 de Queimados, Japeri, Santa Cruz e São Gonçalo teve seu lançamento em live por diferentes plataformas virtuais, entre elas Youtube, Instagran e Facebook. Entretanto, a videogravação do evento encontra-se disponível em https://www.facebook.com/ressuscitasaogoncalo2019/videos/1617090661796280/ na página do Facebook do Projeto Ressuscita São Gonçalo. Acessado em 06 jan. 21.
} 
- PC06: Qual dos temas abaixo representa o problema mais grave no seu dia a dia em São Gonçalo?

Consulta pública Ressuscita Săo Gonçalo: PC06

234

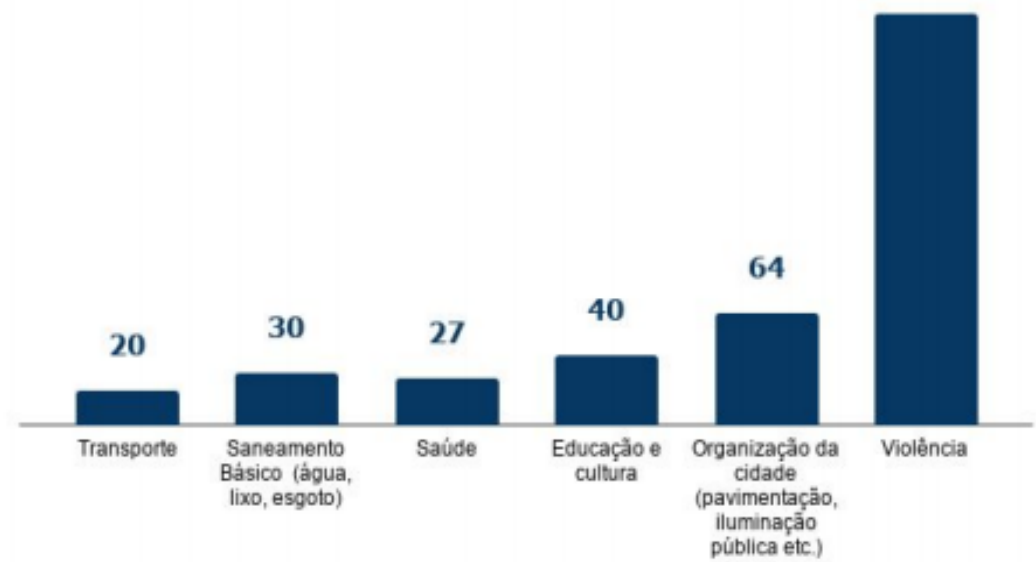

- PC13: Qual dos temas abaixo representa o segundo problema mais grave no seu dia a dia em São Gonçalo? Exclua o escolhido na opção anterior.

Consulta pública Ressuscita São Gonçalo: PC13

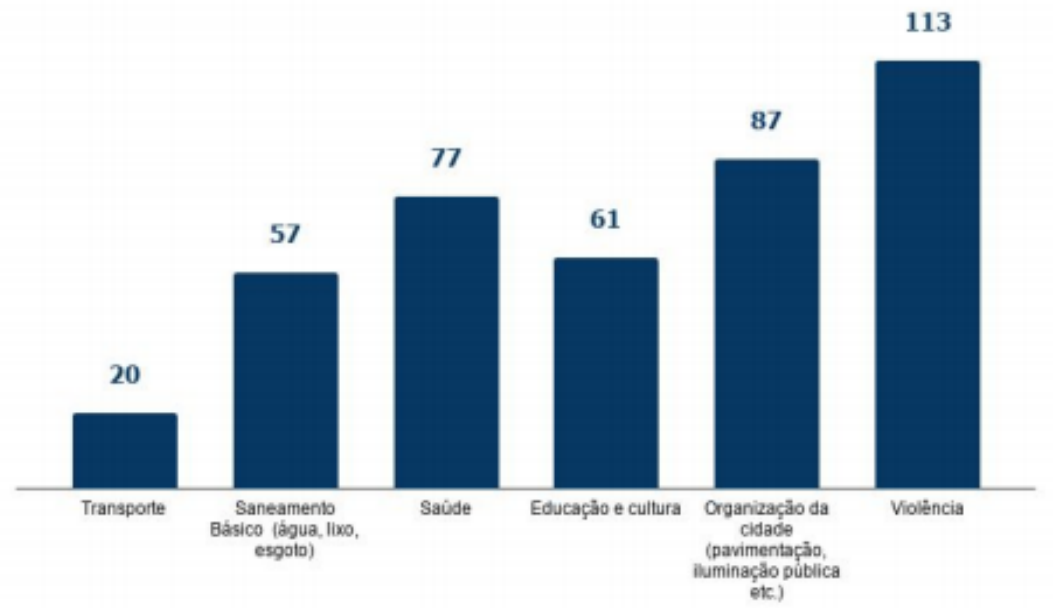

Figura 9 - Dados a partir de consulta pública - Ressuscita São Gonçalo/2019. Fonte: Projeto Ressuscita São Gonçalo 
- PC20: Quais são as principais potencialidades de São Gonçalo?

Algumas respostas foram selecionadas entre as enviadas pelos respondentes, sendo mantidas na íntegra:

"Muitos jovens ativos e com vontade de mudança" Nova Cidade - 06/08/2019 às $19: 32: 18 \mathrm{~h}$

"Uma cidade tão grande que gera vários artistas e cabeças pensantes pode crescer e se tornar mais sustentável, responsável e respeitavel. Adoro minha cidade. Cresci aqui e me dói ver tanta violência e descaso. Muda sg! Vamos nos unir e melhorar nosso país metropolitano. " Centro (Rodo de SG) - 06/08/2019 às 20:57:42h

"Creio que São Gonçalo possui inúmeros potenciais, a exemplo de um grande potencial intelectual das crianças e jovens, entretanto o direcionamento escolar ainda não alcança uma grande maioria. Além disso, possui um grande potencial empresarial, visto que a cidade possui mais de 1 milhão de habitantes e atrair investimentos não seria impossível, mas são necessários pontos atrativos para a cidade, como a diminuição da violência e corrupção política já estabelecida há anos." Centro (Rodo de SG) - 06/08/2019 às 21:15:46h

"Expansão territorial para o desenvolvimento de atividades industriais, principalmente nos entornos da BR-101 com condições favoráveis à implementação do serviço de barcas, junto à continuidade da antiga linha férrea para o trânsito de pessoas e mercadorias. " Colubandê - 07/08/2019 às $00: 06: 35 h$

"No momento não vejo nada de positivo, se pessoas com medo " Gradim - 07/08/2019 ás 06:54:40h

"Comércio. Turismo (praias e mangues - podem ser recuperados, Cavernas, Sítios, Morro do Gaia, Casarões das Fazendas); Comércio, Ciclismo. Etc" Alcântara $07 / 08 / 2019$ às $15: 03: 42 \mathrm{~h}$

Figura 10 - Dados a partir de consulta pública - Ressuscita São Gonçalo/2019.

Fonte: Projeto Ressuscita São Gonçalo

No que diz respeito aos jovens e associativismos que realizam, percebeu-se conexão com outros projetos sociais, além do Desafio do Lixo. Entre as conexões estão o grupo VP Gente (que mapeia ações sociais da cidade e faz ponte com possíveis voluntários), Grupos de Jovens em instituições religiosas (Católica, Espírita e Pentecostal), a ONG Mulheres do Salgueiro (que atua na qualificação de mulheres em situação econômica vulnerável), projeto Nós por nós (Pré vestibular 
comunitário), projeto Por Gentileza (capta e realiza distribuição de doações de cesta básicas e material escolar), Agencia Papa Goiaba (promove agenda cultural gonçalense), Projeto Coletaí (capta parcerias para criação de ecopontos para descarte de resíduos em pontos estratégicos da cidade), Grupo de Leitura de escritores vivos, Diretórios e centros acadêmicos (UERJ-FFP e PUC-Rio), Centro de valorização da vida - CVV ( realiza apoio emocional e prevenção ao suicídio), Projeto Manivela (atua de forma multisetorial no desenho de estratégias e acompanhamento de associações de moradores de favelas e subúrbios cariocas), Rio Criativo (movimenta iniciativas na área da Economia criativa no Estado do Rio de Janeiro), ONU Habitat (Programa das Nações Unidas dedicada a promoção de cidades mais sociais e ambientalmente mais sustentáveis) e ONG Casa Fluminense (atua com atividades para construção de políticas públicas para a região metropolitana do Estado do Rio de Janeiro).

Os ativismos realizados pelas juventudes que participam desta pesquisa evidenciam propósitos de sujeitos coletivos para transformação social e valorização do território gonçalense. Os/as jovens sugerem ações nas fissuras sociais locais comunicando horizontes e estratégias para superação de descasos que subalternizam os territórios periféricos. Algo que na perspectiva do referencial teórico abordado nesta dissertação, aponta para "brechas decoloniais" onde alianças se constroem em resistência, transgressão e insurgências para (re) criar e (re)construir o vívido (WALSH, 2016).

Notou-se ainda que a conexão com a ONG Casa Fluminense repercute além do apoio financeiro alcançado no edital Agenda Rio 2030. Os jovens relataram participação em diferentes atividades promovidas pela instituição. Para melhor compreender esta conexão busquei contato com a referida instituição. Em resposta fui encaminhada a Assessora de Mobilização da Casa Fluminense, que coordena os projetos do Curso de Políticas Públicas e o Fundo Casa Fluminense. Após esclarecimento dos termos de participação voluntária, combinamos data e horário para encontro virtual e realização da entrevista.

Fundada em 2013, a Casa Fluminense é uma ONG que se dispõe a defesa de uma agenda pública voltada ao território e população periférica da região metropolitana do Estado do Rio de Janeiro. A ONG apresenta-se como espaço para a construção coletiva de políticas para a promoção de igualdade e o aprofundamento democrático no Rio de Janeiro. Em sua organização conta com pesquisadores/as 
das questões urbanas em diversas áreas. Geógrafos/as, Antropólogos/as, Urbanistas e Cientistas Sociais com experiências em agências do poder público e/ou atuação em lideranças comunitárias trabalham na instituição. Segundo Valéria, a ONG

trabalha com o recorte da região metropolitana do Rio não é à toa, é por a gente entender que existe pouquíssima articulação entre as decisões a nível municipal dos diferentes municípios, apesar dos problemas que a população enfrenta serem absolutamente integrados. Não tem como resolver, por exemplo, os desafios no transporte público, se esse transporte não for pensado a nível da região metropolitana. A gente não consegue resolver as questões de saneamento se a gente focar só no nível municipal. E é isso. A vida da metrópole ela é completamente integrada né, os moradores da Baixada Fluminense, de São Gonçalo, de Niterói, do oeste metropolitano...boa parte desses trabalhadores eles têm que acessar oportunidades de estudo, de emprego, de acesso à cultura, a lazer, tudo na capital. E a gente nasce com essa proposta de que é preciso pensar o Rio para além do cartão postal, para além da região do Centro, da Zona Sul e da Barra da Tijuca [...] e a gente nasce com a missão de dizer que essa cidade, ela não é esse cartão postal. Ela é também Japeri, ela e também São Gonçalo, ela é também Nova Iguaçu.

A partir do relato de Valéria é possível perceber que a ONG se coloca em posição de denúncia e anúncio a respeito de temas como gestão e políticas públicas para as cidades da região metropolitana. Em nosso diálogo, a entrevistada demonstrou especial atenção à necessidade de representação popular e periférica nos espaços de decisão legislativa. Segundo a entrevistada, a instituição na qual trabalha reconhece que

a maioria das vezes, esses espaços (de decisão legislativa) são restritos a especialistas que estão nas Universidades discutindo isso e a tomadores de decisão que são, em sua maioria, homens brancos de outra geração, não são jovens e são ricos. Então a gente acha que é impossível produzir soluções só com esses atores [...] essas decisões elas têm que ter participação social, tem que ter... Tem que ouvir os movimentos sociais, tem que ouvir as organizações da sociedade civil, tem que ouvir as organizações comunitárias, tem que ouvir a população de uma maneira mais ampla.

[...] são as pessoas que vivem esses desafios e não só estão lidando com números, mas estão experimentando isso na sua vida diária, e mais do que isso, já estão formulando uma série de estratégias para lidar com uma infraestrutura urbana que é muito falha, um transporte que é massacrante, que é super caro, uma dificuldade de acessar oportunidades que é impeditiva muitas vezes desses jovens tentarem uma mobilidade social, então essa galera que está vivendo na pele, tem condições de formular elas.

O relato indica que a Casa Fluminense busca dialogar "com quem já está fazendo muito nos seus próprios territórios, que já está atuando de uma maneira muito integrada, muito sofisticada, e atuando em rede [...] É isso. Basicamente fortalecer o que eles já estão fazendo”. A entrevistada expressa ainda que o interesse da ONG está em 
dialogar com profissionais, mas também com jovens que estão dispostos a ingressarem nessa... Tanto nesses campos profissionais, mas também jovens que estão dispostos a mobilizar pessoas, a discutir isso a nível local, a trazer essa discussão para o nível do bairro, da favela, e de fato brigar por uma maior representatividade, mas não só representatividade, uma maior participação social de uma maneira mais ampla, porque a partir do que a gente acredita é isso, a gente acha que quem enfrenta os maiores desafios são também as pessoas que têm a maior condição de formular soluções eficazes [...] por exemplo, candidatos e vereadores e deputados que sejam negros, que sejam mulheres, que sejam de origem popular, mas não só isso. Não só pessoas com mandatos. Mas lideranças comunitárias novas. Lideranças comunitárias orgânicas, e que consigam fazer parte dessas soluções. Então a gente na verdade tem esse trabalho.

Os argumentos apresentados na fala de Valéria agregam alguns elementos que se relacionam com a perspectiva da interculturalidade crítica defendida por Walsh (2009a, 2009b), Santos (2010) e Candau (2016a). Em virtude do que foi mencionado a ONG aposta em práticas de valorização e diálogo entre diferentes saberes presentes na sociedade, sejam eles saberes científicos ou saberes sociais de "quem sofre as consequências diárias das decisões boas ou ruins que essa galera toma, e é quem também tem condições de saber o que funciona e o que não funciona. Bolar essas soluções”.

No que diz respeito a forma de trabalho da Casa Fluminense, Valéria explicita que a ONG está organizada em três eixos prioritários: informação, mobilização e incidência. Segundo a entrevistada, o eixo de informação trabalha na sistematização de dados oficiais. Uma vez sistematizados em infográficos, mapas ou cards revelam realidades sobre mobilidade urbana, saneamento básico, Baia de Guanabara, educação, saúde, cultura. Neste mesmo eixo a ONG promove a formulação de agendas locais em parceria com lideranças e projetos situados nos territórios da região metropolitana, como por exemplo a Agenda 2030 São Gonçalo já mencionada neste trabalho.

a gente envia esse documento para a galera comentar, enfim, para de fato aquilo representar os anseios dessa rede metropolitana, ser uma construção participativa de fato. Se é isso que a gente está cobrando do poder público, a gente não pode simplesmente sentar na nossa sala e querer traçar todas as soluções. Até porque isso não é possível assim, eu acredito muito nisso, que não é possível produção de conhecimento sem diversidade, sabe?! Então mais do que a gente... É óbvio que isso é verdade, a gente tem um papel fundamental em qualquer coisa que a gente faça de contribuir para a redução de desigualdades e de superação de dívidas históricas que a gente tem com a população negra, por exemplo. Mas isso é só uma parte da importância da diversidade. A outra parte é: a gente simplesmente não vai formular um conhecimento que reflita a complexidade da região metropolitana se a gente não tiver os jovens negros de favela falando sobre isso. É um conhecimento muito limitado se são só pessoas brancas escrevendo. 
Relativo à "Agenda local 2030" de São Gonçalo, Valéria expressa um comentário específico sobre os participantes desta pesquisa

eles (os jovens do projeto Ressuscita São Gonçalo) se propuseram a fazer muitas coisas e a gente ficou assim: "cara, é muita coisa para pouco tempo. Mas vamos lá. Se vocês conseguirem dar o start no processo, já é muito maneiro". Porque essa coisa da formulação da agenda local ela é um processo muito maneiro, que permite muita coisa. Permite fazer rede, permite... Principalmente permite para os grupos terem um foco no monitoramento. O que eu vou cobrar da prefeitura? Ah, isso aqui que eu já conversei com uma galera, e aí por isso a gente gosta muito, assim, do projeto que rolou em São Gonçalo.

No que se refere aos jovens gonçalenses, o próximo trecho da entrevista ilustra fatos já referenciados nesta investigação sobre a diversificação de iniciativas e frentes de trabalho com e para o município.

ao longo desse tempo a gente conseguiu encontrar grupos com atuações muito inspiradoras em São Gonçalo [...] "Nós por nós", candidatura do Rodrigo, que eleito ou não conta muito, o "Cozinha sem medo" do núcleo do MTST de São Gonçalo e os núcleos comunitários para pensar essas políticas urbanas [...] Cara! São pessoas sensacionais, são jovens sensacionais que já tem uma visão de mundo e uma construção ali sobre o quê que São Gonçalo precisa, que é isso, é muito sofisticada já, porque tem a ver com a experiência deles, de experienciar todos os desafios e com o truco que eles... Toda a experiência acadêmica e profissional que esses jovens tem também, porque é isso, eles tem muito. Eu acho que isso a gente espera e torce e o nosso objetivo é esse mesmo, que esses grupos, enfim, aconteçam desdobramentos daqui a cinco anos, dez anos, sei lá, que de repente a gente não vai nem conseguir acompanhar, mas que isso vá embora, assim, literalmente.

Vê-se por aí, pela maneira com que apresentam seus engajamentos, com e a partir das experiências que tem na cidade, a emergente dimensão do cotidiano nas modalidades de ação. Situação que reflete o anunciado por Sposito, Almeida e Carrochano (2020) sobre os recentes ativismos e ocupações que "apesar do uso intensivo de redes on-line, existem e se fortalecem nas redes off-line, nas ruas, mas também no estar juntos diário e nos pequenos coletivos (p. 6).

A respeito do eixo de mobilização, os aspectos apontados por Valéria denotam que o eixo informação e o eixo mobilização trabalham lado a lado para sensibilizar os sujeitos à participação e engajamentos em seus territórios. Dentre os materiais produzidos pela ONG a entrevistada destaca 
Tem o Mapa da Desigualdade ${ }^{37}$, infográficos sobre debates quentes na grande mídia como por exemplo o adia Enem e o covid-19 [...] Mas que também tenha uma referência de quem está fazendo esse debate... a imprensa, pesquisadores, grupos comunitários podem ir lá e pegar não só o card, mas também uma coisa mais extensa né sobre o quê que aquele dado quer dizer.

A entrevistada adiciona

Aí tem isso e tem outras duas dimensões no eixo de mobilização, que é a formação, os processos formativos que a gente faz na casa [...] O principal né, é o curso de políticas públicas que é um curso que está na quinta edição e é esse curso voltado para lideranças comunitárias, ativistas, militantes e jovens engajados nas periferias metropolitanas em temas que se relacionem com acesso à cultura, monitoramento de políticas, enfim, desenvolvimento comunitário. A gente não tem uma limitação de temática, todo mundo que está afim de colar junto para fazer uma transformação local. É isso. E aí esse curso ele é pensado para que a gente também promova esse espaço de conexão para os alunos irem se conhecendo e pensando coisas juntos e enfim, mas também é um curso que tem uma marca de diversidade territorial. [...] O curso hoje, ele tem uma procura muito grande. Nessa última edição a gente teve acho que mais de oitocentas inscrições, e a gente ofereceu trinta e cinco vagas só. Ainda tem alimentação dos alunos e a passagem dos alunos. [...] Essa turma agora tem alunos de treze municípios, e isso faz com que todo ano a gente conheça pessoas novas daqueles municípios e pessoas novas engajadas. [...] essa turma ela é de oitenta por cento de pretos e pardos, mas com o foco também de que a maioria seja preta, e também com o foco de uma diversidade de gênero. E isso tem a ver com uma maioria de mulheres, mas também com pessoas trans e também com uma diversidade de orientação sexual. Não é fácil. Tem grupos que a gente quer atingir e que a gente tem que suar mesmo para realmente trazer essa galera para a turma. Porque às vezes a gente não tem o alcance, enfim, as pessoas às vezes não ficam sabendo do curso, então a gente tem que fazer uma busca ativa desses públicos.

O intercâmbio entre os eixos de trabalho da Casa Fluminense evidencia uma proposta de atuação para visibilização do cotidiano dos territórios. De acordo com o trecho destacado percebe-se que a instituição desempenha metodologias de informação e mobilização. Além de estabelecer uma crítica às dominações sociais de classe, raça e gênero, o trecho expresso por Valéria apresenta que a agenda da referida instituição busca diálogos e conexões com e a partir das resistências e histórias de luta dos sujeitos jovens engajados localmente. Práticas que apresentam afinidade com o pedagógico e decolonial proposto por Walsh (2009a) e Candau

\footnotetext{
37 O Mapa da Desigualdade é um material produzido em pesquisa realizada pela Casa Fluminense. O material 40 principais indicadores, encontrados em 26 bases de dados, que retratam de forma acessível a população os desafios socioeconômicos da Região Metropolitana. O estudo encaixa diferentes eixos temáticos como: habitação, emprego, transporte, segurança, saneamento, saúde, educação, cultura, assistência social e gestão pública. Em 2020 foi lançada $2^{\mathrm{a}}$ versão do mapa. O mesmo encontra-se disponível em https://casafluminense.org.br/nova-edicao-do-mapa-da-desigualdade-ja-esta-disponivel-paradownload-gratuitol. Acessado em 05 jan. 2021.
} 
(2008) enquanto aposta e prática social que parte da afirmação e valorização das histórias dos sujeitos socioculturais. Nas palavras de Walsh (2009a)

la pedagogía se entiende más allá del sistema educativo, de la enseñanza y transmisión de saber, y como proceso y práctica sociopolítico, productivo y transformativo asentado en las realidades, subjetividades, historias y luchas de la gente, vividas en un mundo regido por la estructuración colonial (WALSH, 2009a, p. 13).

Ainda sobre o eixo de mobilização, além do curso de Políticas Públicas oferecido pela $\mathrm{ONG}$, Valéria destaca os fóruns locais ${ }^{38}$ realizados em parceria com pesquisadores e universidades. Nas palavras da entrevistada

(o fórum local) acaba sendo um espaço importante assim, tanto de a gente conhecer as pessoas, mas especialmente que as pessoas se conheçam entre si. Então o fórum é em São Gonçalo, mas a gente leva gente de Japeri, leva gente de Santa Cruz, que a gente coloca transporte para as pessoas que quiserem fazer inscrição, ir, tem esse transporte. Então vai gente de Caxias, da zona oeste, da zona norte, de vários lugares. Por quê? Porque é essa rede metropolitana que a gente está tentando formar. Então é isso. Tem os ciclistas de São Gonçalo, mas tem a galera da bike de Queimados também, que é o 'Pedala Queimados'. E esse pessoal precisa conversar. Quanto mais eles conseguirem trocar e bolar coisas juntas, e trocar experiências e se verem um na questão do outro, mais a gente consegue fortalecer os dois, e fortalecer essa pauta a nível metropolitano.

Segundo a entrevistada, o eixo de mobilização centra suas ações em "tentar tornar mais acessível um debate que é muito elitizado, que é muito restrito a gestores públicos, a iniciativa privada, a homens brancos velhos, conservadores e ricos”. Como já mencionado, a entrevistada é Assessora do eixo de mobilização e coordena os projetos do Curso de Políticas Públicas e o Fundo Casa Fluminense. Quando questionada sobre o desenvolvimento de seu trabalho a entrevistada reitera ser fundamental promover interlocução entre os sujeitos e engajamentos locais com os engajamentos em diferentes territórios.

A gente vai tentar fazer com que esses assuntos estejam acessíveis para todo mundo, acessiveis para o território, acessiveis para quem é do Jardim Catarina $(S G)$, para quem é do Jardim Gramacho (Duque de Caxias), para quem é da Vila Kennedy (RJ), para que essas pessoas sejam também multiplicadores do que a gente está falando.

Ao longo da entrevista verificou-se que no eixo de mobilização está também o Fundo Casa Fluminense. O referido programa foi criado pela instituição em 2015,

38 Em junho de 2018 aconteceu na Faculdade de Formação de Professores da UERJ, na cidade de São Gonçalo, a $11^{a}$ edição do Fórum Rio. Cerca de 300 líderes comunitários debateram temas sobre as particularidades e semelhanças da região metropolitana com e a partir de seus 22 municípios. Dentre os temas estão Emprego e Renda, Saneamento Básico, Segurança Pública e Direito a vida. Informação disponível em https://casafluminense.org.br/rio-porinteiro-mais-participacao-social-eleicoes2018/. Acessado em 05 jan 2021. 
atua com apoio financeiro e estratégico para fortalecimento das iniciativas e organizações comunitárias dos territórios da região metropolitana. Os editais do Fundo Casa Fluminense são lançados anualmente. Sobre o processo de seleção dos projetos, Valéria expressa que a instituição prioriza projetos

que venham das periferias metropolitanas, liderados por jovens, por pessoas negras, por mulheres e que tenham alinhamento com a Agenda Rio. E ai alinhamento com a Agenda Rio, o que a gente está querendo dizer? Esses projetos eles têm alinhamento com os valores da instituição, com os valores e com a missão de promover a redução de desigualdades de oportunidades. [...] projetos voltados para o meio ambiente, desde agricultura urbana até cinema de periferia

Nessas condições, a entrevistada reflete sobre o projeto "Apadrinhe um Sorriso $^{39 ", ~ c o m ~ a t u a c ̧ a ̃ o ~ n a ~ c i d a d e ~ d e ~ D u q u e ~ d e ~ C a x i a s ~}$

por exemplo, de educação e de cultura que tem, sei lá, no Parque das Missões aqui em Caxias, o 'apadrinhe um sorriso' que é voltado para crianças, que é isso, é ampliar o acesso à cultura, à arte para essas crianças e um trabalho muito forte de autoestima da população negra. E fundamental. A gente tem que estar em contato, a gente tem que fortalecer, a gente quer apoiar. Então essa diversidade assim que a gente busca.

Tendo em vista as especificidades de cada projeto aplicado ao edital promovido pela ONG, Valéria reflete sobre o projeto "Ressuscita São Gonçalo", contemplado no edital lançado em 2019:

(O Ressuscita São Gonçalo) é legal porque o Rafael passou pela casa, então a gente vê no projeto que ele trouxe, que ele trouxe muito uma visão, assim, Casa Fluminense que ele trouxe do curso para o projeto, mas também com uma pegada muito específica de São Gonçalo né, que é... Os próprios eixos que eles escolhem tratar, foi uma construção coletiva, eles não tiraram da Agenda Rio, o que é fundamental né, não é para fazer uma Agenda Rio de São Gonçalo.

De acordo com os trechos, a centralidade do trabalho do eixo de incidência é amplificar vozes que ecoem pressões políticas junto ao poder público. A entrevistada declara que a ONG aposta nas lideranças comunitárias informadas e mobilizadas para a transformação de seus territórios. Como principal estratégia de incidência, Valéria destaca o diálogo e a cooperação em interlocução com Ministério e Defensoria Pública. Porém, a entrevistada relata experiências que se apresentam como dificuldades uma vez que "a gente não tem governos muito

\footnotetext{
39 "Apadrinhe um Sorriso" é uma ONG que atua na comunidade do Parque das Missões com educação no contra turno para crianças e jovens de famílias socialmente instáveis. Investe em formação cognitiva, cultural e artista integrando a família, comunidade e os padrinhos. Informação disponível em http://apadrinheumsorriso.com.br/. Acessado em 05 jan. 2021.
} 
abertos à participação popular". Sobre o trabalho desenvolvido no eixo de incidência a entrevistada expressa que

tem uma incidência que a gente chama de incidência no debate eleitoral. Que é a gente pegar a Agenda Rio e divulgar essa Agenda Rio e convidar os candidatos a subscreverem a Agenda Rio. É como se fosse... Muitos movimentos fazem, por exemplo, cartas. Aí convidam candidaturas para assinarem. A gente tem a Agenda Rio, que a gente quer que as candidaturas assumam, incorporem nos planos de governo. Então tanto as candidaturas quanto os eleitos a gente tenta fazer essa incidência com a Agenda Rio. Eé isso.

Através das representações de Valéria a respeito das ações da ONG, observou-se que a lógica hegemônica do espaço público de criação de políticas públicas para as cidades é fortemente questionada pela instituição. Dessa forma é possível afirmar que o objetivo da instituição é fortalecer lutas e resistências que já existem no interior das periferias. Ao longo da entrevista evidenciou-se que a referida instituição quer pensar “com” e praticar "a partir" dos territórios periféricos da região metropolitana.

De acordo com o depoimento da entrevistada as formas de trabalho da ONG parecem configurar-se em direção a (re)construção dos territórios fragmentados pela desigualdade social. Ações e práticas repercutidas em informação e denúncia das desigualdades que configuram a sociedade moderna/colonial. Como diria Santos (2007), territórios fragmentados pela linha abissal que, por sua vez, sustenta a injustiça social global e a injustiça cognitiva global. Paralelamente à atuação da ONG junto às lideranças comunitárias, especialmente as lideranças juvenis, parecem mobilizar e anunciar sujeitos, epistemologias, práticas pedagógicas e políticas em leitura positiva sobre as diferenças culturais e sociais presentes nos territórios periféricos.

Práticas pedagógicas que parecem se colocar a partir das lideranças juvenis engajadas em seus territórios. De acordo com os relatos de Valéria, a ONG aposta na afirmação dos "jovens que sejam negros, que sejam mulheres, que sejam de origem popular”, ou seja, nos sujeitos do sul global cuja existência histórica e politica é silenciada.

Evidenciou-se ao longo da entrevista aspectos do trabalho da ONG que parecem privilegiar "pensar com” os jovens e seus ativismos. Esta situação reflete a mesma apontada por Walsh (2009a) sobre uma das noções da interculturalidade crítica decolonial de "pensar com" os saberes e fazeres dos sujeitos marginalizados, 
alocados em seus espaços periféricos de origem. Ou, como declarou a entrevistada, "pensar com" as "lideranças comunitárias orgânicas".

\subsection{Dados do questionário}

Nesta seção apresento informações declaradas no questionário online que foi referência para a etapa de entrevistas. Ou seja, informações do questionário cujo respondente declara participar dos encontros de planejamento e tomada de decisões do projeto "Ressuscita São Gonçalo" e concordaram em participar da etapa de entrevistas. Tendo por base estas informações se configurou o grupo e compartilho algumas características.

Entre os 11 respondentes que seguiram a etapa de entrevistas, 8 são mulheres e 3 são homens. Destaco a predominância de mulheres autodeclaradas pretas (2) e pardas (3). Quanto aos homens, 1 autodeclarado preto, 1 autodeclarado pardo e 1 autodeclarado branco. Em relação a faixa etária, os/as participantes apresentam idades entre 22 e 45 anos, com maior frequência de participação de jovens com 23 e 24 anos de idade.

Sobre atividades ligadas a formação e experiências de trabalho, dos 11 respondentes, 6 são estudantes do Ensino Superior. Há 2 jovens que concluíram Ensino Médio e 3 jovens que concluíram Ensino Superior. Uma das perguntas do questionário referiu-se à composição e renda familiar. 6 participantes declararam exercer atividade remunerada. Do total de respondentes, a maioria (6) informa renda mensal familiar entre 1 e 3 salários-mínimos ${ }^{40}$. Os dados apontam que a maioria dos/as jovens reside com 2 pessoas ou mais, cuja composição descreve-se, em ordem de recorrência por mãe, irmão/irmã e pai.

Com este panorama, percebe-se que o grupo de entrevistados/as expressa a face nacional da população brasileira que é feminina, autodeclarada preta e parda conforme dados da Pesquisa Nacional por Amostra de Domicílios Contínua

\footnotetext{
40 Sobre renda mensal familiar, a opções de resposta do questionário apresentou-se alinhada ao valor do salário-mínimo de R \$1.045, 00 (mil e quarenta e cinco) em vigor a partir de fevereiro de 2020, conforme Medida Provisória $\mathrm{n}^{\circ} 919$ de 30 de janeiro de 2020. Disponível em https://www.in.gov.br/web/dou/-/medida-provisoria-n-919-de-30-de-janeiro-de2020\%20240824899\#: :text=Di\%C3\%A1rio\%20Oficial\%20da\%20Uni\%C3\%A3o,Publicado\%20em\%3A\%2031\&text=62\%20da\%20Constitui $\% \mathrm{C} 3 \% \mathrm{~A} 7 \% \mathrm{C} 3 \% \mathrm{~A} 3 \mathrm{o} \% 2 \mathrm{C} \% 20 \mathrm{adota} \% 20 \mathrm{a}, \mathrm{e} \% 20$ quarenta\%20e\%20cinco\%20reais Acessado em 15 dez. 2020.
} 
(PNAD) de 201941. Outra dimensão que pode ser observada a partir das informações compartilhadas no questionário é que estes jovens estão inseridos no retrato dos jovens brasileiros que ingressam ao ensino superior através de políticas de cotas e/ou programas sociais como Prouni. Faísca que anima, porém não representa as juventudes periféricas de forma majoritária. Em dados do IBGE divulgados em $2020^{42}$, apesar do aumento dos níveis de escolarização, quase $75 \%$ dos jovens entre 18 e 24 anos estão atrasados ou abandonaram os estudos. O dado se torna mais alarmante quando observado recorte de gênero e de raça, que por exemplo, estão presentes nos jovens deste trabalho.

A partir destes dados, recupero um dos objetivos da investigação que se relaciona a problematizar o fenômeno de engajamento e participação social das juventudes periféricas contemporâneas como efeito inesperado das políticas públicas de acesso ao ensino superior.

As informações obtidas via questionário, além de configuração demográfica, socioeconômica e contextualização social dos participantes acentuaram aspectos de suas biografias que puderam ser aprofundados no diálogo das entrevistas e serão apresentados no item que segue.

\subsection{Dados das entrevistas}

As entrevistas foram analisadas a partir de aspectos identificados como relevantes para conhecer, compreender e visibilizar processos formativos que podem estar desencadeando engajamentos juvenis nas periferias. No que concerne a realização das entrevistas, conforme já foi mencionado, todas elas ocorreram de forma remota. Torna-se oportuno destacar que, em decorrência da necessidade de distanciamento físico provocado pela pandemia, não houve locomoção pelas ruas da cidade. Apesar disso, sublinho que foi possível acessar 10 diferentes bairros do município a partir de informações, perspectivas e experiências compartilhadas pelos sujeitos entrevistados.

\footnotetext{
41 Além de características de domicilio o PNAD contínua investiga e entrecruza dados de cor ou raça dos moradores permitindo entender aspectos democráticos e sociais. Os dados referenciados foram atualizados em maio de 2020 e estão disponíveis em https://biblioteca.ibge.gov.br/visualizacao/livros/liv101707_informativo.pdf Acessado em $28 \mathrm{dez} 2020$.

42 Dados do PNAD Educação 2019 divulgados em julho de 2020 na seção Estatísticas Sociais da plataforma do IBGE. Para mais informações acessar https://agenciadenoticias.ibge.gov.br/agencia-sala-de-imprensa/2013-agencia-de-noticias/releases/28285-pnad-educacao-2019-mais-da-metade-daspessoas-de-25-anos-ou-mais-nao-completaram-o-ensino-medio Acessado em 10 jan 2021.
} 
Para ilustrar o que foi percebido, na figura 12 represento a extensão territorial da cidade e adiciono cor laranja aos bairros em que os/as entrevistados/as declararam residência. Nomeadamente, Boaçú, Gradim, Nova Cidade, Porto da Pedra, Colubandê, Pita, Antonina, Porto da Madama, Pacheco e Centro.

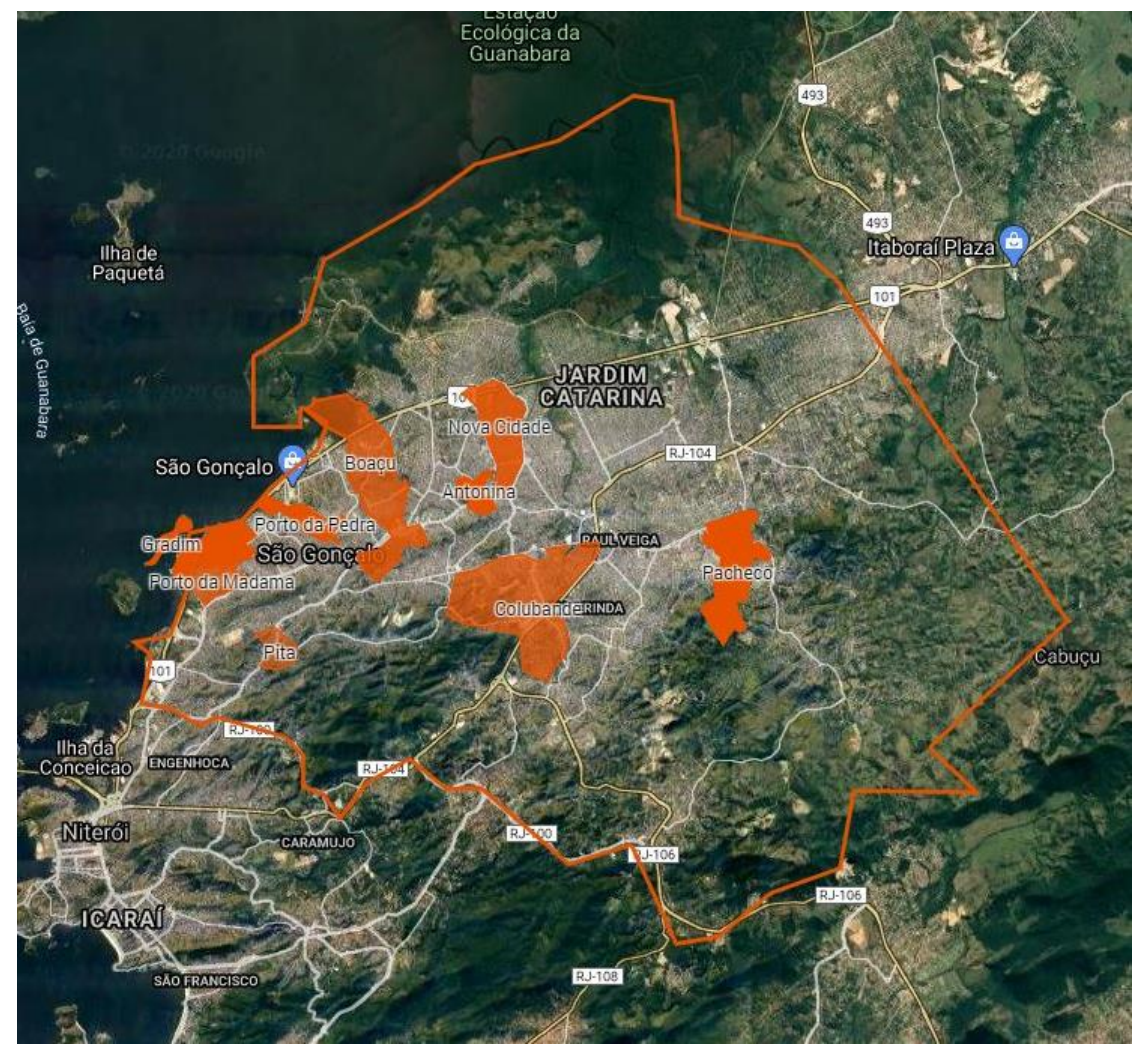

Figura 11 - Representação dos bairros em que residem os entrevistados Fonte: Autora

O que quero provocar com esta representação de ocupação da cidade é um paralelo com dimensões que se apresentam de forma expressiva na fala dos/as jovens entrevistados/as. Um tipo de ocupação não apenas geográfica, mas uma ocupação que coloca o território periférico em cena afetiva. A reflexão de Daniele expressa esta evidência recorrente nos relatos.

É uma relação independente das coisas ruins que aconteceram, talvez ao longo da minha vida. Eu tenho uma relação, é um apego, sabe. Da mesma maneira que eu lembro do quintal da minha avó, talvez não, o quintal não é o mesmo, mas da mesma maneira que eu lembro daquele quintal, que eu tenho uma relação muito boa de apego com ele, de afeto, eu tenho por São Gonçalo. Até porque eu passei por muitos bairros de São Gonçalo. Eu tenho relação com Boaçu, com Porto da Pedra, Brasilândia também, lembrei, já morei na Brasilândia, Minas Gerais [...] Eu já morei em mais de 20 bairros em São Gonçalo. Não, 20 bairros não, 20 casas em São Gonçalo. Então, quando eu ando pela cidade, eu ando no normalmente: já morei aqui! Morei no Canal ali em Neves. Enchia tudo! [...] eu lembro que eu morava no morro assim, que quando tinha invasão, uma vez os bandidos foram parar na minha casa e eu passei a madrugada conversando com os bandidos depois da invasão. Eram umas histórias muito aleatórias assim. Só em São Gonçalo. [...] 
Nossa... quanto foi importante para mim morar no Porto da Pedra. A curva do S. Entendeu a relação que eu tenho com São Gonçalo?

Dessa forma, durante as entrevistas percebeu-se que foi rememorado pelos participantes processos que, para fins de análise, se organizaram, inicialmente, em duas dimensões, sendo elas memórias afetivas e reinterpretações propositivas. Entretanto, tal como Kaufmann (2013), a compreensão do sujeito é um instrumento, o objetivo do/a pesquisador/a é aproximação com explicações do social. À vista disso, revisitei o material mapeado buscando captar fatos, sentidos e elementos que derivassem categorias de análise. Rememorei, inclusive, o diálogo com uma das participantes que "se fosse para pensar em alguma coisa (sobre a pesquisa) ... o ponto chave deveria ser as pessoas que ainda acreditam, porque são as pessoas que tem a cara para mudar São Gonçalo”.

Assim, alguns elementos se destacam em mais de uma entrevista tornando possível agrupar aspectos que transitam nas enunciações dos temas provocados a partir do roteiro semiestruturado. Deste processo emergiram 4 categorias denominadas perceber-se nas incertezas, encontros com a diversidade, perspectivas em ação e microuniversos insurgentes. Tais categorias são, na verdade, ângulos para indicar processos formativos dos/as jovens participantes. Por esta organização pretende-se compreender e visibilizar saberes e fazeres que perpassam passado e presente na constituição das trajetórias dos/as jovens ativistas gonçalenses. Semelhante a isso, Sacavino (2016) afirma que

contar outras histórias ou histórias outras significa apoiar, valorizar e visibilizar a produção e o fazer história dos sujeitos subalternizados e colonizados. Apropriar-se de suas próprias leituras do passado e do presente como uma forma de luta contra as diversas formas de dominação e negação a que foram submetidos (SACAVINO, 2016).

\subsubsection{Perceber-se nas incertezas}

Lembro nitidamente da Van me buscando para ir para o colégio, aqueles buracos ali clássicos daquele lugar. Aquele espaço ali nunca foi um espaço tranquilo. Principalmente depois da ocupação das comunidades no Rio. Isso eu lembro nitidamente, eu não sei... mas eu não vou saber os anos certinhos ... eu lembro de dormir e ouvir motos e motos passando. E olha que eu não morava de frente para você ter noção do quanto que aquilo ali foi simbólico para mim. E aí eu conversava com a minha mãe: "o quê que é isso?", e minha mãe já preocupada querendo se mudar, porque eram as motos de pessoas que estavam fugindo desse momento que 
o Rio estava passando. Aí, depois disso, aquela região ali onde eu morava, nunca mais foi a mesma. Paola

A opção de iniciar as reflexões sobre perceber-se nas incertezas através deste relato é por considerar que este trecho representa bem os aspectos agrupados nesta categoria. De forma bastante semelhante os/as entrevistados/as apresentaram memórias tanto de brincadeiras coletivas quanto hábitos familiares que foram redimensionados conforme o território era ocupado pelo tráfico organizado.

No trecho anterior, Paola concentrou-se no simbolismo do barulho das motos em alta velocidade na rua de seu bairro para demarcar seu espanto diante do aumento da violência urbana na região em que viveu sua infância. Em geral, cada um dos /as jovens sublinha experiências que envolvem episódios cotidianos de insegurança e medo.

Paola não soube "os anos certinhos" para situar na linha do tempo presente sobre qual onda de fuga sua memória repercutia. Entretanto, através do relato de Rafael foi possível cruzar informações entre citação x idade do entrevistado para inferir que se referem as incertezas decorrentes da experiência de implementação das Unidades de Polícia Pacificadora (UPP) em comunidades do Rio de Janeiro a partir dos anos de 2008.

eu tinha uns 13, 14, eu sentei na parte de trás do ônibus e foi uma coisa que me marcou. Eu estava na parte de trás e entraram dois caras ali no ônibus, ficou um do lado direito e outro do meu lado esquerdo. Um estava com alguma coisa estranha, eu criança não sabia, não conseguia entender. Aí um perguntou, gostou né? Aí eu percebi que um estava se drogando com alguma coisa, provavelmente com cocaína um pouco antes de entrar no ônibus. [...] Você criança não vai percebendo tanta coisa dos problemas, a não ser quando a gente entrava em uma viela errada, uma rua errada, e com o tempo isso começou a acontecer mais. Enquanto eu fui crescendo, à medida que eu fui crescendo mais perigoso ficava. Com 11 anos era mais tranquilo, mas com 15 eu já tinha que dormir na casa da minha avó, quando eu estudava... chegar em casa à noite era mais perigoso. [...] Em alguns outros momentos, por morar em local que às vezes tem alguma presença de assalto, morar perto de lugares que tem tráfico de drogas, tive contato ali de passar perto ou de precisar sair andando, sorrir, fingir que não estava nada acontecendo para não ter nenhum problema... Rafael

A partir destes relatos é possível recuperar que, assim como outros municípios periféricos da região metropolitana, a cidade de São Gonçalo, é alcançada mais por erros que acertos das políticas de segurança do Estado. Uma espécie de esperança para manutenção do status de cartão postal da capital carioca, mas para o "lado de cá" regulação e invisibilidade. O "lado de cá" a qual me refiro não apenas 
geográfico como o município é popularmente referenciado pelos que atravessam a Ponte Rio-Niterói. Refiro-me a "este lado" da linha abissal com base nas reflexões de Santos (2007). Sendo o autor, há linhas de poder visíveis e invisíveis que regulam e dividem a sociedade.

Assim, direitos humanos são violados para que possam ser defendidos, a democracia é destruída para que se garanta sua salvaguarda e a vida é eliminada em nome de sua preservação. Linhas abissais são traçadas tanto no sentido literal quanto no metafórico. No sentido literal, são linhas que demarcam fronteiras como vedações e campos de morte; dividem cidades em zonas civilizadas (condomínios fechados em profusão) e zonas selvagens (Santos, 2007, p.78).

Criam-se, portanto, marcos divisórios, como a implementação de políticas públicas para segurança da capital de um lado da linha e "deste lado", acomodam o inapropriado e elimina-se o espaço público produzindo inexistência de práticas como brincadeiras na rua no retorno da escola.

A rua não tinha dono, a rua era... A rua hoje... A rua hoje ela é um caminho de passagem que por acaso tem casas e que por acaso às vezes os vizinhos se encontram. A rua na minha infância era o lugar de encontro. A gente ia pra casa para dormir, a gente ia pra casa para comer, mas a gente vivia na rua. Eram os vizinhos fofocando, eram as crianças brincando, eram as crianças jogando bola, as crianças fazendo um monte de coisa. Então a rua é esse patrimônio familiar, a rua era uma conexão, a rua era uma espécie de corredor de uma grande casa. [...] aí o vizinho vinha com um prato de bolo de aipim e dava para a sua mãe, sua mãe fazia um fricassê e ia para a casa da outra vizinha. [...] Existe um comunismo né no patrimônio da favela. Todo mundo, por mais que não seja dono da propriedade privada do outro, tem influência sobre aquele uso quando existe uma pauta maior. Hoje está muito sério até... Quando vê o polícia e ladrão virou verdade né?! Rodrigo

A gente brincava na rua, mas tinha uma preocupação muito grande dos meus pais, e aí depois meio que confirmou assim, porque a gente mora em uma área que não é muito tranquila, tem o tráfico. [...] É uma questão muito forte daqui, dessa coisa do direto à cidade. É crítico, é bem crítico. Helaine

O relato a seguir evidencia outro aspecto de incertezas. A experiência da entrevistada apresenta convergência com a reflexão de Santos (2007) ao afirmar que "o pensamento abissal moderno se destaca pela capacidade de produzir e radicalizar distinções (p.72) em um "universo que se estende além da legalidade e da ilegalidade [...] juntas essas formas de negação radial produzem ausência de humanidade e subumanidade moderna" (p. 76). Nas palavras de Valda, que é professora

São Gonçalo está muito demarcada territorialmente, a gente até pouco tempo... Está gravando? Por exemplo, cada escola, as diretorias de São Gonçalo são indicações políticas do deputado estadual daqui. Nem eleição a gente tinha na escola. A gente 
tinha que engolir aquela direção e ponto final, porque era uma demarcação política. Política no pior sentido da palavra. [...] É tudo muito assustador nesse sentido. A gente tem muitas... os bairros dos políticos, que parecem facções. Aqui é o pedacinho do deputado fulano de tal, aqui é o pedacinho do vereador fulano de tal, e ninguém resolve nada em sentido do município como um todo...Eu nunca elegi um vereador para a minha cidade, votando a vida inteira aqui eu nunca elegi um prefeito, nunca elegi um vereador. São Gonçalo é uma capitania hereditária.

[...]

A gente tem muitas... os bairros dos políticos, que parecem facções. Aqui é o pedacinho do deputado fulano de tal, aqui é o pedacinho do vereador fulano de tal, e ninguém resolve nada em sentido do município como um todo. eu lembro quando eu trabalhava no Santos Dias e eu fiz uma pesquisa em sala e perguntei em quem eles iriam votar para deputado estadual. Aí era uma cara, um traficante da cidade que todo mundo sabe quem é. Aí eu falei, vocês sabem que ele é traficante? É professora? Mas tem um monte de campanha dele por aí. É, mas ele é traficante. Aí que um aluno falou assim, é, mas foi o traficante que mandou pavimentar minha rua, então eu vou votar nele. Eu sei que uns dois dias depois, uma pessoa falou para mim, "para de falar que ele é traficante, você quer morrer? Quer aparecer assassinada na porta da escola? Todo mundo sabe que o cara é traficante". Ai a gente fica nesse jogo de não pode falar, a gente tem medo e continua votando nessas pessoas. Tem que sair dessa história de que eu vou pavimentar rua, de construir uma assistência social, esse populismo. O politico tem que se comprometer com causas mais efetivas Valda

No que tange ao tema da política representativa, atravessa os relatos dos/as jovens um sentimento semelhante ao abandono diante das incertezas que se desdobram na realidade das exclusões sociais.

A gente não tem um político, como eu já disse, que quer ver de fato a melhoria na cidade. A gente é largado. Largado às traças. Então a gente não vê uma mudança, a gente não vê políticas públicas realmente voltadas para a realidade de São Gonçalo. A gente não tem uma sensação de pertencimento aqui nosso. Todas as pessoas que moram aqui na cidade e ficam bem de vida, vamos dizer assim, saem. Então isso incomoda muito. Você vê os casos de violência aumentando, a educação aqui da cidade é uma vergonha, saúde também você quase não tem. Cultura então! Você tem que sair da cidade para consumir cultura, lazer. Uma cidade que não tem uma biblioteca, um teatro que está feito, mas não foi inaugurado. Então tudo isso vai acumulando dentro das pessoas, não sei, esse sentimento, e as pessoas nem querem mais falar. As pessoas perderam a esperança, porque acham que é assim que vai ficar, entendeu?! Graciele

Ao longo das entrevistas os/as jovens compartilhavam percepções subjetivas e objetivas em contextos de desigualdade social presentes na cidade em que residem. Durante as entrevistas muitos temas foram rememorados. Alguns inclusive à época recente quando mencionam o ingresso no Ensino Superior.

Eu ficava muito preocupada. Eu estava já na faculdade, então não tinha essa preocupação da mensalidade, mas eu ficava muito preocupada, mesmo não tendo mensalidade, tem o custo enorme de ir para o Fundão, que foi aumentando ao longo dos anos. Quando eu entrei no fundão o Bilhete Único era 6,50 e depois 8 e cacetada. Depois que isso aconteceu, pouco tempo depois, eu consegui uma bolsa de iniciação científica que deu uma tranquilizada, porque eu consegui pelo menos 
manter meus gastos de transporte. Aí depois eu consegui uma bolsa de monitoria, quando acabou a de iniciação científica, e eu fui dando meu jeito. Helaine

E tive que sair do trabalho por causa da PUC, porque um professor escroto falou que não tem como você estudar e trabalhar ao mesmo tempo. Ou você estuda, ou você trabalha. O único professor escroto que eu tive nessa faculdade. Odeio ele até hoje [...] Pessoas escrotas, tem pessoas escrotas, desculpa a palavra, tem pessoas escrotas em todos os lugares. Lá não era diferente, tinham pessoas escrotas. Assim, inclusive lá foi até um dos locais ... eu gosto muito desse período que eu passei como modelo de prova, porque foi aonde não fez eu ter essa transição com a PUC, sabe, de: nossa, as pessoas são ricas! Nossa, as pessoas são ricas mesmo! Daniele

O depoimento de Daniele repercute as dificuldades de acesso e permanência no ensino superior conforme apontou as pesquisas de Zago (2006), Carrano; Marinho e Oliveira (2015) e Oliveira e Leão (2019). Reitero que os trechos destacados são os que, na avaliação da autora, expressam notadamente os aspectos apontados nas entrevistas, mas não são os únicos. Perceber-se sujeitado às forças do poder moderno/colonial indicam dimensões de aprender a questionar, inquirir e amplificar suas vozes para a transformação. Em perspectiva abrangente,

Permite considerar a construção de novos marcos epistemológicos que pluralizam, problematizam e desafiam a noção de um pensamento e conhecimento totalitários, únicos e universais, partindo de uma política e ética que sempre mantêm como presentes as relações do poder às quais foram submetidos estes conhecimentos (WALSH, 2009b).

As experiências e percepções relatadas pelos/as jovens indicam transformação das ausências em presenças, conforme postula Santos (2002) ao visibilizar a sociologia das ausências. Nas palavras do autor "só assim será possível evitar o gigantesco desperdício das experiências de que sofremos hoje em dia” (p. 239). As palavras de Aline, aludem a um giro de referenciais sobre a necessidade de um jeito "outro" de pensar e agir no mundo.

quando eu comecei a fazer faculdade e ia pra Niterói todos os dias e voltava para cá, eram dois mundos diferentes. Eu estava ali quase em Icaraí, eu estava na Escola de Engenharia da UFF, de frente para a baía de Guanabara, ali para a praia, para o MAC, e eu voltava para casa e via outro mundo completamente diferente. Eu falo que essa realidade... os olhos sangram, figurativamente, porque é um outro mundo, cada dia você passa menos a reconhecer o lugar onde você mora, porque nesses meus encontros de vida, refletindo sobre isso, quando eu era pequena, eu não achava aqui estranho, eu achava aqui normal. Era o mundo que eu conhecia. Tudo aqui era normal. Não ter coisas era normal, não ter asfalto era normal, não ter eventualmente uma luz no poste era normal, poeirada passando ônibus, tudo normal. Aí você pega e essa pessoa tipo vai para a zona sul de Niterói, MAC, escola de engenharia, Icaraí, a cabeça da pessoa fica totalmente, o referencial é outro. [...] Aline 


\subsubsection{Encontros com a diversidade}

Durante as entrevistas, diferentes aspectos de encontros foram relatados. Alguns jovens expressaram memórias vinculadas a práticas escolares e professores/as. Desta forma, nesta categoria, trata-se, portanto, de destacar depoimentos dos jovens sobre encontros transformadores ou, como expressa Aline, algo que "mudou minha vida pra sempre", ao lembrar de um encontro com sua professora.

Eu estudava em um colégio, estava fazendo a oitava série e aí eu não tinha condições de pagar os cursos preparatórios para os principais colégios, Pedro II, FAETEC, que tem cursinhos na área, tem cursinhos em Alcântara, e eu não tinha condições de pagar. Eu também não tinha muita informação. Eu ia na lan house, não tinha internet em casa naquela época, isso em 2010. Eu não tinha internet em casa, inclusive eu fiz uns hackers assim dentro de casa, eu fiz um modem, adaptei um modem e aí eu pagava a internet [...] eu ia na lan house e eu não tinha muito material, não tinha esses cursos que eram relativamente caros na época, tinha alguns conhecidos fazendo e eu falei, vou continuar fazendo o ensino médio aqui nesse colégio e é isso. E aí um dia chegou uma professora falando que tinha o processo seletivo, e ela foi de sala em sala, ela não era da nossa escola, foi de sala em sala falando "gente, tem um processo seletivo para as escolas de ensino integrado. Tem o NAVE, o NATA, o ERIC, que é um de administração lá em Santa Cruz e é de graça, façam, escolham um curso, faz a prova, não custa nada". E ai aquilo brilhou nos meus olhos, uma chance de quase última hora, estava no meio do ano, o pessoal do Pedro II se preparando desde que começou e eu falei, ah vou tentar [...] e aí eu passei. Passei na primeira turma mesmo, na primeira classificação. E aí para mim, assim, foi um momento marcante. Eu lembro dela, mas eu não sei o nome, não sei quem é, e ela tirou o tempo para falar dessa oportunidade com a gente, mudou a minha vida para sempre. Aline

Das mudanças objetivas no percurso de escolarização de Aline à desconstrução de estereótipos e aproximação com pautas sociais e políticas no trecho a seguir descrito por Luana, o espaço escolar mostrou-se lugar e tempo de troca cultural, afetos e embates sociais.

No Pedro II tinha de tudo e as pessoas não se estranhavam por isso. [...] eu via os estudantes interessados, se mobilizando para fazer uma greve dentro da própria escola. Uma vez a gente fez um boicote à cantina para baixar o preço do salgado. Deu certo. E eu via os estudantes fazendo eleição de grêmio estudantil e aí eu via projetos diferentes acontecendo na escola, projetos culturais, projetos científicos. Então eu fui vendo que dá para fazer muita coisa além de ir para a escola, assistir aula e voltar para casa. [...] Depois da primeira greve eu comecei a prestar atenção um pouco mais em política, eu comecei a ter contato com... não ter contato, mas a ter mais noção de que existiam movimentos sociais. A partir dos outros colegas, acompanhando o que eles postavam nas redes sociais, eu entendi que existe o feminismo, o movimento negro, o movimento LGBT. Então eu fui mudando a minha visão diante de algumas coisas. Aqui em casa foi uma criação conservadora, muito na base do não pode, é errado. 
Ao longo dos relatos os encontros assumem diferentes dimensões da diversidade e interrelacionam-se nas complexidades sociais. Diferentes sujeitos em diferentes espaços parecem reposicionar ideias e posicionamentos conforme rememorados. Está presente no relato de Rodrigo, por exemplo, uma diversidade que, conforme ele mesmo reflete, enquanto patrimônio específico dos territórios populares.

"ser jovem em São Gonçalo é você ter acesso a essa diversidade. Uma diversidade de pessoas absurda, obviamente com uma limitação econômica gigante também, mas as vivências que você tem são sempre muito ricas por aqui. Amigos, casas, comidas, repertórios de conhecimento, isso é muito forte. [...] Você tem, assim, uma diversidade geográfica para você aprender coisas interessantíssimas...feijões diferentes, saladas de legumes diferentes, comidas diferentes... repertório diverso, cada mãe veio de um lugar. Você aprende uma relação de amizade muito forte, que amizade não é um ativo da sua vida, é um ativo... É um patrimônio familiar. Amizade para quem é de São Gonçalo não é patrimônio individual, é patrimônio familiar. As amizades passam de geração para geração. Você olha para uma casa e você lembra que aquelas pessoas são amigos dos seus pais, e você tem carinho por aquelas pessoas com que às vezes você nunca falou. Então acho que esse patrimônio também familiar é enorme, e aí longe dessa ideia de família tradicional brasileira, eu gosto do conceito de família tradicional gonçalense, eu vou usar isso, eu vou defender isso pra sempre. A ideia de família tradicional gonçalense...

As reflexões de Rodrigo durante a entrevista associam-se também à defesa da "diferença como riquezas que ampliam nossas experiências, dilatam nossa sensibilidade e nos convidam a potencializá-las como exigência da construção de um mundo mais igualitário" (CANDAU, 2016a , p. 809). Reiterando a potência da perspectiva da diversidade para compreender a heterogeneidade de situações e experiências que acompanham as juventudes contemporâneas (SPOSITO, 2000).

A narrativa dos encontros relatados pelos/as entrevistados/as apresentam-se também em temas viscerais ao contexto das desigualdades sociais como as relações étnico-raciais, racismo, aceitação da diferença, reações de intolerância e presença e/ou ausência de representatividade racial.

A diferença é importante. Perceba: a diferença é importante. Diferença de gosto de cor, de gosto musical, de gosto estético, acho isso muito importante. Porém diversidade de acesso aos meios de produção que permitem você ter gosto diferente, isso é um problema grave. Então por quê que de repente é difícil ver um menino da favela gostando de música clássica? É obvio que... Pô, o funk é legal, tem gente que acha o funk muito mais legal. Mas não ter acesso a um piano de cauda, não ter acesso a um violino, não conhecer esses instrumentos ao longo da sua infância, vai fazer ele ter uma rejeição natural àquela linguagem artística ou uma negação, ou um afastamento, e isso vai fazer com que ele não tenha oportunidade, direito de escolher entre o funk, o pagode e a música clássica. [...] No meu caso, eu gosto do 
Raimundos. É meu direito gostar de rock também, e se eu gostar de rock de pessoas brancas ok. E se eu quiser discutir música clássica ok. Eu não preciso ficar discutindo capoeira o tempo inteiro. Eu não preciso ficar discutindo candomblé e umbanda o tempo inteiro. Eu não preciso ficar discutindo escravidão o tempo inteiro. [...] O mano Brown ele fala em um papo com o João Bosco sobre a questão racial, e às vezes... Toda hora a gente fica falando sobre a questão racial do ponto de vista de ancestralidade. Toda hora vem alguém... E eu mesmo sou uma pessoa muito... Meio crítica a...E aí ás vezes nego vem: "Rodrigo, a gente precisa se conectar com a África". E aí eu pego esse papo do mano Brown, pego o poema do Emicida que é 'a África para mim é um não lugar'. 'A África é um lugar que a gente foi retirado de lá'. Eu não sei viver, não conheço nada da África. Eu não conheço nada da África e hoje não me esforço muito para conhecer nada da África, não me esforço para conhecer nada da Europa, eu não me esforço para conhecer nada dos Estados Unidos. Porque esses lugares são não lugares para mim, muito embora a África tenha uma conexão histórica talvez com essa questão da ancestralidade. Mas a ancestralidade já está impressa na pele de quem é preto. Então eu já estou... A minha existência já me conecta com a minha ancestralidade. E ai eu quero me conectar com o futuro. Saindo desse não lugar, eu quero o meu lugar. O meu lugar enquanto território... [...] Eu quero saber outras coisas. Eu quero saber o que essa pessoa pensa sobre comida, gastronomia, música. Isso me interessa, tem a ver com o futuro. E a cidade que eu quero é que pense no futuro. Como que você não sabe discutir jogos eletrônicos, porta eletrônicos, como que você não sabe discutir desenvolvimento tecnológico, mas também desenvolvimento social, desenvolvimento de direitos humanos, coisas do futuro coisas que estão conectadas com o nosso futuro, não com o nosso passado somente. Nosso passado é importante para a gente saber a história né, a trajetória, o rumo das coisas. Mas eu estou muito preocupado com essa conexão. Eu acho que São Gonçalo me leva para o futuro também. São Gonçalo é o meu lugar. São Gonçalo não é um não lugar para mim. [...] Eu esqueci o nome da parada, yopo...(?), sei lá o nome do bagulho. Que fala sobre crença limitante. Cara, quando a gente se depara com uma pessoa que passa por algum tipo de preconceito e a gente resume a pessoa por esse tema, a gente tem um outro problema, que a gente inviabiliza o pensamento aprimorado dessa pessoa sobre outras questões. Rodrigo

O que Rodrigo problematiza como "inviabilizar o pensamento aprimorado" relaciona-se com as experiências relatadas com e a partir de Kilomba (2019) em episódios de violências estruturadas que regulam quem pode falar e sobre o que se pode falar. Segundo a autora, qualquer saber que não se enquadra na ordem de curiosidade, desejo ou permissão eurocêntrica dominante é rejeitada e desvalidada cotidianamente. Em sua obra "Memórias da plantação, episódios de racismo cotidiano", Kilomba (2019) compila reflexões a partir de situações cotidianas de silenciamento e subalternidade a mulheres e homens racializados, a exemplos como o de Rodrigo ao ser interpelado sobre o que deve ou não compartilhar em suas redes sociais.

O fato de Rodrigo "querer saber sobre comida, gastronomia, música” e expressar que "não preciso ficar discutindo candomblé e umbanda o tempo inteiro" sugere enfrentamento às situações de violência epistêmica. O relato de "exigência" 
descrito por Rodrigo é exemplo do que Kilomba (2019) denomina "performando negritude". Para a autora esta condição de "ter que representar a raça" já anuncia racismo. A cena se torna "um círculo duplo, de inclusão e exclusão" que limita Rodrigo a representar aquilo que ele significa, "raça". Ao longo das entrevistas evidenciou-se uma espécie de encadeamento entre resistência e insurgência que sublinha novas formas de construção de sentido.

A partir e com o relato de Daniele é possível tomar contato com a realidade condicionante da modernidade/colonialidade. Ao descrever sua chegada a universidade a entrevistada reflete sobre os momentos de solidão e tensão entre regulação/emancipação social.

A PUC ser a PUC, eu digo, o nome da instituição. Eu não tinha noção do peso que a PUC tinha, o nome da instituição. E não tinha noção o pessoal fala assim, por exemplo, eu vejo hoje, eu falo: eu faço PUC, as pessoas dizem: ah, que patricinha. Eu falo: gente, eu sou bolsista! Mas mesmo sendo bolsista, eu não sabia que tinha aluno rico, eu não sabia, não notava isso a princípio. E eu só fiquei assim porque era muita gente branca, isso eu lembro. Eu mandei foto para minha família: gente, eu nunca vi tanta gente branca na minha vida. Gente, isso é muito assustador para mim. E era gente branca, gente branca de verdade. A única coisa que eu posso dizer que na PUC, eu falei: que lugar é esse? Foi a quantidade de pessoas brancas. E muito brancas, porque é diferente do branco de São Gonçalo. São Gonçalo tem gente branca, mas não é branco, branco, que nem lá na PUC que eu via gente branca. Daniele

Esta fala de Daniele reitera a cotidianidade dos casos de racismo e sua estrutura sistemática de discriminação como denuncia as reflexões de Almeida (2018). Para o autor, o racismo "é uma forma sistemática de discriminação que tem a raça como fundamento, e que se manifesta por meio de práticas conscientes ou inconscientes que culminam em desvantagens ou privilégios, a depender ao grupo racial ao qual pertençam". O trecho que descreve a chegada de Daniele a universidade não é o único episódio em sua trajetória. Em experiência profissional como modelo de prova há mais uma reflexão sobre um tipo de isolamento social em que a jovem encontrou-se "atravessando as fronteiras da hostilidade" (KILOMBA, 2019, p. 169).

eu ia para o showroom para ser modelo deles, cara, eu olhava para as vendedoras, eram brancas e eram brancas com a mesma idade. São brancas, mas não são meninas novas. São brancas de 30 a 40, mais ou menos, sabe porque era mulher Sacada, com cara de plena, sem preocupação, sem conta, só vou fazer a unha no salão, vou para o clube... Eu perguntei o porquê, não porque eram brancas, mas porque eram assim, por que a mulher Sacada era essa. Ué! Porque a marca tem que representar a mulher que eles estão... o público-alvo deles. Qual o público alvo deles? Classe média alta, você entende que é o que? Uma mulher branca, no caso 
deles, de 30 anos, porque as mais novinhas tipo 16, 17, 18, 19, 20 seria a Oh Boy que é para o público mais jovem. As estampas mais coloridas, chamativas, descoladas. A sacada eram estampas sóbrias, uma mulher que passe serenidade, tudo mais. Então foi onde eu falei: meu Deus, o que que é isso? Foi aonde eu parei para ter noção de como é que era lá embaixo a produção, como é que era o estilo e como é que era loja. E tecnicamente eu, como mulher negra, só estava ali porque meu corpo batia com todas as medidas que eles precisavam. Daniele

Como ficou evidente nos fatos relatados não há neutralidade no fato de "lá embaixo" ser a produção vinculado a realidade de que Daniele "só estava ali porque seu corpo batia com todas as medidas". Ainda que não haja manifestação verbal de discriminação, há sérios problemas "inventados" ${ }^{43}$ que historicamente silenciam, minorizam, quando não exterminam a população negra. Por meio dos trechos destacados é possível perceber a estrutura central do racismo que nega a existência do que é outro.
"não é possivel que de uma turma de quarenta alunos, três pessoas serem negras retintas e essas três pessoas passarem por situações, sabe, de humilhação. Então a gente vê aqueles apelidos racistas, eu lembro que chamavam ele de "negueba", e eu ficava: "meu Deus"! Também vi... E aí vi piadas referentes a cabelos de algumas meninas. São coisas que a gente... Foram percepções, na verdade não são percepções, foram coisas óbvias que eu via na escola. E via... claro, tipo, era um ambiente muito de paquerinha, tinha muito isso na escola. E você via claramente que essas pessoas negras que eram escolhidas, assim...pouco escolhidas. Paola

É possível identificar a forma visceral em que o racismo está estabelecido nas relações sociais e que ainda há encontros que fatalmente reproduzem discriminação e exclusões. Observa-se também que as juventudes entrevistadas apresentam em suas falas embates e denúncias adicionadas a um chamamento a desnaturalização e visibilidade de suas perspectivas. Reflexões que convocam práticas políticas e pedagógicas de contestação da realidade e afirmação das diferenças. Como apresentadas na reflexão de Paola.

uma professora minha...ela foi uma pessoa muito importante para mim, uma professora incrivel, assim. E sempre conversou muito comigo, sempre esteve muito disposta a dialogar, e aí foi nela que eu me inspirei. Eu acho que eu sempre, assim, depositei muito a minha admiração em mulheres. Eu não sei por que, mas... Ou talvez por ter uma relação tão boa com a minha mãe, mas as minhas principais influências são mulheres. Isso é uma coisa que eu não preciso fazer um esforço. Então ver nela uma mulher articulada, tipo, uma mulher preta super empoderada, dentro de um colégio que a gente nem via gente preta no colégio. Sério, durante muitos anos eu era a pessoa, tipo assim, preta, mas ninguém vinha dizer que eu era preta, mas assim... Bizarro! Nisso o colégio não me ajudou, que foi me conhecer. Mas acho que nenhum colégio ajuda nisso né, é um processo individual. Mas ver

43 Santiago Castro-Gómez propõe em seu texto "Ciências sociais, violência epistêmica e o problema da 'invenção do outro"” (2015) uma análise instigante sobre o problema da invenção do outro imposta ao imaginário coletivo para condenar e encobrir o que é não-europeu. 
nela uma pessoa tão diferente que ao mesmo tempo se destacava e tinha a admiração de todo mundo, e eu falei: "caraca! Essa mulher aí merece que eu a coloque lá em cima". Enfim, eu acho que a minha admiração por ela era tanta, que ela nem precisava fazer muito. Mas ela fazia! Paola

O depoimento de Paola contém segmentos de lamento pela ausência de práticas escolares afirmativas e vergonha pelos que praticam apelidos racialmente depreciativos. Além disso a presença de certa ternura pelo encontro e convivência com uma professora negra que fortaleceu sonhos e inspirou escolhas profissionais. A partir desses elementos, outros sentidos se abrem quando ouvimos as vítimas. Dessa forma algumas reflexões podem ser aprofundadas a partir do exercício da escuta.

Evidente que a temática da representatividade é importante, sobretudo para que homens e mulheres negros e negras ocupem devidas posições de saber, poder e decisão na sociedade. Contudo, é pertinente admitir a reflexão de Almeida (2018) sobre representatividade. Em sua obra "O que é racismo estrutural”, o referido autor sublinha que a luta por representação não levará a superação do racismo, uma vez que o racismo está na forma de entender as relações sociais. Segundo Almeida (2018) o apelo midiático de que "representatividade importa" seria uma estratégia para minimizar históricas lutas e resistências do movimento negro, movimento sobre o qual reconhecemos ser grande educador tal qual reflexões de Gomes $(2017)^{44}$.

O relato de Paola parece catalisar, a partir de sua experiência, a necessidade de experiências "outras”. Tal qual a proposta de Walsh; Oliveira e Candau (2018) ao argumentar sobre práticas sociais e pedagógicas que favoreçam relações igualitárias e horizontes de esperança em vias de romper com estruturas que subalternizam. Nas palavras dos autores, a proposta da interculturalidade crítica aposta na pedagogia decolonial e

convoca os conhecimentos subordinados pela colonialidade do poder e do saber, dialoga com as experiências críticas e políticas que se conectam com as ações transformadoras dos movimentos sociais, é enraizada nas lutas e práxis de povos colonizados e, é pensada com e a partir das condições dos colonizados pela modernidade ocidental. Assim, o pedagógico e o decolonial se constituem enquanto projeto político a serem construídos nas escolas, nas universidades, nos movimentos sociais, nas comunidades negras e indígenas, nas ruas etc.

44 Nilma Lino Gomes é autora da obra “O movimento negro educador. Saberes construídos na luta por emancipação”, Petrópolis, RJ: vozes, 2017. O livro expressa o lugar do movimento negro em ação de educar a partir da luta por emancipação histórica das populações negras desde a diáspora. 
O que se defende é que a pedagogia decolonial torna-se, então, ocasião de encontro entre práticas políticas e pedagógicas para agenciamento à emancipação social. Cabendo às instituições de ensino, entre escolas e universidades, uma oportunidade de reinvenção contra hegemônica que pode favorecer entusiasmo político a estudantes (CÂMARA, 2019). Em outras palavras, práticas sociais e pedagógicas que se ocupam em visibilizar o vívido, a diferença em leitura positiva, os dilemas contemporâneos e as descontinuidades do sistema moderno/colonial que forjam as trajetórias das vozes do sul global, neste trabalho, as juventudes gonçalenses.

\subsubsection{Perspectivas em ação}

$\mathrm{Na}$ categoria perspectivas em ação disponho trechos que referenciam ocorrências de potencialidades à ação identificadas nas narrativas dos/as entrevistados/as. Alguns dos trechos parecem responder a convocação feita por Quijano (2005) sobre o eurocentrismo e as consequências do colonialismo que reverberam nas dinâmicas do atual padrão de poder moderno/colonial.

O referido autor, ao argumentar sobre a colonialidade do poder, expressa a potencialidade do projeto decolonial e que seu avanço, a decolonialidade da sociedade, é consequente a "aprendermos a nos libertar do espelho eurocêntrico onde nossa imagem é sempre, necessariamente, distorcida (p. 139)". A reflexão de Rafael parece associar-se a esta ideia de que "é tempo, enfim, de deixar de ser o que não somos" (QUIJANO, 2005, p. 139).

A gente sentia e sente até hoje que a gente não conversa sobre São Gonçalo. A gente conversa sobre o Rio de Janeiro, os problemas do Rio de Janeiro, o prefeito do Rio de Janeiro, o governador, presidente, mas a gente não consegue olhar para nós mesmos aqui dentro [...] São Gonçalo não é uma cidade dormitório, mas ela dorme quando é convidada a olhar para ela mesma. Ela não olha para dentro dela mesma. [...] São Gonçalo, como uma cidade periférica, acompanha essa realidade que existe muita das vezes em várias favelas e territórios periféricos do Rio de Janeiro, no Brasil e no mundo também. [...] infelizmente a gente não tem como... você vive em uma sociedade que reproduz o patriarcado, reproduz o racismo, só é possível sair um pouco dessa realidade se você tem política pública que realmente enfrente aquilo [...] olhando a memória da cidade... a gente precisa ressuscitar enquanto cidade e sair dessa dormência, a gente precisava discutir, então é muito disso. Não é nem uma questão de morte, é uma questão de dormência, a cidade nunca morre, mas ela pode adormecer em alguns momentos [...] A nossa câmara de vereadores, atualmente, ela é $100 \%$ composta por homens neste momento em São Gonçalo. Até onde eu sei, a gente tem dois vereadores, de um a dois vereadores negros, se tiver. 
Certamente a gente não tem uma quantidade de pessoas, uma característica na câmara de vereadores que representa a população de São Gonçalo, que é de maioria negro e pardo, a maioria de mulheres, a gente não tem isso lá na câmara. Além dessas questões relacionadas à diversidade, todas as pessoas que estão lá, a maioria de pessoas que chegam na câmara são pessoas que já tem uma relação com vereador, ou são filhos de vereador, parentes ... somente com pessoas que representam a cidade, as pessoas da cidade nesse espaço é possível trazer algumas modificações para São Gonçalo. Como em qualquer outra cidade e o próprio Brasil. Rafael

As entrevistas, diga-se, todas as entrevistas, apresentam considerações e apreensões sobre as feridas provocadas pelas desigualdades sociais. Há nos relatos ponderações e análises sobre a emergência de um projeto político social de transformação, especialmente, a partir do território. De maneira geral, os/as jovens entrevistados/as expressam intenções de anunciar, afetar e reunir mais pessoas a fim de coletivizar suas ideias e posicionamentos. Há trechos, inclusive, em que os entrevistados demarcam, dentro do próprio grupo de afinidades, valores aos quais não abrem mão, como na descrição de Helaine.

Tinha uma galera que eu não concordava muito com o posicionamento político. Rolou um estresse de falar mal de universidade federal e eu não gostei. Porque eu acho que assim, eu acho que a gente tem que caminhar... ainda mais com um grupo ...tem que caminhar com alguém que está na mesma direção que você, pois se a pessoa fala pelo grupo, ela fala por você também. Aí acabou acontecendo, foi bem naquele período de eleição presidencial, que foi bem conturbado.

Quando refletem sobre suas motivações à ação apreciam a relação formativa que estabeleceram com a cidade. Vale a pena registrar o quanto demonstram estar mergulhados em seus projetos, ativismos e sonhos. Animada com sua reflexão, Daniele expressa

não sei explicar, sabe é um saudosismo que eu tenho pela cidade. Como se eu tivesse essa responsabilidade com ela, por ela...ela ter formado tanto do meu caráter. Inclusive essa é uma das coisas que eu brigo com quem nega que mora em São Gonçalo. [...] Até nas coisas ruins que a cidade, sei lá... [...] poxa, pensa bem, o quanto não seria inovador criar, mapear a cidade, você passar um questionário conhecer os bairros... conseguir pelo menos falar, ter contato com a realidade das pessoas de cada bairro. Você entender como é que funciona o saneamento, distribuição de água, é.... saneamento distribuição de água está envolvido, mas eletricidade, asfaltamento, coleta de lixo. Você conseguir realmente conhecer a sua cidade e você pensar uma política pública a partir dela, e não uma política pública pensada, sei lá, por um conjunto de pessoas que talvez nem moram na cidade. Daniele

Estes e muitos outros desejos acompanham os relatos que denotam intenção de movimento e mobilização. Destaco a elaboração das argumentações que se 
apresentam nas reflexões sobre a contribuição de suas trajetórias com e para a cidade.

Você saber realmente da boca do morador da cidade que mora aqui há mais de trinta, quarenta anos, é muito mais legal do que você saber da boca de um jornal, ou de um político. E para mim, vou dizer, porque você saber que você está fazendo um projeto que agrega, que a partir disso talvez tenham jovens ou pessoas mais velhas que queiram participar do projeto...ou que... Ou os senhores também que acreditam na juventude, que diferente da geração deles, a gente pode fazer algo melhor...Nossa! Graciele

O entusiasmo de Graciele ao pensar nas proposições do grupo com e a partir do território parecem constituir o aquecimento da razão defendido por Santos (2019). Nas palavras do autor

o aquecimento da razão é o processo através do qual as ideias e os conceitos continuam a despertar emoções criativas e capacitadoras que reforçam a determinação de lutar e a disponibilidade para correr risco [...] o aquecimento não dispensa ideias, conceitos e teorias; apenas transforma problemas e desafios vitais em experiências concretas de expectativas próximas, seja para se lutar contra elas seja para se lutar por elas (SANTOS, 2019, p. 150).

Dessa forma, do ponto de vista das epistemologias do sul, a luta depende sempre de uma vontade que sustenta o modo imperativo de lutar e afetar individual e coletivamente o território, como nas palavras de Graciele "a missão de conseguir impactar pelo menos um estudante e adolescente, e ele ver: "caraca é possível para mim alcançar o mundo". Em outros termos, saberes e fazeres transformando latência em potência, ausência em emergência evidenciando um tipo de "fusão entre razões e emoções, dando origem a motivações e expectativas capacitadoras" (SANTOS, 2019, p. 153) denominadas por Santos (2019) como corazonar.

Os trechos que seguem evidenciam razões e emoções em perspectivas de ação no "Laboratório de Análise Covid-19" organizado pelos jovens no período inicial da pandemia, conforme notas das observações (seção 5.1.2) "Estreitando inquietudes". Na medida em que as entrevistas ocorreram, concomitante ao período da referida atividade, os/as jovens expressavam preocupações sobre possíveis colapsos globais buscando compreender repercussões locais numa espécie de sercom a realidade.

No primeiro trecho Gisele, que é nutricionista, compartilha sobre sua experiência em levantar informações sobre o kit merenda distribuído pela prefeitura municipal aos estudantes da rede pública de ensino. 
Eu me dei conta que a gente tem sido violado o tempo inteiro, em relação a direitos. Isso é uma coisa que não fica evidente para a população. Muita gente fala assim, ah, mas você quer um Estado babá. Essa fala vem muito forte de todo mundo. Mas não, a gente vive nessa relação de Estado. O estado deve coisas a gente. Isso é garantido na constituição, no papel. Se isso não é garantido na vida pessoal, todo cidadão tem direito e deve fazer esse tipo de denúncia, quando tem essa violação. Por não saberem disso, as pessoas não fazem denúncia...parece que elas não querem perder tempo, trabalhar nisso. A área de alimentação e nutrição, ela se relaciona com vários dos direitos, tanto direito à saúde, quanto direito à educação, moradia, transporte, atividade física. Então essa noção de direitos que conversam com a parte de nutrição é muito ampla, não só em relação a alimentos, mas em outros setores da vida que devem ser garantidos para ter uma saúde plena. Então, isso de violação o tempo inteiro, quem estuda isso se vê na necessidade de fazer alguma coisa, de alertar a população, olha isso aqui é um direito, então, isso aqui tem que ser seguido, você não está fazendo demais, só está exigindo o que é seu. Não é pedir favor, então isso está muito no imaginário das pessoas e a gente tenta trazer isso à tona. Se está escrito na constituição, o Estado tem que fazer. Você não está pedindo favor, está pedindo o que é de direito. Nessas violações eu fico muito pensativa em relação a isso. Gisele

No trecho a seguir, Helaine, que é estudante de arquitetura e urbanismo, reflete sobre possível integração entre as experiências acadêmicas e as experiências de ser jovem em território periférico. Reiteradas vezes a entrevistada releva inquietações advindas de interpretações da realidade e possibilidades de projetos mais amplos e eficientes de mobilidade urbana, especialmente no período da pandemia.

Eu estou no grupo que está estudando as questões urbanas, a gente fez um levantamento de todos os grupos e aí dentro dos grupos as empresas, as linhas de onnibus. A gente tentou entrar em contato com as empresas para saber o quanto tinha reduzido exatamente da porcentagem das linhas por causa da pandemia, quais linhas estavam rodando e quais não estavam. A gente não conseguiu o contato. Impressionante! Aí a gente montou um questionário e a gente está compartilhando esse questionário com quem continua se locomovendo na pandemia, para a gente entender como as rotas dessas pessoas mudaram aqui em São Gonçalo. Então, se a pessoa pegava um ônibus e agora pega dois, se a pessoa está tendo que ir para um outro bairro pegar um ônibus que não pegava antes... Será que reduzir a frota fez os ônibus andarem mais cheios? Isso não seria uma medida inteligente, os ônibus mais cheios, em termos de contágio e contaminação. A ideia era fazer esse levantamento para entender se essa medida no nosso grupo em relação à mobilidade, se ela foi eficiente ou se ela mais atrapalhou do que ajudou, se atrapalhou o cotidiano das pessoas, se aumentou as contaminações. [...] É isso, fazer chegar à população a problematizar o que esses serviços que elas pagam, que elas consomem oferecem para elas. Uma ideia de criticidade, enfim, o "Ressuscita" é por aí mesmo. [...] A gente acaba ficando refém, ainda mais assim, a população periférica, pobre, tipo, vai ficar em casa? Não vai pagar passagem? Vai boicotar passagem? É bizarro assim, você não tem como dizer não. [...]. Fazer essa busca...Isso muda a sua forma de enxergar o mundo. Quando você começa a pegar esses dados e entender como uma coisa está ligada à outra, isso muda completamente a visão de tudo, é muito louco, parece que não dá pra desver. Helaine 
O encontro dos saberes comunitários com os saberes acadêmicos apontados por Helaine são compreendidos pela própria entrevistada como uma mudança de ótica sobre o cotidiano. A apropriação dos conhecimentos parecem colocar suas reflexões em perspectivas de ação para a cidade em circunstâncias que "parece que não dá pra desver". Uma espécie de assimilação entre reinvindicações, pensamentos e vivência. Assemelhando-se à reflexão de Mische (1997) de que significações dos múltiplos laços sociais tornar-se-iam caminhos pedagógicos no percurso de estudantes a cidadãos.

Para Rafael, "talvez a universidade tenha esse papel de ampliar a visão das pessoas e dar ferramentas para a gente construir aquilo que a gente acredita ou que aprende". O que na concepção das epistemologias do Sul é a possibilidade de uma "ecologia de saberes" em que conhecimentos comunitários e conhecimentos acadêmicos, posto que ambos são incompletos, complementam-se para enriquecer as lutas sociais. A ecologia de saberes é então um encontro de conhecimentos que constroem outros conhecimentos (SANTOS, 2019).

Por outro lado, Rafael pondera e tece importantes considerações sobre a produção do conhecimento acadêmico e sua relação com o cotidiano da sociedade.

A universidade, ainda assim, é muito presa dentro dela mesma, e quando você coloca a pessoa... isso que percebi muito em ralação com o [Projeto] Manivela...pessoas que de alguma forma sofrem com distância ou as questões relativas à desigualdade de gênero ou do racismo mesmo, que sofrem com a desigualdade social, e você insere essas pessoas dentro da universidade... e essas pessoas conseguem entrar ... ali dentro você consegue ver, essas pessoas sentem uma vontade de retornar aquele conhecimento para onde ela vive, e aí na maioria das vezes aquele conhecimento fica preso lá dentro. Isso é um caminho sem volta. Quando você coloca pessoas que não são necessariamente aquele público, digamos, normal, normalizado dentro da Universidade, como foi historicamente no Brasil, quando se coloca pessoas que são diferentes, você coloca na universidade essa diversidade... tende a se propagar no restante da sociedade. [...] Rafael

A reflexão do entrevistado parece convergir com a crítica de Santos (2019) ao colonialismo que não terminou com o fim do colonialismo histórico e prossegue subalternizando e invisibilizando biografias, bibliotecas e conhecimentos outros na universidade. De acordo o referido autor, para ajustar as contas com o passado de negações não é criar um outro sistema de dominação, mas dialogar com as epistemologias do Sul para a emergência dos conhecimentos alternativos no centro da produção acadêmica. 
Uma base teórico-prática que identifique a linha abissal adicionada a um currículo com a co-presença de diferentes conhecimentos contribuiria para uma universidade "empenhada e polifônica". Nas palavras de Santos (2019), uma universidade "que longe de ser neutra, se empenha em lutas sociais contra o capitalismo, o colonialismo e o patriarcado" (p. 385).

\title{
5.4.4 Microuniversos insurgentes
}

Em vários momentos de seus relatos, os participantes notabilizam que o comum e o ordinário não podem ser subestimados no projeto de transformação social. Rodrigo, por exemplo, evidencia que "a participação simples... popular é uma pílula necessária demais" nos contextos de enfrentamento político para ultrapassagem da colonialidade presente nas interações cotidianas. $\mathrm{O}$ participante sugere, inclusive, que pesquisas acadêmicas levem em conta que há diferentes formas de contribuir para a transformação social dos territórios periféricos. Segundo as reflexões do participante

\begin{abstract}
é sempre importante quando a gente vai fazer pesquisa ou vai se envolver com o território... é a gente tentar evitar ao máximo colocar nossos esforços de achar que quem está mudando a cidade são só os projetos que se propõem a fazer algo. As pessoas elas são de uma transformação muito significativas e dão contribuições excelentes que no todo isso ajuda a mudar uma cidade. Assim como o Rafael está fazendo um trabalho excelente com o "Ressuscita", a mãe do Rafael que não é militante na rua, mas que coloca todo dia almoço para o Rafael comer, ela também contribui porque ela está alimentando um menino muito inteligente e muito promissor para a cidade... a cadeia produtiva das mudanças que uma cidade precisa se dá em várias esferas e não necessariamente são só dos projetos que tem nome, que tem objetivo e que tem ali visão, valores dessa coisa mais tradicional de ver um projeto. Todo mundo, de alguma maneira, contribui para a cidade dentro do seu quadrado, dentro da sua maneira de fazer as coisas. Rodrigo
\end{abstract}

A partir da provocação desta fala e associada as reflexões de Santos (2019) recorri ao exercício da "pedagogia de ver o grande no pequeno e o histórico no aqui e agora sem perder de vista o pequeno e o aqui e agora” (p. 250). Assim, a partir daí, o que procuro situar nesta categoria são as existências reais, "que pensam parecido...que realmente são grandes potências, são muito competentes no que fazem coletivamente (Aline). Forças comuns que entrelaçam compromisso ético, político e pedagógico em seus ativismos. 
O exercício analítico, torna-se, portanto, afirmar estratégias de viver, saber e ser em modo outro. Compreendendo, que, tal qual fomentado por Walsh (2016),

O decolonial não vem de cima, mas de baixo, das margens, das fronteiras, das pessoas, das comunidades, dos movimentos, dos coletivos que desafiam, interrompem e transgridem as matrizes do poder colonial em suas práticas de ser, atuação, existência, criação e pensamento. $\mathrm{O}$ decolonial neste sentido, não é algo fixo, um status ou condição, nem um ponto de chegada. É um processo dinâmico, sempre em processo de fazer-se e refazer-se dada permanência e capacidade de reconfiguração da colonialidade do poder. É um processo de luta, não só contra mas, ainda ais importante, para - para a possibilidade de um modo de vida outro (WALSH, 2016, p. 72).

À vista disso, os trechos aqui agrupados pretendem sublinhar a multiplicidade de sujeitos e práticas que já existem, mas são pouco visibilizadas. Na expressão de Graciele

Então assim, é muito importante a gente divulgar essas ações, divulgar que o Rafael está com um projeto muito bacana ... Tem a... Acho que a Aline, que tem o projeto 'coleta aí'. Tem a Maria do projeto 'por gentileza'. Se outro jovem vê que realmente aqui na cidade, aqui mesmo na cidade dele tem pessoas que são capazes de mudar a realidade de São Gonçalo, talvez ele se anime também para criar até soluções melhores do que isso que a gente está fazendo agora. Eu acho que essa é a grande missão também: impactar as pessoas. Graciele

Destaca-se nos relatos sobre atores sociais aspectos de amizade, respeito e admiração, especialmente entre os participantes do Projeto Ressuscita São Gonçalo. As juventudes expressam sentimentos de identificação e confiança nos projetos e sonhos uns dos outros.

Eu gosto muito do Rafael e eu sei que ele é uma pessoa muito engajada, de uma maneira muito positiva, eu confio muito no trabalho dele [...] eu senti confiança e sei que ele quer o melhor da cidade também, e a gente vê isso claramente nas atividades que ele está desenvolvendo até agora mesmo nesse período que a gente está vivendo de pandemia. Paola

As pessoas têm medo de fazer, de colocar os dados pessoais em um negócio desse (referindo-se ao questionário do Projeto), tem muita dificuldade ainda, a galera fica com medo. Com um pé atrás. Mas eu acho que é um caminho muito pertinente esse que o Rafael está fazendo. Todas as pessoas são maravilhosas também. Eu conheço a Daniele, eu conheço a Paola e eu acho que essas pessoas têm um brilho nos olhos, são essas pessoas que tem todas condições para mudar essa cidade. Valda

Tem pessoas que são de fazer. A Daniele é braba. É muito de pegar para fazer, de agitar tudo"[...] Rafael teve sempre essa "incomodação". Ele queria ver uma São Gonçalo melhor se desenvolvendo, tendo mudanças significativas [ ...] De tudo que a gente conversou do projeto e na vida, eu acho que essa sempre foi a motivação dele. Foi esse acreditar para mudar as coisas. Ele é uma das pessoas que eu vejo e falo, cara, é apaixonado pela cidade. Helaine 
Tanto nas notas das observações quanto nas narrativas a partir das entrevistas, a paixão pelo território mostra-se unanime entre os entrevistados. Ao longo deste trabalho ser e pertencer anunciaram memórias afetivas, desaprender para reaprender e reinterpretações propositivas. Observa-se "que essas pessoas têm um brilho nos olhos" tanto pelo território quanto por serem gonçalenses. Isto posto, o trecho que destaco a seguir é o relato de Aline sobre suas perspectivas concretizadas na realização do projeto e app “Coletaí". Trata-se de um trecho longo, porém dinâmico sobre compreender as realidades do poder moderno colonial e insurgir em ação.

comecei a fazer, a olhar para a cidade de um outro jeito. E aí ano passado, eu e a Paula, uma outra pessoa que eu conheci através desses jovens, a gente fez um levantamento dos pontos de descarte de recicláveis aqui na cidade. A gente descobriu que todos estavam fechados, simplesmente isso. A gente fez uma planilha, a gente foi ligando para os lugares e aí eles falavam, está fechado, não existe mais, a maioria eram parcerias com a ENEL ${ }^{45}$ e a ENEL falou que não ia fazer mais, não ia pagar mais e ia fechar. E aí a gente ficou muito perplexa e muito chocada, e aí a gente foi lá, não tinha o que fazer a princípio, a gente tentou contato com o pessoal da ENEL, e as portas estavam fechadas. Tinha uma pessoa queridíssima minha, que eu conheci também nesses caminhos assim de sustentabilidade, que era uma jornalista de uma revista lá do Rio, de sustentabilidade, eu conversei com ela e falei, não é possível, isso está acontecendo aqui, fecharam todos os pontos, é uma cidade de 1 milhão de habitantes, não faz sentido não ter pontos de descarte de recicláveis. Aí ela pegou e a gente fez uma matéria sobre isso e chegou no pessoal alto de lá, porque, obviamente, estava expondo que a ENEL tinha fechado tudo. Então a gente conseguiu que o de Alcântara ${ }^{46}$ reabrisse, inclusive a gente fez a cobertura [nas redes sociais]. Conseguimos reabrir o de Alcântara, eu fui lá, conversei com uma moça que estava levando as latinhas de cerveja dela e eu fiquei tipo, nossa, cara, que exemplo. Conversei com ela, ela falou que ela não jogava fora, porque ela sabia que aquilo ali poderia ser reciclado, aí ela aproveitou que estava indo em Alcântara, juntou isso e levou lá e, eventualmente, as pessoas ganham desconto [ na conta de luz]. O meu objetivo com isso acaba sendo simbólico, porque um lugar aberto desse para um milhão de habitantes, por mais que seja em Alcântara, não dá vazão nenhuma, na prática. É simbólico da nossa vontade, que tenha mais iniciativa de sustentabilidade em São Gonçalo [...] Eu sou a louca que fica lá ligando pra Marquise ${ }^{47}$, eu fico vigiando o caminhão de lixo, inclusive já corri várias vezes atrás dele antes de ter lixeira aqui perto de casa. Eu ficava vigiando porque eu sabia o horário. Eu saía correndo e aqui eu tenho que descer uma ladeira para ir para a rua onde ele passa, e eu louca com um saco de lixo, porque eu não queria que meus pais queimassem o lixo, porque era o que a gente fazia quando eu era pequena. Agora a gente está em um momento que as coisas viraram de cabeção para baixo, a gente não pode sair de casa e as coisas também se estreitaram um pouco, então está sendo bem difícil continuar, dada as circunstâncias, mas a esperança continua

45 A ENEL é a empresa de energia ele ética da cidade de São Gonçalo.

46 Alcântara é um dos 91 bairros do município de São Gonçalo. Atualmente Alcântara é considerado o principal polo econômico e comercial da cidade. 47 Marquise Ambiental é a empresa de coleta domiciliar que presta serviço para o município de São Gonçalo. 
aqui... de fazer o que eu posso dentro das possibilidades, para viver em uma cidade mais limpa. Esse é meu sonho.

Além de demonstrar que não se pode subestimar a grandeza dos pequenos atos, o relato de Aline põe atenção a um posicionamento crescente nas novas formas de ativismo das juventudes. No trecho destacado a participante denuncia precariedades e transforma este espaço e tempo em transgressão e insurgência criativa. Os desafios que a participante descreve parecem ter estimulado a emergência de seu pensamento crítico de modo a desnaturalizar e incidir com e para o território. Circunstância que converge com o pensamento de Walsh (2013) sobre o pedagógico e o decolonial. São pontos chamativos que práticas notadas não são externas às realidades, subjetividades e histórias vividas pelas pessoas comuns. Segundo a referida autora "a pedagogia decolonial é parte integrante de suas lutas, perseveranças e persistências de serem humanas (p. 31).

Vale ainda observar que, além de sujeitos e seus engajamentos, foram referenciados espaços e práticas pedagógicas que estariam mobilizando paradigmas outros "não só de resistência, mas mais ainda na construção insurgente e criativa de "muitas outras maneiras" nos âmbitos sociais" (WALSH, 2016, p. 67). Nessa direção, está presente o diálogo com espaços não formais de educação, como a Casa Fluminense e o projeto Ressuscita São Gonçalo.

Entrou gente de praticamente todos os municípios [da região metropolitana]. Cada canto do Rio de Janeiro tem um representante. [...] As pessoas...nossa...um de cada jeito! Cada ano tem um perfil, tanto de pessoas que eles selecionam e também o perfil do curso. Esse curso desse ano é muito voltado para a eleição municipal. Então eles perguntam muito qual o trabalho dos grupos em relação à eleição municipal, o que eles têm feito para contribuir, se tem alguma pessoa ali que trabalha para algum candidato especifico. Então eles procuram pessoas que incidam nessa linha. Esse ano foi a linha eleitoral. A gente ia discutir sobre SUS, sobre economia, mobilidade urbana, então era super amplo o curso... e teve uma procura nesse ano... uma procura muito grande, que eles até falaram que superou todos os anos de procura. Que estava difícil selecionar. Selecionaram muito no que cada pessoa defendia, tanto de município onde mora e o que a pessoa defendia. Pena que está parado, vamos ver... Gisele

Acho que o Ressuscita contribui para a formação de novas lideranças, para as pessoas saberem o que querem contribuir para a cidade em que moram, ou não querem contribuir. Ou às vezes vão se decepcionar, ou às vezes aprender mesmo porque não sabe ainda pesquisar... Então eu acho que o Ressuscita é uma ferramenta pedagógica para formação de novas lideranças. Isso o jovem que é voluntário, né. E para o jovem que não é voluntário, mas que vai acessar alguma informação, dele perceber que existem jovens um pouco mais velhos do que ele, que estão começando esse caminho, então isso pode gerar referências interessantes e ao 
mesmo tempo conseguir encontrar informações que talvez eu, com trinta anos, quando tinha quinze, dezesseis, dezessete, não consegui encontrar. Rodrigo

Tanto o relato de Gisele quanto o relato de Rodrigo evidenciam que as lutas sociais são cenários pedagógicos de aprendizagens, desaprendizagens, reflexão e ação. Também são pontos chamativos o fato de ambas as dinâmicas sublinhadas estarem inseridas no debate para formação de novas lideranças, quiçá outros microuniversos insurgentes.

De acordo com Gisele "esse ano foi a linha eleitoral" nas propostas do curso de políticas públicas da ONG Casa Fluminense. Para situar, o contexto de crise política, financeira e social brasileiro agravado pela pandemia é angustiante. As lideranças nacionais, estaduais e municipais parecem comprometidas com a opressão e deixam perceptíveis seus projetos de extermínio. O que busco alertar é a necessidade de uma reconfiguração da democracia representativa. O que pergunto é: seria essa uma brecha para alargar a participação de lideranças periféricas nos espaços da democracia representativa?

Para finalizar, tudo aqui escrito indica que todo saber tem um fazer e todo fazer tem um saber, uma noção cara a abordagem deste trabalho em perspectiva a interculturalidade crítica. Assim, buscou-se visibilizar formas de pensar e agir distintas a lógica eurocêntrica "permitindo uma nova relação entre conhecimento útil e necessário na luta pela decolonização epistêmica" (OLIVEIRA; CANDAU, 2010, p. 25) conforme as trajetórias investigadas. Vale sublinhar que as brechas que foram destacadas, fossem referidas a sujeitos, espaços ou práticas dos processos formativos dos participantes são alguns exemplos de aberturas ou inícios, como bem ilustra o depoimento de Helaine

É essa coisa do potencial. [...] Eu vejo muita coisa boa em relação a isso, esses potenciais, tanto de força humana, de vontade humana de fazer as coisas, de se importar com a cidade e com outro, quanto dos próprios espaços. [...] tem uma coisa também, acho que de boa parte das gerações anteriores à nossa, que olham para a gente hoje e falam, cara, você fala isso porque você é novo, não vai dar em nada. Isso é muito frustrante. Então ouvir isso de você, da sua pesquisa... tem amigos meus também, amigos dos meus pais que dão força, que dizem que tem que mudar, que tem de fazer. Isso é muito bom. E entender que a gente, todos nós, a minha geração, a sua, a gente vai trabalhar para que as próximas gerações consigam ter acesso a alguma coisa. Também não é a ilusão de achar que vai mudar tudo. Eu tenho muito essa coisa assim, de que não pode ser só por agora. A gente pode querer mudar para uma coisa maior. Mudar para quem vem depois. Para mudar para quem vem depois, a gente precisa fazer coisas agora. Isso é uma coisa que a gente tem que estar lembrando sempre. É difícil, a gente quer ver a mudança, participar da mudança, 
desfrutar da mudança, tem que entender que vale a pena para quem vem depois, para a cidade que fica. Helaine 


\section{Considerações finais}

"Desnaturalizar, questionar e insurgir"

Vera Candau

As considerações aqui tecidas ressaltam a relevância e importância de um campo de pesquisa cada vez mais efervescente pela sua potência pedagógica insurgente. Coube a mim, portanto, enquanto pesquisadora, o esforço de organizar e tornar legível por meio de uma divisão analítica o complexo e rico material empírico acumulado durante o percurso da investigação.

Esta pesquisa buscou compreender processos formativos que constituem a participação social de jovens gonçalenses. Para tanto, o percurso da pesquisa buscou priorizar conhecer, compreender e visibilizar experiências e dinâmicas que estariam favorecendo engajamento e participação social dos/as jovens em seus territórios. A partir das trajetórias e narrativas de jovens lideranças comunitárias do projeto "Ressuscita São Gonçalo", os ativismos evidenciam propósitos de sujeitos que no coletivo buscam transformação social e valorização do território gonçalense. As juventudes sugerem ações nas fissuras sociais locais, comunicando horizontes e estratégias para superação de descasos que subalternizam os territórios periféricos. Algo que na perspectiva do referencial teórico aqui abordado, aponta para "brechas decoloniais" onde alianças se constroem em resistência, transgressão e insurgências para (re) criar e (re)construir o vívido (WALSH, 2016).

O percurso metodológico da investigação favoreceu a compreensão de que as novas formas de participação e ativismo social estão acompanhadas de novas formas de ver e viver no mundo. A partir das observações em campo, pode-se afirmar que as juventudes e suas novas formas de mobilização debatem desde temas da vida cotidiana à conteúdos estritamente políticos. Com isso aponta-se uma questão cara para esta dissertação: o crescente reconhecimento de que processos cotidianos são em suma processos políticos.

Um primeiro aspecto a ser ressaltado é que o tema das juventudes e participação sociopolítica, (re)torna-se emergente. As novas formas de ativismo contribuem com chaves de leitura na afirmação e promoção dos Direitos Humanos, especialmente no contexto histórico da modernidade ocidental, marcadamente excludente. Historicamente, juventude e negociação sociopolítica estão conectadas. 
Especialmente quando reúnem suas insatisfações no propósito de fortalecer a democracia global e construção de novos caminhos para o planeta que tem enfrentado desgaste político, humanitário e geográfico.

Neste contexto, os jovens percebem que mobilizar-se é algo que faz sentido, que influencia e que pode mesmo atemorizar as autoridades. Percebem, ainda, que participando de uma reflexão conjunta logram espaços de direitos e justiça social e, diante das impertinências da administração pública mobilizam, manifestam e protestam chamando a atenção para si, suas vozes e corpos. Assim, exigem estar diante de políticas públicas que assegurem direitos: acesso à educação, cultura, segurança, lazer, autonomia, trabalho e emancipação. De maneira que os processos nos quais se envolvem em suas trajetórias repercutam na vida presente e futura de forma satisfatória. Logo, é possível concluir que o fenômeno do engajamento das juventudes é diversificado e complexo e pode ser apresentado por características que esboçam movimentos que vão além da crítica à realidade.

No que tange especificamente aos jovens do projeto Ressuscita São Gonçalo, é possível destacar alguns aspectos importantes que se sobressaem em suas narrativas e atravessam todo este trabalho investigativo. Dentre eles: aprendizagens no escopo das desigualdades sociais com potencial de ressignificação de ausências em presenças, com destaque a perspectiva afetiva em potentes leituras para a transformação do território; proposições para reconfiguração de representação legislativa local; sujeitos e práticas que se revelam pedagógicas e insurgentes nas arenas do cotidiano. Apesar de desconfianças com o sistema político representativo, representam uma juventude que não rejeita as vias institucionais de representação democrática. Pelo contrário. Os resultados das observações aqui realizadas ilustram juventudes em nova cultura de participação que tem início nas denúncias, mas privilegiam o agir de forma coletiva.

É importante ressaltar que a situação histórica na qual a pesquisa foi realizada permite realçar a presença de atores insurgentes nas comunidades, becos e favelas. A pandemia evidenciou microuniversos insurgentes, assim como os jovens gonçalenses, que viabilizaram assistência, dignidade e resistência em locais que o Estado não projeta alcançar. Emerge deste cenário, os associativismos e conexões dos jovens do Projeto Ressuscita São Gonçalo com outros importantes projetos sociais. Destaca-se no contexto investigado a associação com a ONG Casa Fluminense. A ONG apresenta-se como espaço para a construção coletiva de 
políticas para a promoção de igualdade social e o aprofundamento democrático no Rio de Janeiro. Para tanto, acredita ser preciso amplificar vozes que ecoem pressões políticas junto ao poder público, ou seja, apostar na formação política de jovens lideranças comunitárias, informadas e mobilizadas para a transformação de seus territórios. Fortalecer lutas e resistências que já existem no interior das periferias. Pensar "com" e praticar "a partir" dos territórios periféricos da região metropolitana a (re)construção desses lugares fragmentados pela desigualdade social. Ações e práticas repercutidas em informação e denúncia das desigualdades que configuram a sociedade moderna/colonial. Como podemos observar, aspectos que se relacionam com a perspectiva da interculturalidade crítica defendida por Walsh (2009b), Santos (2010) e Candau (2016). Que fortalecem processos insurgentes de e a partir do protagonismo de sujeitos "Outros".

Na esteira dessas contribuições, a dissertação provocou outras indagações que se apresentam como categorias fundamentais advindas da realidade. Uma delas diz respeito às práticas pedagógicas que atravessam as experiências subjetivas das juventudes em ambientes não formais de educação e são estímulos para novas investigações. Trata-se de estudos em interface com práticas pedagógicas que se mostram insurgentes nos territórios periféricos, adicionados à valorização de saberes e sujeitos que apostam a cada dia e em cada cidade no trabalho de reivindicações e formas de agir localmente, quando também estão intimamente ligadas a situações globais de incertezas e subalternidade. Tanto no campo teórico, quanto no campo prático.

Além de (re)conhecer melhor a cidade e a perspectiva dos jovens sobre o território gonçalense, foi possível identificar sonhos democráticos. Vê-se, pela maneira como apresentam seus engajamentos, com e a partir das experiências que têm na cidade, a emergente dimensão do cotidiano nas modalidades de ação que protagonizam. O que quero provocar com esta representação de ocupação da cidade é um paralelo com dimensões que se apresentam de forma expressiva na fala dos/as jovens entrevistados/as nessa pesquisa. Um tipo de ocupação que não é apenas geográfica, mas uma ocupação que coloca o território periférico numa perspectiva de memórias afetivas e de reinterpretações propositivas. Ou seja, anúncios que elucidam histórias de pertencimento, leituras do passado, do presente e para o futuro como uma forma de luta contra as diversas formas de dominação e negação a que foram submetidos. 
Deste processo, emerge aquilo que chamo neste trabalho de categorias analíticas: perceber-se nas incertezas, encontros com a diversidade, perspectivas em ação e microuniversos insurgentes. Tais categorias são, na verdade, ângulos para indicar processos formativos dos/as jovens participantes visando compreender e visibilizar saberes e fazeres que perpassam passado e presente na constituição das trajetórias dos/as jovens ativistas gonçalenses.

No que tange a perceber-se nas incertezas destaco que, de forma bastante semelhante, os/as entrevistados/as apresentaram memórias tanto de brincadeiras coletivas quanto hábitos familiares que foram redimensionados conforme o território era impactado pelas transformações sociais: desigualdade social cada vez mais acentuada, descaso do Poder Público, ocupação do território pelo tráfico organizado, violência urbana na região, insegurança e medo. Incertezas decorrentes da experiência de implementação de projetos e políticas públicas sem qualquer diálogo com a realidade local.

A partir destes relatos é possível recuperar que, assim como outros municípios periféricos da região metropolitana, a cidade de São Gonçalo, é alcançada mais por equívocos que acertos das políticas de segurança do Estado. Uma espécie de esperança para manutenção do status de cartão postal da capital carioca, mas para o "lado de cá" regulação e invisibilidade. Algo em consonância com a linha abissal ilustrada por Boaventura de Sousa Santos.

No que tange ao tema da política representativa, atravessa o relato dos/as jovens um sentimento semelhante a abandono diante das incertezas que se desdobram na realidade das exclusões sociais. Ao longo das entrevistas os/as jovens compartilhavam percepções subjetivas e objetivas em contextos de desigualdade social presentes na cidade em que residem. Durante as entrevistas muitos temas foram rememorados. Alguns inclusive recentes, por exemplo, quando mencionam o ingresso no Ensino Superior. Dentre as percepções apresentadas, destacam-se as dificuldades de acesso e permanência neste nível de ensino. Questões que até hoje se apresentam como um desafio para as juventudes periféricas, como é o caso dos/das jovens que residem em São Gonçalo.

Outra questão que surge na fala dos jovens entrevistados é a percepção de que padecem historicamente das forças do poder moderno/colonial, o que explica os processos de exclusão vivenciados. Entretanto, suas ações formativas e ativismos sociais indicam dimensões de aprender a questionar, inquirir e amplificar suas 
vozes para a transformação social. Assim, suas experiências e percepções relatadas indicam transformação das ausências em presenças, conforme postula Santos (2002).

No que se refere aos encontros com a diversidade, foi possível perceber ao longo dos relatos que os encontros promovidos pelo coletivo assumem diferentes aspectos sobre a compreensão da diversidade e interrelacionam-se tanto em diferentes sujeitos quanto em diferentes espaços sociais. Evidencia-se, sobretudo, uma diversidade específica dos territórios populares, como ocorre no município gonçalense. Temas como relações étnico-raciais, aceitação da diferença, reações a intolerância e discriminação também emergem nas pautas levantadas pelos seus ativismos e reverberam em suas ações protagonizadas dentro e fora da cidade. Todas essas questões parecem culminar no que chamo de perspectivas em ação e microuniversos insurgentes, onde ficou evidente a pedagogia em desaprendizagens, experiências, reaprendizagens e insurgências.

A partir dessas questões, compartilho que relatos e leituras acessados no desenvolvimento deste trabalho tornaram-se utopia e indicação que a (re)configuração da democracia está ligada a um giro a partir de biografias e pautas Outras nos espaços decisórios. Insurgências políticas e epistêmicas que avançam projetos coletivos de vida. A favela que cuida da favela. Por estas reflexões, espero contribuir para possibilidades de biografias que existem, resistem, (re)existem e propõem a transformação social. Além de ampliar a discussão prática sobre os conhecimentos e a práticas pedagógicas que importam. 


\section{Referências bibliográficas}

ABRAMO, H. W. Considerações sobre a tematização social da juventude no Brasil. Revista Brasileira de Educação, n. 05-06, p. 25-36, 1997.

ALMEIDA, M. I. M. de; TRACY, K. M. de A. Noites Nômades Espaço e subjetividades nas culturas jovens contemporâneas. Rio de Janeiro: Rocco, 2003.

ALMEIDA, S. L. de. Racismo Estrutural. Belo Horizonte: Letramento, 2018.

BALLESTRIN, L. América Latina e o giro decolonial. Revista Brasileira de Ciência Política, n. 11, p. 89-117, 2013.

BOGHOSSIAN, C. O.; MINAYO, M. C. de S. Revisão Sistemática Sobre Juventude e Participação nos Últimos 10 anos. Revista Saúde e Sociedade, v. 18, n. 3, p. 411-423, 2009.

BRASIL. Emenda constitucional no 65, de 13 de julho de 2010. Altera a denominação do Capítulo VII do Título VIII da Constituição Federal e modifica o seu art. 227, para cuidar dos interesses da juventude. Brasília: Diário Oficial da União, 2010

BRASIL. Lei n 8.069, de 13 de julho de 1990. Estatuto da Criança e do Adolescente. Brasília: Diário Oficial da União, 1990

BRASIL. Lei no 12.852, de 5 de agosto de 2013. Estatuto da Juventude. Brasília: Diário Oficial da União, 2013.

BRISEÑO, J. R. Los jóvenes, el pensamiento-otro, y la micro-geopolítica de conocimiento entre generaciones en las Secundarias Comunitarias Indígenas de Oaxaca, México. Education Policy Analysis Archives, v. 26, p. 88, 2018.

CÂMARA, L. Cooperação, grupos identitários e participação democrática no Ensino Médio : o que pensam os professores ? Práxis Educativa, v. 14, n. 007, p. 938-954, 2019.

CANDAU, V. M. Direitos humanos, educação e interculturalidade: As tensões entre igualdade e diferença. Revista Brasileira de Educacao, v. 13, n. 37, p. 45-57, 2008.

CANDAU, V. M. F. Movimentos Sociais e Interculturalidade: desafios para as ações afirmativas. Educação em Foco, v. 19, n. 1, p. 37-57, 2014.

CANDAU, V. M. F. Cotidiano escolar e práticas interculturais. Cadernos de Pesquisa, v. 46, n. 161, p. 802-820, $2016 a$. 
CANDAU, V. M. F. "Ideias-Força" Do Pensamento De Boaventura Sousa Santos E a Educação Intercultural. Educação em Revista, v. 32, n. 1, p. 15-34, 2016b.

CANDAU, V. M. F.; RUSSO, K. INTERCULTURALIDADE E EDUCAÇÃO NA AMÉRICA LATINA: uma construção plural, original e complexa. Revista Diálogo Educacional, [S.I.], v. 10, n. 29, p. 151-169, jul. 2010. ISSN 1981416X.

CARRANO, P. C. R. Identidades culturais juvenis e escolas: arenas de conflitos e possibilidades. In: MOREIRA, Antônio Flávio; CANDAU, Vera Maria (ORGs). Multiculturalismo: diferenças culturais e práticas pedagógicas. Petrópolis, RJ: v. 1p. 182-211 Vozes, 2008.

CARRANO, P. C. R. A participação social e política de jovens no Brasil 1 : considerações sobre estudos recentes. $O$ social em questão, v. 27, p. 8399, 2012.

CARRANO, P. C. R. Jovens em três tempos: mobilizações no Brasil ontem e hoje. Com Ciência (UNICAMP), v. 1, p. 1, 2015.

CARRANO, P. C. R.; MARINHO, A. C.; DE OLIVEIRA, V. N. M. Trajetórias truncadas, trabalho e futuro: Jovens fora de série na escola pública de ensino médio. Educacao e Pesquisa, v. 41, n. Especial, p. 1439-1454, 2015.

CASTELLS, M. A Sociedade em Rede Do Conhecimento à Política. In: Castells, M.; Cardoso, Gustavo. A Sociedade em Rede do Conhecimento à Acção Política; conferência Belém (Por): Imprensa Nacional, p. 435, 2005.

CORROCHANO, M. C.; DOWBOR, M.; JARDIM, F. A. A. Juventudes e participação política no Brasil do século XXI: quais horizontes? Laplage em Revista, v. 4, n. 1, p. 50, 2018.

COSTA, R. P. Participação social: olhares e práticas contemporâneas. CREATIVIDADE, v. 2016, n. 01, 16 jun. 2016.

COUTO JUNIOR, D. R. et al. Jovens em estado de alerta no Facebook: diálogos tecidos em/na rede como estratégia de (re-)existência à regulação das vidas precarizadas. Praxis Educativa, v. 14, n. 3, p. 1210-1229, 2019.

CUNHA, P. R. C. A participação política juvenil e o conhecimento sobre políticas públicas de juventude no Brasil. Revista Segurança Urbana e Juventude, v. 4, n. 1, p. 20, 2011.

DAYRELL, J. O jovem como sujeito social. Revista Brasileira de Educação, n. 24, p. 40-52, 2003.

DUARTE, R. Pesquisa qualitativa: reflexões sobre o trabalho de campo.

Cadernos de Pesquisa, n. 115, p. 139-154, 2002. 
DUARTE, R. Entrevistas em pesquisas qualitativas. Educar em Revista, n. 24, p. 213-225, 2004.

FEIXA, C.; WEISSBÖCK, L. P. Da geração @ a geração blockchain a juventude na era postdigital. Textura - Revista de Educação e Letras, v. 21, n. 47, p. $6-31,2019$.

FERREIRA, V. S. Artes e manhas da entrevista compreensiva. Saude e Sociedade, v. 23, n. 3, p. 118-130, 2014.

FLEURI, R. M. Intercultura e educação. Revista Brasileira de Educação, n. 23, p. 16-35, 2003.

FREIRE, P. A importância do ato de ler. 23. ed. São Paulo: Cortez, (Coleções polêmicas do nosso tempo), 1989.

FREIRE, P. Política e educação: ensaios. $5^{\mathrm{a}}$ ed. ed. São Paulo: Cortez Editora, 2001.

GARCIA, A. D.; MACEDO, E. M.; QUEIRÓS, J. Roteiros de coconstrução de conhecimento, expressão e participação: como pessoas jovens (re)criam cidadania? Praxis Educativa, v. 14, n. 3, p. 1230-1250, 2019.

GIL, A. C. Métodos e técnicas de pesquisa social. São Paulo:Atlas, 2008.

GODOY, A. S. Pesquisa qualitativa: tipos fundamentais. Revista de Administração de Empresas, v. 35, n. 3, p. 20-29, 1995.

GOHN, M. DA G. Jovens na política na atualidade - uma nova cultura de participação. Caderno CRH, v. 31, n. 82, p. 117-133, 2018.

GUIMARÃES, E. Juventude(s) e periferia(s) urbanas. Revista Brasileira de Educação, v. 5-6, p. 199-208, 1997.

IZAÚ, V. R. Insurgências urbanas e direito à cidade na perspectiva de ativistas em belo horizonte. Tese de Doutorado, Belo Horizonte-MG, Universidade Federal de Minas Gerais, 2017.

KAUFMANN, J.-C. A entrevista compreensiva: um guia para pesquisa de campo. Petrópolis, RJ: Editora Vozes; Edugal, 2013.

KILOMBA, G. Memórias da plantação - Episódios de racismo cotidiano. Tras Jess Olivira. $1^{\text {a }}$ ed. Rio de Janeiro: Cobogó, 2019.

KRENAK, A. O amanhã não está à venda. São Paulo: Cia das Letras, 2020.

LACERDA, A.; RAMALHO, L. "Guia de Pesquisa na quarentena: obstáculos e possibilidades para as ciências humanas e sociais em isolamento social". Laboratório de Humanidades Digitais (dhlab) da PUC-Rio e Laboratório de Metodologia (LabMet) do Instituto de Relações Internacionais (IRI)/PUC-Rio (digital), p. 1-27, 2020. 
LEITE, M. Ativismo político e juventude:catracas na escola e na cidade para os jovens mais jovens. Revista da FAEEBA. Educação e Contemporaneidade, v. 26, n. 49, p. 169-185, 2017.

LEITE, M.; ARAÚJO, N. No tempo livre das escolas ocupadas: subversões do presentismo pelo ativismo jovem. Em Aberto, v. 31, n. 101, p. 93-105, 2018.

LEITE, M.; FERREIRA, V. S.; MACHADO, V. F. Dossiê : Jovens e ativismos em (des) construção: socializações e (in) ações políticas. Praxis Educativa, v. 14, n. 3, p. 1004-1006, 2019.

LÓPEZ, L. E. Trece claves para entender la interculturalidad en la educación latinoamericana. In: PRATS, E. (Org.). Multiculturalismo y educación para la equidad. Barcelona: Octaedro-OEI, 2007. p. 13-44.

LOUREIRO, B. Formação política via autoeducação no movimento hiphop : experiências de rappers ativistas no Brasil. Revista Educação, v. 44, p. 1-29, 2019.

LÜDKE, M.; ANDRÉ, M. E. D. A. Pesquisa em Educação Abordagens Qualitativas. São Paulo: EPU, 1986.

MBEMBE, A. Necropolítica. São Paulo: n 1 edições, 2018.

MELUCCI, A. Juventude , tempo e movimentos sociais. Revista Brasileira de Educação, v. 5 e 6, p. 5-14, 1997.

MIGNOLO, W. D. Desobediência Epistêmica: a Opção Descolonial E O Significado De Identidade Em Política. Cadernos de Letras da UFF, v. no 34, p. 287-324, 2008.

MIGNOLO, W. D. Colonialidade: O Lado Mais Escuro Da Modernidade. Revista Brasileira de Ciências Sociais, v. 32, n. 94, p. 01, 2017.

MISCHE, A. De estudantes a cidadãos: redes de jovens e participação política. Revista Brasileira de Educação, n. 05-06, p. 134-150, 1997.

MÜXEL, A. Jovens dos anos noventa. Revista Brasileira de Educação, v. 5-6, p. 151-166, 1997.

OLIVEIRA, L. F. DE; CANDAU, V. M. F. Pedagogia decolonial e educação antirracista e intercultural no Brasil. Educação em Revista, v. 26, n. 1, p. 15-40, 2010.

OLIVEIRA, R. C. DE. O Trabalho do Antropólogo: Olhar, Ouvir , Escrever Roberto Cardoso el e Oliveira. Revista de Antropologia, São Paulo, USP, v. 39, n. 1, 1996.

OLIVEIRA, I. T. M.; LEÃO, G. L. Horizontes juvenis da luta por transporte: o Movimento Tarifa Zero em Belo Horizonte. Praxis Educativa, v. 14, n. 3, p. 1007-1026, 2019. 
QUIJANO, A. Colonialidade, Poder, Globalização e Democracia. Revista Novos Rumos, v. 17, n. 37, p. 4-28, 2002.

QUIJANO, A. Colonialidade do Poder, Eurocentrismo e América Latina. A colonialidade do saber. Eurocentrismo e ciências sociais. Perspectivas latino- americanas, p. 117-142, 2005.

QUIJANO, A. "Bien vivir": entre el "desarrollo" y la des/colonialidad del poder. En Cuestiones y horizontes: la dependencia histórico-cultural a la colonialidad/descolonialidad del poder, Buenos Aires: CLACSO, p. 847-859, 2014.p. 847-859, 2014.

RIBEIRO, D. O conhecimento moderno-ocidental à luz do pensamento decolonial latino- americano : aprender, desaprender e reaprender a partir dos movimentos sociais. Currículo sem Fronteiras, v.18, n 3, pp. 10571076, setembro/dezembro, 2018.

SACAVINO, S. B. Educação descolonizadora e interculturalidade: notas para educadoras e educadores. In: CANDAU, V.M. (Org) Interculturalizar, Descolonizar, Democratizar: uma educação "outra"?. Rio de Janeiro, Editora 7 Letras, 2016.

SAID, S. Pedagogias do Sul e subjetivação política: Os Bachilleratos Populares na Argentina como parte dos "movimentos pedagógicos latinoamericanos". Education Policy Analysis Archives, v. 26, n 26, 2018.

SANTOS, B. DE S. Para uma sociologia das ausências e uma sociologia das emergências. Revista Crítica de Ciências Sociais, n. 63, p. 237-280, 2002.

SANTOS, B. DE S. Para além do pensamento abissal: das linhas globais a uma ecologia de saberes. Novos Estudos - CEBRAP, n. 79, p. 71-94, 2007.

SANTOS, B. DE S. Um discurso sobre as ciências. 5. ed. ed. SÃO PAULO: Cortez, 2008.

SANTOS, B. DE S. O Fim do Império Cognitivo - A afirmação das epistemologias do sul. Autêntica, 2019.

SANTOS, B. DE S. A Cruel Pedagogia do Vírus. Coimbra: Almedina, 2020.

SANTOS, B. DE S.; MESESES, M. P. Epistemologias do Sul. $1^{\text {a }}$ Edição ed. São Paulo: Editora Cortez, 2010.

SPOSITO, M. P. Estudos sobre juventude em educação. Revista Brasileira de Educação, v. 5-6, p. 37-52, 1997.

SPOSITO, M. P. Algumas hipóteses sobre as relações entre movimentos sociais, juventude e educação. Revista Brasileira de Educação, n. 13, p. 73-94, 2000. 
SPOSITO, M. P. Ação coletiva, jovens e engajamento militante. In: Narrativas Juvenis e Espaços Públicos: olhares de pesquisas em educação, mídia e ciências sociais. Editora UFF, p. 97-130, 2014.

SPOSITO, M. P.; ALMEIDA, E. de; CORROCHANO, M. C. Jovens em movimento: mapas plurais, conexões e tendências na configuração das práticas. Educação e Sociedade, v. 41, p. 1-20, 2020.

SPOSITO, M. P.; CARRANO, P. Juventude e políticas públicas no brasil. Políticas públicas de juventud en América Latina: políticas nacionales, p. 1-35, 2003.

SPOSITO, M. P.; CORTI, AP. A pesquisa sobre juventude e os temas emergentes. SPOSITO, Marilia P. Juventude e escolarização (1980/1998). Brasília, MEC/INEP/Comped (Estado do Conhecimento, 7), 2002.

SPOSITO, M. P.; TARÁBOLA, F. D. S. Entre luzes e sombras: O passado imediato e o futuro possível da pesquisa em juventude no Brasil. Revista Brasileira de Educacao, v. 22, n. 71, p. 1-25, 2017.

SPOSITO, M. P.; TARÁBOLA, F. de S. Experiência universitária e afiliação: multiplicidade, tensões e desafios da participação política dos estudantes. Educacao e Sociedade, v. 37, n. 137, p. 1009-1028, 2016.

TEIXEIRA, E.; OLIVEIRA, I. A. de. Cuidados éticos na pesquisa. In: Metodologias e Técnicas de Pesquisa em Educação. $1^{\text {a }}$ ed. Belém: Editora da Universidade Estadual do Pará, p. 9-24, 2010.

WALSH, C. Interculturalidad crítica y pedagogía de-colonial: apuestas (des) de el in-surgir, re-existir y re-vivir. Revista (Entre palabras) v.3, p. 1-29, 2009a.

WALSH, C. Interculturalidade Crítica e Pedagogia Decolonial: in-surgir, reexistir e re-viver. In: CANDAU, V. M. (org) Educação Intercultural na América Latina: entre concepções, tensões e propostas. Rio de Janeiro:Editora 7 letras, 2009b.

WALSH, C. Interculturalidad y (de) colonialidad: Perspectivas críticas y políticas. Visão Global, Joaçaba, v. v. 15, n. n. 1-2, jan./dez., p. 61-74, 2012.

WALSH, C. Pedagogías decoloniales: prácticas insurgentes de resistir, (re)existir y (re)vivir. Tomo I. Quito, Ecuador: Ediciones AbyaYala, 2013.

WALSH, C. Notas pedagógicas a partir das brechas decoloniais. In:CANDAU, V. M. (org) Interculturalizar, descolonizar, democratizar: uma educação "outra"? Rio de Janeiro: Editora 7 letras, 2016. 
WALSH, C.; OLIVEIRA, L. F. DE; CANDAU, V. M. Colonialidade e pedagogia decolonial: Para pensar uma educação outra. Education Policy Analysis Archives, v. 26, n 26, 2018.

ZAGO, N. Do acesso à permanência no ensino superior: percursos de estudantes universitários de camadas populares. Revista Brasileira de Educação, v. 11, n. 32, p. 226-237, 2006. 


\title{
8 Apêndices
}

\subsection{Apêndice 1- Termo de Consentimento Livre e Esclarecido}

\author{
PONTIFÍCIA UNIVERSIDADE CATÓLICA DO RIO DE JANEIRO \\ Programa de Pós-Graduação em Educação \\ TERMO DE CONSENTIMENTO LIVRE E ESCLARECIDO
}

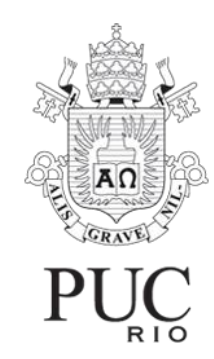

Pesquisa: Jovens ativistas de São Gonçalo: a contribuição dos saberes/fazeres com e para a cidade

Pesquisadores: Mestranda: Erica Nascimento | nascimento.eps@gmail.com | (21) 98607-0243; Orientadora: Vera Maria Ferrão Candau | vmfc@puc-rio.br | (21) $\underline{35271815}$

Justificativa: A pesquisa se justifica diante da necessidade de compreender e visibilizar trajetórias de formação e engajamento de lideranças juvenis. Busca compreender a forma como se organizam as redes de sujeitos e as motivações de seu engajamento.

Objetivos: identificar e compreender os elementos culturais, valores éticos, políticos e estéticos dos saberes que perpassam a formação desses jovens enquanto atores sociais e a participação deles no Projeto Ressuscita São Gonçalo.

Metodologia: Entrevistas áudio-gravadas com os jovens do Projeto Ressuscita São Gonçalo.

Período de armazenamento dos dados coletados: Os registros das informações coletadas na pesquisa serão armazenadas nos arquivos do mestrando por um período 5 (cinco) anos.

Desconfortos e Riscos Possíveis: É possível que algum tipo de constrangimento ocorra ao se abordar temas relacionados à trajetória de vida dos entrevistados. No entanto, todos os procedimentos levarão em conta este risco, respeitando os/as entrevistados/as e garantindo que os relatos sejam apresentados em clima de confiança e sigilo. Será garantido ao longo de todo o processo o respeito à pessoa dos participantes, sua liberdade de expressão e a confidencialidade de suas informações. Em qualquer momento, caso o participante não se sinta à vontade, por menor que seja seu constrangimento, poderá negar-se a responder qualquer questão e/ou retirar-se da pesquisa. A participação nesta pesquisa não traz implicações legais. Os procedimentos adotados obedecem aos Critérios da Ética em Pesquisa com Seres Humanos.

Benefícios: Ao participar da referida pesquisa, o entrevistado não terá nenhum benefício direto. Entretanto, esperamos que este estudo contribua com possíveis processos de formação de novas lideranças juvenis. No término deste estudo os jovens receberão, por email, um documento para acesso aos resultados. 
Confidencialidade: As informações coletadas nesta pesquisa serão estritamente confidenciais, e serão divulgadas apenas em eventos ou publicações científicas, não havendo identificação dos participantes, a não ser entre os responsáveis pelo estudo, sendo assegurado o sigilo sobre sua participação.

$\mathrm{Eu}$,

de maneira livre, esclarecida e voluntária, concordo em participar da pesquisa acima identificada. Estou ciente dos objetivos do estudo, dos procedimentos metodológicos e dos possíveis desconfortos com o tema e das garantias de confidencialidade e da possibilidade de esclarecimentos permanentes sobre os mesmos. Fui informado(a) de que se trata de uma pesquisa de mestrado em andamentos no Programa de Pós-Graduação em Educação da PUC-Rio. Está claro que minha participação é isenta de despesas e que minha imagem e meu nome não serão publicados sem minha prévia autorização por escrito. Estou de acordo com a áudio-gravação da entrevista a ser cedida para fins de registros acadêmicos. Estou ciente de que, em qualquer fase da pesquisa, tenho liberdade de recusar a minha participação ou retirar meu consentimento, sem penalização alguma e sem nenhum prejuízo que me possa ser imputado.

Para maiores informações, a Câmara de Ética em Pesquisa da PUC-Rio (CEPqPUC-Rio), localizada na Rua Marquês de São Vicente, 225 - $2^{\circ}$ andar, Prédio Kennedy - Gávea - Rio de Janeiro - RJ se coloca à disposição para fornecer quaisquer outros esclarecimentos que se fizerem necessários ao assunto em pauta no telefone: (021) 3527-1618.

Nome:

E-mail:

Tel.: / São Gonçalo, de de 2020 .

(assinatura do/a participante)

OBS: Esse termo de Consentimento Livre e Esclarecido será assinado em duas vias, uma do/da participante e outra via para os arquivos da pesquisadora. 


\subsection{Apêndice 2 - Questionário}

Questionário encaminhado aos participantes Projeto Ressuscita São Gonçalo, com objetivo de obter informações sobre os/as jovens envolvidos/as nas atividades do referido projeto.

\section{Dados pessoais:}

Nome:

Email:

Idade:

Gênero:

Como você se identifica étnico-racialmente?

Em qual cidade e estado você nasceu?

Em que bairro mora?

Exerce atividades remunerada?

Se sim, em que cidade?

Quantas pessoas moram na mesma casa que você?

Por favor, descreva brevemente os/as demais moradores/as da residência: codinome, profissão, idade, grau de parentesco.

Qual a renda mensal familiar?

\section{Escolaridade:}

Sobre sua escolaridade, onde cursa/cursou:

Ensino Fundamental

( ) Rede Pública ( ) Rede Privada - com bolsa/desconto ( ) Rede Privada ( ) Não se aplica Ensino Fundamental Incompleto

( ) Rede Pública ( ) Rede Privada - com bolsa/desconto ( ) Rede Privada ( ) Não se aplica Ensino Médio

( ) Rede Pública ( ) Rede Privada - com bolsa/desconto ( ) Rede Privada ( ) Não se aplica Ensino Médio Incompleto

( ) Rede Pública ( ) Rede Privada - com bolsa/desconto ( ) Rede Privada ( ) Não se aplica Ensino Superior

( ) Rede Pública ( ) Rede Privada - com bolsa/desconto ( ) Rede Privada ( ) Não se aplica Ensino Superior Incompleto

( ) Rede Pública ( ) Rede Privada - com bolsa/desconto ( ) Rede Privada ( ) Não se aplica Pós-Graduação

( ) Rede Pública ( ) Rede Privada - com bolsa/desconto ( ) Rede Privada ( ) Não se aplica 
Pós-Graduação Incompleto

( ) Rede Pública ( ) Rede Privada - com bolsa/desconto ( ) Rede Privada ( ) Não se aplica

\section{Sobre sua participação no Projeto Ressuscita São Gonçalo:}

Como você conheceu o Projeto Ressuscita São Gonçalo?

( ) Amigas que fazem parte do Projeto Ressuscita São Gonçalo

( ) Amigos que fazem parte do Projeto Ressuscita São Gonçalo

( ) Ações do Projeto nas ruas da cidade de São Gonçalo

( ) Redes Sociais Virtuais (Facebook, Instagram, outros.)

Que atividades do Projeto Ressuscita São Gonçalo você costuma participar?

*Marque uma ou mais opções

( ) Participo compartilhando conteúdo produzido pelo projeto

( ) Participo dos encontros para planejamento e tomada de decisões

( ) Participo das ações sociais que o projeto organiza e incentiva

Que momento(s) você destaca como importante(s) no Projeto Ressuscita São Gonçalo? Por quê?

Participa de outras iniciativas sociais? Quais?

Na sua opinião, o que a cidade de São Gonçalo mais precisa?

O que te motiva a participar do Projeto Ressuscita São Gonçalo?

Qual o sentido do Projeto Ressuscita São Gonçalo e sua importância para a cidade de São Gonçalo?

O projeto visa aumentar a visibilidade de movimentos sociais na cidade Qual o sentido do Projeto Ressuscita São Gonçalo na sua vida? 


\subsection{Apêndice 3 - Roteiro de observação}

Observação das atividades propostas pelos jovens do projeto "Ressuscita São Gonçalo".

AMBIENTE - descrição do espaço, atividades realizadas

PESSOAS - quantidade, diversidade, dissidências, concordâncias

DINÂMICA - como se organizam, quais seus principais assuntos

RESPONSÁVEL OU LIDERANÇA PELA ATIVIDADE - alguém se destacou? De que forma?

COMO FUI RECEBIDA COMO PESQUISADORA - se disponibilizaram para entrevista? 


\subsection{Apêndice 4 - Roteiro da entrevista com os/as jovens}

Entrevista a ser realizada com os/as jovens que participam das reuniões de planejamento e tomada de decisões do Projeto "Ressuscita São Gonçalo".

\section{Aproximação:}

Conversar sobre o momento atual da vida. O que está fazendo? O que gosta de fazer? Quem são os seus amigos/as?

\section{Trajetória Pessoal:}

Quando você pensa na sua infância, que lembranças vem com maior força na sua cabeça?

E na sua juventude, o que foi e/ou tem sido mais marcante? Que memórias marcam/marcaram esse momento da sua vida?

Para você, o que é ser jovem na cidade de São Gonçalo?

\section{Família:}

O que você recorda de mais importante da sua família? O que era mais gostoso quando você era criança?

Destaca algum momento difícil? Algum momento alegre e de convivência?

\section{Escola:}

Na escola, o que foi mais importante para você? Que memórias você tem da(s) escola(a) em que estudou/estuda? Como foi sua relação com colegas, professores...

Alguma situação vem a sua lembrança? Na relação com os colegas, com os professores...Como você se sentiu?

\section{Trabalho:}

Que experiências de trabalho você tem? Como se sente/sentia com o trabalho que realiza/realizava? Você destaca algum momento de convivência, situação ou pessoas nesses ambientes?

\section{Participação no projeto "Ressuscita São Gonçalo"}

$\mathrm{O}$ que você acha da cidade em que mora? O que você gosta mais? O que menos gosta?

Como surgiu o projeto "Ressuscita São Gonçalo"? Qual a fonte de inspiração?

Como você se envolveu com ele? O que o levou a participar dele? 
O que considera mais importante do projeto? Que conquistas você destaca? E as dificuldades, quais são?

Como o grupo está organizado?

Que estratégias vocês utilizam para alcançar e comunicarem-se com a população Gonçalense? Como isso acontece?

Como são as relações entre os participantes do projeto?

Como se dá a entrada ou saída de pessoas no grupo?

O que sente falta no trabalho com o projeto?

Na sua opinião, qual é a principal contribuição do Ressuscita São Gonçalo para a cidade, para os participantes dele e para você?

O Projeto tem interlocução com outros grupos e/ou movimentos? Na cidade, quais são eles? E em outras cidades? Algum no plano nacional ou internacional? 


\subsection{Apêndice 5 - Roteiro da entrevista com representante da ONG Casa Fluminense}

Entrevista a ser realizada com representante da ONG Casa Fluminense.

\section{Aproximação:}

Conversar sobre o momento atual da vida. O que está fazendo? O que gosta de fazer?

\section{Trajetória Pessoal:}

Me fale um pouco sobre você. Onde você mora? O que você acha da cidade em que mora?

Me fale um pouco sobre sua formação.

Que experiências de trabalho você tem?

Como você conheceu a ONG Casa Fluminense?

Que experiências você tem no trabalho a partir da Casa Fluminense? Como se sente com o trabalho que realiza?

Você destaca algum momento de convivência, situação ou pessoas nesses ambientes?

\section{Trabalho:}

Me fale do trabalho da ONG. Como o trabalho da instituição está organizado? Como é o seu trabalho na ONG? Que atividades você realiza?

Como vocês se conectam com a juventude? Que estratégias vocês lançam mão para conhecê-los, para saber da existência dessas lideranças? Que memórias você tem do trabalho com os/as jovens gonçalenses?

Que conquistas da ONG você destaca? E as dificuldades, quais são?

O que sente falta no trabalho da ONG?

O Projeto tem interlocução com outros grupos e/ou movimentos? Quais são os parceiros da ONG? 


\title{
9 Anexos
}

\subsection{Anexo 1 - Parecer da Comissão de Ética em Pesquisa da PUC-Rio $017 / 2020$}

\author{
Pontifícia Universidade Católica
}

DO RIO DE JANEIRO

CÂMARA DE ÉTICA EM PESQUISA DA PUC-Rio

Parecer da Comissão da Câmara de Ética em Pesquisa da PUC-Rio $017 / 2020$ - Protocolo 38/2020

A Câmara de Ética em Pesquisa da PUC-Rio foi constituida como uma Câmara especifica do Conselho de Ensino e Pesquisa conforme decisão deste órgão colegiado com atribuiçăo de avaliar projetos de pesquisa do ponto de vista de suas implicaçōes éticas.

\section{Identificação:}

Título: "Jovens ativistas de São Gonçalo: A contribuiçăo dos saberes/fazeres com e para a cidade" (Departamento de Educação da PUC-Rio)

Autora: Erica Pereira dos Santos Nascimento (Mestranda do Departamento de Educaçăo da PUC-Rio) Orientadora: Vera Maria Candau (Professora do Departamento de Educaçăo da PUC-Rio)

Apresentação: Pesquisa qualitativa que visa identificar, descrever e compreender o (re) aprender dos jovens, os processos formativos que os constituem como atores sociais e suas motivaçōes para o engajamento político-social no município de Săo Gonçalo. O estudo será desenvolvido junto aos oito jovens (entre 20 e 29 anos de idade) fundadores do Projeto " Ressuscita São Gonçalo" animados pelo lema "Vamos juntos reconstruir a cidade". O projeto é financiado pela organização năo governamental Casa Fluminense. Utilizará como instrumento metodológico entrevista compreensiva. Conta com Casa Fluminense. Utilizará como instrumento metodológico entrevista compreensiva. Conta com
referencial teórico apoiado em literatura referente aos temas de Juventudes, espaços públicos e Interculuralidade, descolonialidade e epistemologia do sul.

Aspectos éticos: O projeto e o Termo de Consentimento Livre e Esclarecido apresentados estão de acordo com os princípios e valores do Marco Referencial, Estatuto e Regimento da Universidade no que se refere às responsabilidades de seu corpo docente e discente. O Termo expöe com clareza os objetivos da pesquisa e os procedimentos a serem seguidos. Garante o sigilo e a confidencialidade dos objetivos da pesquisa e os procedimentos a serem seguidos. Garante o sigilo e a confidencialidade dos penalidade ou constrangimento.

Parecer: Aprovado

Prof. Josétiçardo Bergmann

Presidente do Conselho de Ensino e Pesquisa da PUC-Rio

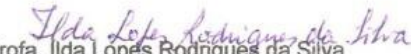

Comissão da Câmara de Ética em Pesquisa da PUC-Rio

Rio de Janeiro, 04 de agosto de 2020

Vice-Reitoria para Assuntos Acadêmicos

Camara de Ética em Pesquisa da PUC-Rio - CEPq/PUC-Rio Rua Marquếs de Såo Vicente, 225 - Gávea - 22453-900 Rua Marqués de Såo Vicente, 225 - Gávea - 22453-900
Rio de Janeiro - RJ - Tel. (021) 3527-1612/3527-1618 e-mail: vraca puc-rio,bs 
9.2 Anexo 2 - Documento Modelo para Pesquisa elaborado pelos/as jovens.

\section{O que é?}

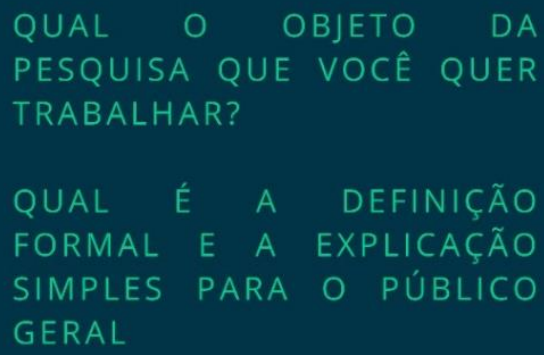

\section{Contexto}

\section{Quais são os problemas?}

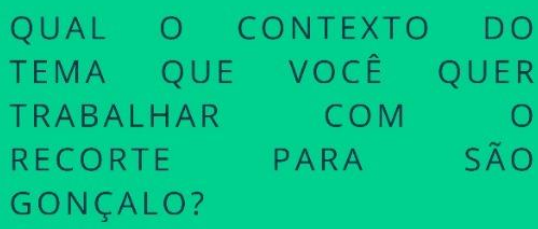

aQUi É IMPORTante COLOCar OS Dados E/OU IMFORMAÇÕES CONFIÁVEIS SOBRE O TEMA, RELACIONANDO AO CONTEXTO

QUAIS SÃO OS PROBLEMAS QUE OS DADOS EIOU INFORMAÇÕES ANALISADOS MOSTRAM? 


\section{Quem se prejudica?}

$\begin{array}{lllr}\text { O QUE } & \text { ESSES } & \text { PROBLEMAS } \\ \text { AFETAM NA } & \text { VIDA } & \text { DA } \\ \text { POPULAÇÃO } & \text { DE } & \text { SÃO } \\ \text { GONÇALO? } & & \end{array}$

SE FOR POSSÍVEL,

APRESENTE AS SOLUÇÕES PARA ESSE PROBLEMA. COMO PODE SER APLICADA? QUEM IRÁ APLICA? É CUSTOSO? QUANTO? QUAIS OUTROS EXEMPLOS MOSTRAM QUE ESSAS SOLUÇÕES PODEM DAR CERTO?

\section{Considerações}

ESSE É UM MOdELO PARA ORIENTAR as PESQUISAS. PODE SER SEGUIDO OU NÃO, MAS ACREDITAMOS QUE É UM RESUMO dOS POHTOS nEGESSÁRIOS, SEM FALTAR INFORMAÇÕES.

PARA GARANTIR A CONFIABILIDADE, OS DADOS OFICIAIS E, SE NãO HOUVER, OS GERADOS, SÃO AS MELHORES FONTES DE IHFORMAÇÃO.

GASO NÃO SEJA POSSÍVEL GAPTAR OU PRODUZIR OS DADOS, RELATOS DE PESSOAS ENVOLVIDAS NA TEMÁtICA PODEM SER APRESENTAdOS tAMBÉm. POREM, E IMPORTANTE QUE TUDO O QUE FOR ESGRITO SEJA MAIS QUE UMA VISÃO PESSOAL, E SIM ALGO SUSTENTATO NA REALIDADE

GASO NÃO SEJA POSSIVEL APRESENTAR SOLUGÕES, UMA CONGLUSÃO, RETOMANDO O QUE FOI DITO Já Ê O SUFICIENTE.

MUITO OBRIGADO, ESTAMOS DISPONIVEIS PARA AJUDAR A MONTAR AS PESQUISAS. SÓ CHAMAR! 